Illinois State University

ISU ReD: Research and eData

Theses and Dissertations

4-1-2019

\title{
Sovereignty in Islamist Political Thought: Continuity and Change
}

Md Mizanur Rahman

Illinois State University, mrahma3@ilstu.edu

Follow this and additional works at: https://ir.library.illinoisstate.edu/etd

Part of the Other International and Area Studies Commons, and the Political Science Commons

\section{Recommended Citation}

Rahman, Md Mizanur, "Sovereignty in Islamist Political Thought: Continuity and Change" (2019). Theses and Dissertations. 1089.

https://ir.library.illinoisstate.edu/etd/1089

This Thesis is brought to you for free and open access by ISU ReD: Research and eData. It has been accepted for inclusion in Theses and Dissertations by an authorized administrator of ISU ReD: Research and eData. For more information, please contact ISUReD@ilstu.edu. 


\section{SOVEREIGNTY IN ISLAMIST POLITICAL THOUGHT: CONTINUITY AND CHANGE}

\section{MIZANUR RAHMAN}

\section{Pages}

Sovereignty is a contested issue in Islamist political thought. Although Islamists practically accepted liberal democracy in various forms across the world, they are yet to solve the normative paradox: how to reconcile Islam’s divine sovereignty to nation-state's popular sovereignty. Normatively, Islamists advocating the divine sovereignty reject any humanconstructed system that intervenes in the divine order and distorts God's divine design. Some Islamists, however, attempt to move away from this interpretation of absolute sovereignty of God and consequently reinterpret Islamic thoughts and practices in a manner that is compatible with the ethos of liberal democracy. This study examines this shifting concept of sovereignty in Sunni Islamist political thought, particularly the transformation from the divine sovereignty to the sovereignty of ummah. Analyzing the theoretical underpinnings of divine sovereignty propagated by Abul A’la Mawdudi and Sayyid Qutb, on the one hand and Islamist sovereignty propagated by Rachid Ghannouchi, on the other the thesis discusses the continuity in modern Islamist thoughts on sovereignty and emergent changes. It demonstrates how Mawdudi and Qutb utilizing the Quranic concept tawhid, the oneness of God, argue that not only the religious authority but all temporal-political authorities are exclusively bestowed to God. The thesis further argues that Ghannouchi's argument for the sovereignty of ummah (community/people) is based on metaphysical understanding of Islam and siyasa shariiyya tradition of Islamic governance. Ghannouchi insists that people own political-temporal authority while keeping 
God's ultimate sovereignty sacred. The thesis, situating the transforming thoughts of Islamist sovereignty vis-à-vis the popular sovereignty, contends that this shift can have a significant normative contribution to the understanding of Islamist thought on democracy.

KEYWORDS: Divine sovereignty, popular sovereignty, Islamist political thought, democracy, ummah 
SOVEREIGNTY IN ISLAMIST POLITICAL THOUGHT: CONTINUITY AND CHANGE

MD MIZANUR RAHMAN

A Thesis Submitted in Partial Fulfillment of the Requirements for the Degree of

MASTER OF SCIENCE

Department of Politics and Government

ILLINOIS STATE UNIVERSITY 
(C) 2019 Md Mizanur Rahman 
SOVEREIGNTY IN ISLAMIST POLITICAL THOUGHT: CONTINUITY AND CHANGE

MD MIZANUR RAHMAN

COMMITTEE MEMBERS:

Ali Riaz, Chair

Kam Shapiro

Yusuf Sarfati 


\section{ACKNOWLEDGMENTS}

I would like to thank my thesis chair Distinguished Professor Ali Riaz for being a nurturing mentor with a perfect balance of guidance and intellectual freedom. My interest in Islamist political thought grew with the conversations with Professor Riaz in many formal and informal occasions. He directed me to sources, including providing numerous materials from his own. Professor Riaz not only taught me politics in eye-opening ways but also taught to be a true teacher and a committed scholar. I learned from him how to be sensitive to humane affairs and react to those with complete commitment and responsibility. This project would not have been possible without his constant encouragement and intellectual engagement. I am indebted to his generosity of time, intellect, and spirit.

I would also like to thank Professor Kam Shapiro for opening my eyes to Western political thought. He taught me how to think theoretically and write my understanding of politics with theoretical nuances. He invested his valuable time for reading thoroughly and giving feedback on drafts of chapters. Professors Kam’s extensive theoretical knowledge would always be an inspiration on the way of my intellectual journey.

Professor Yusuf Sarfati has been very supportive to me not only as a thesis supervisor but also in various capacities throughout my time at ISU. His expertise in Islamism profoundly informed my general understanding as well as theoretical articulations of Islamist politics. Professor Yusuf's critical comments on drafts of my thesis chapters have significantly contributed to shaping my thoughts possible better ways. Apart from academic help, he was very supportive and generous with time in counseling and motivating me at my critical personal crisis.

I am greatly indebted to all great Professors of my department at ISU who taught and motivated me in many capacities. I am especially grateful to Professor T Y Wang, Professor LJ 
Zigerell, Professor Noha Shawki, Professor Nancy Lind, and Professor Michaelene Cox for their support and encouragement. I found the department like a family, generous with all the help I needed.

I appreciate my fellow graduate students' sustenance at ISU who provided an intellectual and social community that fostered the creative process and kept life interesting and fun. I would particularly acknowledge the intellectual and psychological support of Joe Rice, Fati Jamali, Natalie Flex, Nick Mullins, Caroline Kernan, Rashed Moshareff, Zunaid Almamun, and Ryan Arnold.

Above all, I am grateful to my parents, Md. Mafuzur Rahman and Rokeya Begum. I have no words to express my gratitude to them. They have supported me in every way imaginable; without their encouragement, nothing would have been possible. I dedicate this thesis to them as a token of gratitude for unconditional love and support that I have always received from them.

M.M.R 


\section{CONTENTS}

Page

ACKNOWLEDGMENTS I i

CONTENTS

TABLES

CHAPTER I: INTRODUCTION 1

$\begin{array}{ll}\text { The Islamist Paradox } & 1\end{array}$

Major Debates in Islamist Political Thought 3

$\begin{array}{ll}\text { Debates on Islamist Sovereignty } & 8\end{array}$

Why Mawdudi, Qutb, and Ghannouchi? $\quad 12$

$\begin{array}{ll}\text { The Lens } & 14\end{array}$

$\begin{array}{ll}\text { Chapter Outline } & 15\end{array}$

CHAPTER II: LOCATING SOVEREIGNTY IN THE WESTERN AND ISLAMIST

$\begin{array}{ll}\text { POLITICAL THOUGHT } & 19\end{array}$

$\begin{array}{ll}\text { Introduction } & 19\end{array}$

$\begin{array}{ll}\text { What is Sovereignty? } & 20\end{array}$

Sovereignty in Historical Context in Christian and Islamic Traditions 23

Popular Sovereignty in the Western Political Thought 33

$\begin{array}{ll}\text { Conclusion } & 48\end{array}$

CHAPTER III: THE SOVEREIGNTY OF GOD: MAWDUDI AND QUTB'S THEORY OF

$\begin{array}{ll}\text { DIVINE SOVEREIGNTY } & 50\end{array}$

$\begin{array}{ll}\text { Introduction } & 50\end{array}$

Perspectives on Vice-Regency in Islam 51 
The Divine Sovereignty in Islam 58

Mawdudi’s Divine Sovereignty: The Unity of Faith and Politics 60

Qutb’s Divine Sovereignty: A Reaction to the Western Modernity 71

$\begin{array}{ll}\text { Conclusion } & 82\end{array}$

CHAPTER IV: THE SOVEREIGNTY OF UMMAH: GHANNOUCHI'S THEORY OF

$\begin{array}{lc}\text { SOVEREIGNTY } & 84\end{array}$

$\begin{array}{ll}\text { Introduction } & 84\end{array}$

Ghannouchi's Thought in Historical Debates $\quad 85$

The Sovereignty of ummah in Ghannouchi's Thought 88

$\begin{array}{ll}\text { Conclusion } & 107\end{array}$

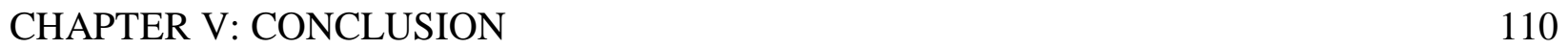

The Shifting Thought on Islamist Sovereignty: A Normative Promise to Democracy 110

$\begin{array}{ll}\text { The Shift } & 111\end{array}$

The Democratic Promise $\quad 116$

$\begin{array}{ll}\text { REFERENCES } & 121\end{array}$

APPENDIX: ENDNOTES 133 


\section{TABLES}

Tables

Page

1. Islamists' shifting positions on sovereignty, nature of the state, shari'a, and secularism 


\section{CHAPTER I: INTRODUCTION}

\section{The Islamist Paradox}

In the present thesis I will examine the shifting concept of sovereignty in Islamist political thought corresponding with the transformation from the divine sovereignty to the sovereignty of ummah. I will attempt to look at the shift by answering the following questions:

1) What is the nature of the contemporary Islamist notion of sovereignty?

2) Has this notion of sovereignty moved away from the articulations of divine sovereignty? If so, has it moved towards the liberal conception of sovereignty, accepting the sovereignty of people or moved in the opposite direction towards insisting the immutability of God's sovereignty? Or it has engendered a new line of thought on sovereignty?

3) What promises, and possibilities, does this shift offer to the democratic development in the Muslim majority countries?

I will analyze the theoretical nuances of divine sovereignty as interpreted by two key figures in modern Sunni ${ }^{1}$ Islamist thought: Abul A'la Mawdudi, the founder of Jamaat-e-Islami in South Asia, and his ideological successor Sayyid Qutb, the dominant Muslim Brotherhood ideologue. I will then investigate the shifting concept of sovereignty - the articulations of the sovereignty of ummah (community/nation), with a critical analysis of the ideas of Rachid Ghannouchi, the cofounder and current president of the Ennahda party of Tunisia.

The thesis aims at contributing to the unresolved contestations on sovereignty in Islamist political thought. It is often called the "Islamist paradox" (Akbarzadeh, 2012). The paradox is that although most Islamist parties in South and Southeast Asia have practically accepted liberal 
democracy ${ }^{2}$ in the modern states, normatively they are yet to reconcile God's sovereignty to the nation-state's popular sovereignty. ${ }^{3}$ It is considered a significant normative barrier to the development of Islamists' democratic theory.

The suppositions of divine sovereignty offer Islamist the leverage to defy the human reasoning-popular sovereignty-based democracy. The assumption is that the fundamental attributes of liberal democracy in modern states those are the upshot of human-rational imagination, undermines God's absolute sovereignty. These Islamists indicate people's sovereignty contradictory to the divine sovereignty. They reject any human-constructed system that intervenes in the divine order and distorts God's divine design. Their vision of Islamic society is radically opposed to the ethos of liberal democracy that derives its legitimacy from the people’s consent, resisting God's absolute authority (Esposito \& Voll, 2001, pp. 22-23). Akbarzadeh argues that Islamists claim to possess the ultimate truth as they believe that their version of the interpretation of Islam is pure, untainted. He asserts that this interpretation leads Islamists to be dismissive to all other interpretations. They behave as if "only they can read God's mind” (Akbarzadeh, 2012, p. 3). They see criticism of Islamism as the criticism of God the distortion of the oneness of Him. Based on this interpretation they maintain that God's absolute sovereignty is uncompromisable in Islam. Some Islamists, on the other hand, attempt to deviate from this exclusive version of God's sovereignty and reinterpret Islam in a way that is compatible with the ethos of liberal democracy. They argue that with God gifted agency, a human being can exercise the political authority that creates a pathway to contend for the sovereignty of ummah in Islam. This fascinating development in Islamist political thought although is an undeniable reality, remains relatively unexplored. 
The extant literature corresponding to sovereignty in Islamist political thought either discusses it as a part of other debates of political Islam such as secularism, nationalism, Islamic state etc., or examines certain Islamist's interpretations of sovereignty. None of the existing researches on sovereignty looks at the shifting nature of sovereignty in Islamist political thought from the previous divine sovereignty theory to the contemporary theory of sovereignty of ummah. The present thesis intends to examine that by investigating the shifting nature of Mawdudi and Qutb’s divine sovereignty to Ghannouchi's sovereignty of ummah. To better understand the shifting thoughts on Islamists sovereignty and locate sovereignty in modern Islamist debates, a brief account of contemporary Islamist debates merits discussion.

\section{Major Debates in Islamist Political Thought}

The fall of the Ottoman Empire and the emergence of nation-states in Muslim majority countries created various doctrinal and pragmatic challenges to the Muslims in the $20^{\text {th }}$ century. The challenge of reconciling God's sovereignty, shari'a, ummah, Caliphate, on the one hand, with secularism, popular sovereignty, nationalism, and other ideas, on the other provoked intense controversies. With these doctrinal and practical challenges spaces for new political thought also emerged in the political landscape of Muslim majority countries. In this context, two contending schools emerged in early $20^{\text {th }}$ century Islamist political thought. The first school carries the inheritance of Muhammad Rashid Rida (1865-1935), a former salafiyya ${ }^{4}$ scholar and an activist

of a conservative-literalist movement, while the second school follows the legacy of Ali 'Abd alRaziq (1888-1966), who accommodated diverse thoughts and ideas.

Although Rida was a part of the salafiyya movement and was enormously influenced by Mohammad Abdhu, he gradually became conservative and literalist in his orientation. He argued that the acceptance of the Western nation-state and ethnicity-based nationalism collapsed Islam's 
normative societal base and practices (Enayat, 1982). He upheld for reinstatement of the Caliphate. ${ }^{5}$ He contends that in Caliphate God's sovereignty must be declared and it should be governed by God's laws. In an Islamic state, for him, the authority of ulama ${ }^{6}$ should be central to interpret revealed texts so that those could be used in the governance of the state through the mechanism of shura (consultation). His Islamic state therefore makes "a direct assault on two vital issues of a modern state: the principle of popular sovereignty, and the possibility of manmade laws" (Enayat, 1982, p. 77). The revival of Islamist politics in the early $20^{\text {th }}$ century was deeply influenced by Rida's conception of Islamic state, Islamic nationalism, and divine sovereignty. The most influential scholars and ideologues of this movement are Hasan al-Banna, Abul A'la Mawdudi, and Syed Qutb, who I categorize as advocates of divine sovereignty. Among them, Banna was more of an activist who founded the Muslim Brotherhood while Mawdudi and Qutb were both Islamist theorists and activists.

In response to the Western modernity, these scholars, engage in several normative and practical contestations. The significant debates concerned the question of sovereignty, secularism, the nature of the state, and the place of shari'a in a modern state. They do not deny the inevitable reality of nation-states, but instead intend to Islamize the principles of a secular state. Islamists accept parliamentary democracy and participate in elections. They paradoxically declare God's sovereignty while rejecting popular sovereignty; they argue for the intermingle religion with politics while refusing secularism; and they advocate for Islamic nationalism while discarding ethnic nationalism. They, rather than democratizing Islamic governing principles, Islamize democracy (Bahlul, 2012 ). All of them believed that politics and religion are inseparable a postulate they draw from the Quranic conception-oneness of God (tawhid). From this concept they also derive the notion of uncompromising divine sovereignty. Contrary to the 
dominant Western political theories, they argue that sovereignty belongs to God alone. Any thought beyond that in Qutb’s word is Jahiliya (ignorance to God).

They proposed an Islamic state where the state should be governed based on revealed texts, consultations (shura), consensus (ijma), and to a limited extent, reasoning (ijtihad). Banna, wanted a state where, as the famous Muslim Brotherhood motto says, “The Qur'an is our constitution, the Prophet is our leader” (Kramer, 2010, p. 99). However, his concentration was on moral and ethical being in an Islamic community. Whereas Banna, following a bottom-up approach, argues that successful social Islamization would transform the state into an Islamic state, Mawdudi and Qutb believed in a top-down approach insisted that the state power should be captured to transform the society into the Islamic direction. Mawdudi claims that an Islamic state is a state of Islamic laws, the sources of which include: the Quran, the practices of Mohammad, the conventions of four rightly guided Caliphs, and the rulings of great jurists (Mawdudi, 1967, pp. 195-210). Although Qutb, do not clearly articulate his concept of an Islamic state, agree with Mawdudi's theory and strengthened it (Qutb, n.d., pp. 87-92; Toth, 2013, pp. 194-206). All of these thinkers unambiguously declare that shari'a should be a codified law in an Islamic state, and the traditional authoritative position of ulama in interpreting texts should be curtailed. They also rejected the concept of Western secularism. For Banna, secularism, which he equated with "licentiousness, foreign domination, Christian mission, materialism, communism, is forbidden" (Kramer, 2010, p. 84) while for Mawdudi, "secularism is a moral and ethical evil that is contrary to the teaching of Islam” (Nasr, 1996, p. 49). Qutb similarly notes, because secularism denies God's absolute sovereignty and permits a human being the authority to make laws, it should be unquestionably abandoned (Toth, 2013). 
The second school of thought mentioned above, led by Razek, contests Rida's argument for the reinstitution of caliphate on two grounds. Razek (2013) argues, firstly, that neither in Quran nor in Hadith, there is anything called caliphate, and secondly, historically, Caliphates were sustained and given legitimacy through coercive means. The subjects did not always voluntarily accept the caliph’s rule in Islamic traditions of governance. Razek argues that they were forced to comply with caliphs' state of governance in many means. Caliphates were never valued for their inherent merit. Razek further maintains that in Islam no specified model of Islamic governance exists, leading him to argue further that any form of governance that does not contradict to the essential modalities of Islam is acceptable. He also wrote that Islam and politics are not inseparable and there is a space in Islam to accommodate the tenets of the popular sovereignty (Razek, 2013, pp. 38-40). Razek’s thought opened a new possibility of experimenting with different models of governance in Islam. Nevertheless, this did not get a positive reception in Islamist thought as Razek had to face many hostilities including being dismissed from his position as a scholar and jurist at Al-azhar university in Egypt. Razek’s thesis, although remained marginal, started to be revived at the end of the $20^{\text {th }}$ century, particularly with the writings of Rachid Ghannouchi.

Ghannouchi departs from his predecessors like Banna, Mawdudi and Qutb in many ways. He argues for the sovereignty of ummah, with the emphasis that religion and politics are two separate entities in Islam. In opposition to an Islamic state thesis, he argues for a democratic civil state (Ghannouchi, 2018, pp. 20-25). The objective of the civil state is to ensure human welfare, social justice, an exercise of free will and the establishment of human rights. The government would be formed based on consensus via free and fair election. Gender equality would be guaranteed, and freedom of belief and conscience would be safeguarded. In the state Ghannouchi 
envisions, Shari'a would not be encoded as the positive law of the state, but instead would work as a moral guide of governance. Moreover, unlike his predecessors, he does not reject western secularism in its entirety.

\begin{tabular}{|c|c|c|c|c|c|}
\hline \multirow[t]{2}{*}{$\begin{array}{l}\text { Issues of } \\
\text { contestation }\end{array}$} & \multicolumn{4}{|c|}{$\begin{array}{c}\text { Islamists } \\
\text { advocating the divine sovereignty }\end{array}$} & \multirow{2}{*}{$\begin{array}{c}\text { Islamist } \\
\text { advocating the } \\
\text { sovereignty of } \\
\text { ummah } \\
\text { Rachid } \\
\text { Ghannouchi }\end{array}$} \\
\hline & $\begin{array}{l}\text { Overlapping } \\
\text { principles }\end{array}$ & $\begin{array}{l}\text { Hasan al- } \\
\text { Banna }\end{array}$ & $\begin{array}{l}\text { Abul ala } \\
\text { Mawdudi }\end{array}$ & Syed Qutb & \\
\hline Sovereignty & $\begin{array}{l}\text { believe in the } \\
\text { divine } \\
\text { sovereignty, } \\
\text { the } \\
\text { sovereignty of } \\
\text { God }\end{array}$ & $\begin{array}{l}\text { subscribes for } \\
\text { the } \\
\text { sovereignty of } \\
\text { God. Banna, } \\
\text { however, did } \\
\text { not theorize it }\end{array}$ & $\begin{array}{l}\text { Mawdudi } \\
\text { theorizes the } \\
\text { divine } \\
\text { sovereignty }\end{array}$ & $\begin{array}{l}\text { Qutb } \\
\text { accepts } \\
\text { divine } \\
\text { sovereignty } \\
\text { and more } \\
\text { vigorously } \\
\text { argues for } \\
\text { it }\end{array}$ & $\begin{array}{l}\text { argues for the } \\
\text { sovereignty of } \\
\text { ummah }\end{array}$ \\
\hline $\begin{array}{l}\text { Nature of } \\
\text { state }\end{array}$ & $\begin{array}{l}\text { an Islamic } \\
\text { state to } \\
\text { establish } \\
\text { based on } \\
\text { shari'a law }\end{array}$ & $\begin{array}{l}\text { stressed on } \\
\text { social } \\
\text { Islamization } \\
\text { that would } \\
\text { ultimately } \\
\text { culminate into } \\
\text { an Islamic } \\
\text { state }\end{array}$ & $\begin{array}{l}\text { theorized } \\
\text { and acted } \\
\text { for } \\
\text { establishing } \\
\text { an Islamic } \\
\text { state }\end{array}$ & $\begin{array}{l}\text { theorized } \\
\text { and acted } \\
\text { for } \\
\text { establishing } \\
\text { an Islamic } \\
\text { state }\end{array}$ & $\begin{array}{l}\text { argues for a civil } \\
\text { state }^{7} \text { defying } \\
\text { the concept of an } \\
\text { Islamic state } \\
\text { entirely }\end{array}$ \\
\hline Secularism & $\begin{array}{l}\text { any form of } \\
\text { secularism is } \\
\text { outrightly } \\
\text { rejected }\end{array}$ & $\begin{array}{l}\text { rejects } \\
\text { secularism }\end{array}$ & $\begin{array}{l}\text { rejects } \\
\text { secularism }\end{array}$ & $\begin{array}{l}\text { rejects } \\
\text { secularism }\end{array}$ & $\begin{array}{l}\text { accepts } \\
\text { American model } \\
\text { of secularism }^{8}\end{array}$ \\
\hline Shari'a & $\begin{array}{l}\text { shari'a as a } \\
\text { coded law } \\
\text { and an } \\
\text { Islamic state } \\
\text { must execute } \\
\text { those }\end{array}$ & $\begin{array}{l}\text { shari'a as a } \\
\text { coded law and } \\
\text { an Islamic } \\
\text { state must } \\
\text { execute those }\end{array}$ & $\begin{array}{l}\text { shari'a as a } \\
\text { coded law } \\
\text { and an } \\
\text { Islamic state } \\
\text { must } \\
\text { execute } \\
\text { those }\end{array}$ & $\begin{array}{l}\text { shari'a as a } \\
\text { coded law } \\
\text { and an } \\
\text { Islamic } \\
\text { state must } \\
\text { execute } \\
\text { those }\end{array}$ & $\begin{array}{l}\text { shari'a as a } \\
\text { moral guide, not } \\
\text { a codified } \\
\text { positive law }\end{array}$ \\
\hline
\end{tabular}

Table 1: Islamists' shifting positions on sovereignty, nature of the state, shari'a, and secularism 
Ghannouchi harshly criticizes the French version of secularism and its adaptation in postcolonial Tunisian state, but Ghannouchi accepts the American model of secularism where state remains neutral towards the religious affairs and guarantees the peaceful practices of all religions. For him, although religion remains formally separated from the state, it would stay in the public sphere and politics would be informed by the religious ethos (Ghannouchi, 2013). Stepan (2012) defines this Tunisian case of secularism as “Twin Tolerations” where on the one hand the state tolerates the citizens free expression of religious views and values and accepts their participation in politics, while on the other hand, religious citizens grant "democratically elected officials the freedom to legislate and govern without having to confront denials of their authority based on religious claims—-such as the claim that 'Only God, not man, can make laws'”(Stepan, 2012, p. 89). Among these major contestations in contemporary Islamism, the debates on sovereignty became intense. Therefore, the contemporary contestations on Islamist sovereignty merit further illustration.

\section{Debates on Islamist Sovereignty}

The debates and contestations on sovereignty in Islam are not an entirely new phenomenon. Mohammad Asad (1961, pp. 37-42), a contemporary of Mawdudi and Qutb, argues for divine sovereignty. He directly rejects any possibility of the sovereignty of people. For him, "people once accept Islam as a divine ordinance, there can be no question of their being endowed with sovereignty in their own right” (Asad, 1961, p. 38). Asad, like Mawdudi and Qutb, argues that "the real source of all sovereignty is the will of God as expressed in the ordinances of shari'a" (Asad, 1961, p. 39). He also abandons the fundamental ground explored by the advocates of popular sovereignty in Islam that the Islamic tradition is abound with the practices of temporal governance. For him, those practices are aberration from general Islamic 
tradition of governance. In Asad's words: “whenever we speak of the 'will of the people' in the context of Islamic political thought, we should be careful...we should not substitute for the unIslamic autocracy of our past centuries the equally un-Islamic concept of unrestricted sovereignty on the part of the community as a whole” (Asad, 1961, p. 38). In contrast, Ahmad (1958) demonstrates that classical Islamic thinkers like Al-Farabi, Ar-Rabi and Ibn Khaldun, described the presence of an Islamic society where a superior man would govern it. Ahmed contends that these Islamic scholars advocated for a kind of Hobbesian supreme ruler and argued for a sovereignty that is close to theoretical underpinnings of the popular sovereignty. For Ahmed, they imagined sovereignty the following way:

"Ruler should be absolutely independent of all limitations or restraints from any other human being; he is not dependent on any one in any way and is not directed, controlled or ruled over by any other man; he achieves all knowledge and perfection by himself; and he is free to take any action to achieve goodness without any check, limit or hindrance from any other man and there is none to reject his actions” (Ahmad, 1958, p. 144).

Ahmed, however, argues that this take on sovereignty is contrary to Islamic conception of sovereignty where real sovereignty belongs to Allah. People, however, can exercise only the right of subservient legislation in the new contexts; they cannot change the fundamental law. Furthermore, the emergence of Pakistan and its constitutional contestations triggered an intense debate on sovereignty in academia. Mawdudi and other scholars championed that the state must declare the divine sovereignty in the constitution while modernists, like Quraishi and Rahman, proposed the opposite. Ahmad (1965) describes that divine sovereignty perceived by Islamists with a notion that God's will that exposed through revealed laws must be executed to establish an Islamic state. Some of the divine sovereignty advocates, on the other hand, saw it from a metaphysical viewpoint. In this exposition, for Ahmad, God is the sovereign of the entire universe as a general moral precept. In this sense, sovereignty belongs to God in both Muslim 
and non-Muslim states in general, but people could manage the temporal affairs (Ahmad, 1965). Famous Urdu poet and scholar Mohammad Iqbal (1965) accepts the divine sovereignty arguing that there is no way to deny God's sovereignty in Islam, but that does not defy human's rational interpretations of temporal affairs, he argues. Iqbal's conception of divine sovereignty, like Mawdudi's ${ }^{9}$, is derived from the doctrine of tawhid that imparts God's oneness of spiritual significance that, for Iqbal is the key determining factor of Islamic sovereignty and polity. In his words: "Islam, as a polity, is only a practical means of making this principle a living factor in the intellectual and emotional life of mankind” (Iqbal, 1965, p. 147). Iqbal, however, argues that divine sovereignty does not curb the human freedom in navigating worldly affairs. For him, God's sovereignty, in fact, safeguards from the state from the errors of human rational judgements.

In contrast, modernist scholar Qureshi (1976) rejects both the literate and metaphysical understanding of divine sovereignty arguing that divine sovereignty is contradictory to the ethos of a modern state. Qureshi's point is that through five times prayer, the individual submits to God and declares His ultimate sovereignty. He argues that God's ultimate sovereignty is not jeopardized by the acceptance of people’s sovereignty on political matters. With a God-given free-rational agency, the way people manage political affairs is not a challenge to God's ultimate sovereignty, but that could be seen as a praxis of God's sovereignty. Qureshi comments:

"It is in the very nature of the freedom given by his Creator to man that he should be free to act in accordance with his beliefs and convictions. If the people of Pakistan-God forbid-stray from the path of the Truth, the sovereignty of God will not cease, but the authority of the people will direct that life in the country in entirely different channels. In a worldly sense, therefore, the people of Pakistan possess at present the final authority even to decide whether they shall be Muslims” (Qureshi, 1976, p. 111). 
Similarly, Rahman (1970) argues that the inclusion of God's sovereignty in the constitution of Pakistan engendered considerable ambiguity. People who rallied for it, had barely any idea on the governance of a modern state. Rahman claims that maintaining of divine sovereignty is practically impossible and it is contradictory to the fundamental ethos of the constitution of a modern state like Pakistan. He writes:

"when the Constitution of Pakistan talks about the Sovereignty of God, it commits sheer confusion under the impact of the revivalists and the rightists in general who had little idea of the modern concept of political sovereignty. When it enunciates the principles of 'Islamic social justice' and 'freedom, equality and tolerance in accordance with the teaching of Islam,' such statements are Janus- faced” (Rahman, 1970, p. 282).

Apart from these debates, the new wave of discussion on Islamist sovereignty emerged in the early 1980s. This wave is either the byproduct of the new debate on compatibility/incompatibility between Islam and liberal democracy or the critical engagement with secularism/modernity. While scholars argue that Islam and democracy are perfectly compatible, they mention that Islamist notion of divine sovereignty poses a doctrinal challenge to the democratization of Muslim majority countries (Soroush, 2000; Esposito and Voll, 1996; Hashmi, 2009; Khan, 2006; Fadl, 2004). However, none of these scholarships discusses Islamist sovereignty as the central point of significance. As the part of modernity/secularism debate, Euben (1999) discusses Qutb’s insistence on divine sovereignty to reject western modernity while Agrama (2012), refers to the underlying tension between the shari'a law and state sovereignty. Neither Euben nor Agrama, however, engages with the theoretical debates of Islamist sovereignty.

Islamist sovereignty debate has gradually started to get more theoretical-scholarly attention. Khatb’s $(2002,2006)$ seminal investigation of Qutb's concept of Hakimiyya where he sheds light on the etymological and definitional facets of sovereignty in Islam with an account of 
Qutb's making of divine sovereignty in reaction to the popular sovereignty. Similarly, Pasha $(2013,2018)$ demonstrates how Qutb’s understanding of theological sovereignty informs his conception of sovereignty in a political sense, and its implication to the contemporary international relations debates. Moreover, Zaman's (2015) contribution to the discussion is noteworthy as he discusses the origin and influence of Mawdudi and Qutb’s divine sovereignty arguing that these Islamist sovereignties should be determined as modern as opposed to their conventional parochial understanding. The most comprehensive and nuanced examination of Islamist sovereignty come from the series of essays written by Andrew March (2013, 2015a, 2010). He analyzes the genealogy of sovereignty in Islamic thought, Islamist ideologues’ interpretations of sovereignty, with an emphasize on Ghannouchi's ideas on the topic. He locates those to the conceptualizations of their counterparts in the Western liberal tradition. However, none of the extant literature in the field examines the transforming interpretations of Islamist thought on sovereignty. The present thesis wishes to contribute to this lacuna of literature and attempts to examine the alternative narratives emerged. It does that by investigating the theoretical underpinnings of three Islamist scholars-Mawdudi, Qutb, and Ghannouchi.

\section{Why Mawdudi, Qutb, and Ghannouchi?}

The choice of these scholars is driven by both theoretical and practical concerns. The divine sovereignty approach is theorized and popularized, at least after the mid- $20^{\text {th }}$ century political context, by the writings of Mawdudi and Qutb. They are not only widely read and discussed, but also have influenced Islamist ideologues and political parties with capacity to mobilize citizens in various Muslim majority countries. Mawdudi's contribution lies in initiating a process of change marked by Islamic ideas that immediately proliferated across the world. Hassan (2003) offers a detailed account of how his ideas and activism spread not only in South 
Asian countries, but in Southeast Asia, particularly in Malaysia and Indonesia while Osman's (2003) research demonstrates Mawdudi's influence in Arabic speaking countries. Osman argues that Mawdudi's thoughts overlapping with the ideas of Hasan al-Banna were instrumental in establishing Muslim Brotherhood in Egypt. Consequently, Brotherhood activists and the organizations emerged with Brotherhood-inspired ideologies in the Middle East and Africa gradually embraced Mawdudian thoughts and activism. Among them, Osman states, Qutb was influenced the most by Mawdudi's ideas and activisms. Both Mawdudi and Qutb’s ideas, he further claims, established the foundation of Islamist revivalist thoughts and movements in the $20^{\text {th }}$ century ${ }^{10}$ (Osman, 2003).

Conversely, Ghannouchi's writings are considered as pathbreaking in revisiting the Islamists conceptions and have immensely influenced modern Islamist thought on sovereignty. He not only argues for the sovereignty of the ummah, but also quite convincingly insists for a civil state with Islamic democracy and a separation of religion from politics, among other things. As a prolific writer both in Arabic and English, he has drawn attention of both policy makers and researchers across the world. His line of thought is regarded as the most influencial and innovative in contemporary Islamist political thought (March, 2015; March, 2013; Jawad, 2013; Hamid \& McCants, 2017; Tamimi, 2001, 2007). Moreover, the peaceful democratic transition in Tunisia during the regime of Ennahda, where Ghannouchi has an instrumental role, is considered the most successful case in the post- Arab spring Middle Eastern politics (Hamid and McCants, 2017; Hamid, 2016). Ghannouchi’s Ennahda party, accordingly, emerged as the vanguard among the contemporary Islamist parties with its attempt to accept liberal democracy with an "Islamic reference” (Wolf, 2017). 


\section{The Lens}

I investigate the selected ideologues’ thought on sovereignty by the lens of Comparative Political Theory (CPT). CPT assumes an understanding of political theory that is defined by particular questions instead of certain answers, and methodological rigor (Euben, 1999). It envisions "a political inquiry which, in a sustained fashion, reflects upon the status and meaning of political life no longer in a restricted geographical setting but in the global” (Dallmayr, 1997, p. 421). It goes beyond the comparative politics subfield's rigorous empirical-descriptive research methodologies and attempts to break the established hierarchy in the study of political thought where Western thoughts are placed over the “non-western” thoughts (Dallmayr, 1997). The objective of the present research similarly is not to analyze Islamists' concept of sovereignty on the scale of the Western liberal thoughts, prioritizing the latter over the former, but rather to assess the shift of thought in the Islamist tradition on its own merits. It does not see the Islamist thoughts from the frame of binarization, namely, secular-religious, and liberal-conservative etc. Freeden and Vincent (2013) are correct when they mention that in the exploration of CPT, the dichotomies and binarizations of comparisons such as colonial/subaltern, religious/secular, oriental/occidental and the like should not be entertained. These binary classifications place ideas hierarchically that is counter-productive in generating inclusive theories.

The present research is largely informed by the methodological approach (CPT) of Euben’s significant work Enemy in the Mirror. Euben contests the understanding of the Western political thought on rationalism arguing that rationalism could be understood in diverse manners and contexts. For her, Qutb’s ideas are rational in his own way while those are determined as “fundamentalist” in the Western narratives of rational standard. Euben contends that “'better' understandings of Islamic fundamentalism are ones that begin by attending to the inherent power 
of the ideas themselves and hence, the relevance of political actor's normative commitments to explanation” (Euben, 1999, p. 25). Such an understanding could be accomplished by, as she comments, “dialogic method of interpretation,” what she determines as "an approach to studying political phenomena that engages the participants' ideas on their own terms, or at least on as close to their own terms as is possible for an interpreter whose position is exterior to the worldview of the subject” (Euben, 1999, pp. 12-13). Euben offers a fruitful parallel between Qutb’s critique of post-Enlightenment rationalism and critiques of contemporary Western political thought such as Hannah Arendt, Charles Taylor and Alasdair MacIntyre, arguing that such cross-cultural comparisons "are transformative for they provide a perspective from which to see parallels and comparisons that narrower conceptions of political theory occlude” (Euben, 1999, p. 123).

Similar to Euben’s thesis I examine Mawdudi, Qutb and Ghannouchi’s thoughts on sovereignty on their own terms. I take some features such as location of the sovereign, the relation of rulers and ruled, the sources of rulers' legitimacy of popular sovereignty from the ideas of Jean Bodin, Thomas Hobbes, John Locke, and Jean Jacques Rousseau, and attempt to situate them in the thoughts of the selected Islamists ideologues. I, however, by no means hierarchically place the facets of popular sovereignty over the intricacies of Islamists’ sovereignty. My attempt rather is to understand the Islamists’ sovereignty in light of the inherent power of Islamists’ ideas in the context of their backgrounds and traditions.

\section{Chapter Outline}

With introductory chapter offering a background of the contemporary Islamist debate and locating the paradox of sovereignty within that, I divided the thesis into three major chapters and a concluding chapter. In chapter one, I locate sovereignty in the history of the Western and 
Islamist political thought. I illustrate how the concept of popular sovereignty evolved through several transformations in the context of European history of Christian Reformation, the separation of Church and state, and the rise of nation states. I further show how the ultimate sovereignty in this tradition shifted from God to the king, and then from king to people. On the other hand, I demonstrate that such shift of sovereignty from God to people did not happen in Islamic tradition. Instead, historically, the debate in Islamic tradition remained limited to the contentions whether religion and politics in Islam could be separated. In this chapter, I identify facets of popular sovereignty pertinent to the topic of the current thesis, from the writings of four major theorists: Jean Bodin, Thomas Hobbes, John Locke, and Jean-Jacques Rousseau, including the location of sovereignty, the sources of ruling legitimacy, and the basis of relations between rulers and ruled. The discussion of Bodin, Hobbes, Locke and Roussseau does not intends to summarize their extensive works or critique their positions on these issues, but only frame a background for locating the nature of Islamist sovereignty vis-à-vis the theoretical intricacies of popular sovereignty.

In chapter two, I focus on the divine sovereignty theory articulated by Mawdudi and Qutb. I divided it into three sections. In the first section, I discuss the prevailing interpretations and contestations on the concept Khalifa, the viceregency in Islamist political thought. Among them, I find that a certain interpretation of the concept - the viceregency of ummah, got prioritized in the modern Islamists discourse although in different manners and contexts. I demonstrate how Mawdudi, Qutb and Ghannouchi interpret the viceregency of ummah, and hint its linkage to their thought on sovereignty. In the second section, I discuss the divine sovereignty thesis of both Mawdudi and Qutb. I show how tawhid - the unity of God, the theological sovereignty informs the political sovereignty of both the ideologues. I also discuss how rulers 
and ruled relations, individual agency, and the issue of shari'a are articulated in the theorizations of Mawdudi and Qutb. I look at how divine sovereignty is considered as the antithesis to the post-enlightenment inspired rational thought that is particularly found in Qutb's theory of divine sovereignty.

In chapter three, I analyze Ghannouchi's thought on sovereignty. I divide the chapter into three sections. In the first section, I outline Ghannouchi's historical legacy on the debates of religion and politics separability and the viceregency in Islam. I show how Ghannouchi's positions in these cases inform his take on sovereignty. In the second section, I demonstrate how drawing from the historical development of Islam, Ghannouchi unambiguously declares the sovereignty of ummah. I identify his differences with the proponents of divine sovereignty in the Islamic tradition on the one hand, and of popular sovereignty in the Western tradition, on the other. In this section, I also show the similarities of Ghannouchi's thought with the contentions of both divine and popular sovereignty. I particularly concentrate on his thought on the location of sovereignty, the social contract creating the relationship between the rulers and ruled, the mechanism of shura, and the place of shari'a in his articulation of sovereignty. In this chapter, however, I also indicate the practical challenges to Ghannouchi's conceptualization of sovereignty.

In conclusion, I summarize the major arguments of the advocates of both divine sovereignty and the sovereignty of ummah explicated throughout the thesis. I articulate what normative contribution the shifting notion of sovereignty has on the larger debates of Islamist political thought. I also ask if this normative transformation of Islamist sovereignty brings any democratic promise in Muslim majority countries. I argue that the shift has a significant 
normative contribution to the democratic understanding in Muslim majority countries that emerges within Islamist political thought. 


\section{CHAPTER II: LOCATING SOVEREIGNTY IN THE WESTERN AND ISLAMIST POLITICAL THOUGHT}

\section{Introduction}

The present chapter focuses on the historical trajectories of the rise of popular sovereignty in the Western and Islamist political thought. It is divided into three sections. The first section illustrates the definitional complexities and categories of sovereignty. It affirms that sovereignty is defined as the ultimate domestic or internal authority of a ruling political body in this thesis. The second section locates the historical rise of popular sovereignty in the Western political thought and Islamist political tradition's debate if politics is separable from Islam. It shows how popular sovereignty evolved through several transformations in the context of European history of Christian Reformation, the separation of Church and state, and the rise of nation states. The ultimate sovereignty in this tradition shifted from God to the king, and then from king to people. On the other hand, it argues that in Islamist political thought, theoretically the historical debates on sovereignty remained limited to the contestations on the separability and inseparability of religion and politics. The section contends that although the history of Islamist politics has addressed the practical intricacies of religion's separation from politics, it was not popularized because the rulers used to harness their legitimacy to rule from the inseparability of Islam and politics. It further adds that this separability and inseparability debates significantly inform the modern Islamist political thought on sovereignty.

The final section elucidates the theoretical debates on the emergence of popular sovereignty in the writings of four major theorists: Jean Bodin, Thomas Hobbes, John Locke, and Jean-Jacques Rousseau. Instead of exploring the whole range of arguments on popular 
sovereignty, it highlights only a few selective aspects pertinent to the topic of the current thesis. It examines the diverse interpretations of sovereignty, the sources of the sovereign's legitimacy, and basis of relations between the rulers and the ruled explored in the writings of the selected theorists on sovereignty.

\section{What is Sovereignty?}

The term sovereignty denotes a complex idea that defies a concise definition. The standard dictionary definition reads: "Supremacy in respect to power, domination or rank; supreme domination, authority or rule." ${ }^{11}$ There are diverse debates on which supreme authority is to be determined as the ultimate sovereign. This definitional and theoretical debates on sovereignty are not contemporary. The elements of the theory of sovereignty are found in the literature of the classical Greek political philosophies and the classic body of the Roman Law. However, it was not theorized until the 16th century. The process of the theorization of sovereignty started with the writings of Thomas Aquinas who under the spell of Aristotle's works, underscored that the supreme power arose from a purely human foundation. Aquinas believed that the authority of the Pope came from God while the authority of the Emperor derived from the consent of the people, and the governance of the Empire was a synchronized function of both authorities (Merriam, 1968).

However, the first systematic discussions on the nature of sovereignty can be found in the works of Jean Bodin. His experience in France which was transforming from the last stage of feudalism, through the disruption of civil war, into a centralized state, led him to argue for a state which places its interest above all considerations (Merriam, 1968). Bodin defines sovereignty as "the absolute and perpetual power over citizens and subjects in a Commonwealth" (Bodin, 1955, p. 25). For him, it is first and foremost absolute, in that it is completely free from the restraints of 
law and is not subject to any conditions or confinements. Bodin's contemporary Grotius defines sovereignty as "that power whose acts are not subject to the control of another so that they made void by the act of any other human will” (Merriam, 1968, p. 21). The Englishman, Thomas Hobbes constructed a more comprehensive argument for absolute sovereignty. To Hobbes, the sovereign is "the mortal God who may use the strength and means of them all as he shall think expedient, for their peace and common defense” (Hobbes, 1952, p. 132). John Locke argues for a sovereign political community established by a fundamental law which runs the supreme government. For him, a sovereign political entity authorized by the general people of the community who surrender their natural rights is necessary for the common good (Merriam, 1968). Rousseau, on the other hand, defines sovereignty as the general will of people where sovereignty is inalienable and indivisible-legislative authority that cannot be transferred to any person or body less than the whole and one part of the assembly cannot be charged with some matters of legislation and other parts with others (Rousseau, 1997, pp. 57-58).

In the contemporary debates of political science and international relations, sovereignty is classified into diverse categories, i.e., legal and political sovereignty, domestic and international sovereignty. Stephen D. Krasner (1999) categorizes four different meanings/forms of sovereignty, such as domestic, interdependence, international, and Westphalian sovereignty. Domestic sovereignty means that the domestic authority, structures and the adequate level of control they have within a state’s territory (Krasner, 2004). Interdependence sovereignty, on the other hand, is a state's ability to control movements across borders. International legal sovereignty is the process of states' mutually recognizing each other as independent states (Krasner, 1999). Finally, Westphalian sovereignty entails "the exclusion of external actors from domestic authority configurations” (Krasner, 1999, p. 9). Krasner argues that intervention to 
other states is considered as the violation of the norm associated with both Westphalian sovereignty and international legal sovereignty. Robert H. Jackson (1990), finds two notions of sovereignty: positive and negative. He defines negative sovereignty as the autonomy from external intrusion (non-intervention). It is a legal condition that states attribute to each other. In contrast, positive sovereignty defines the competences "which enable governments to be their own masters” (Jackson, 1990, p. 29). A sovereign state in positive sense is a state that is capable of providing political demands to the people they represent (Jackson, 1990).

The focus of the present study is domestic or internal sovereignty. By internal sovereignty, I mean a political body that possesses "ultimate, final authority to rule, whose decisions are binding upon all citizens, groups and institutions in society” (Heywood, 2004, p. 92). It is a conception of sovereignty defined in the context of the territorial integrity and inviolability of each political community in modern nation states. Within internal sovereignty, political and legal sovereignty can be distinguished. Political sovereignty "refers to the existence of supreme political power, possessed of the ability to command obedience because it monopolizes coercive force” (Heywood, 2004, p. 91). On the other hand, legal, de jure sovereignty, centers on the belief that ultimate authority lies in the laws of the state-the supreme power is determined based on the legal authority (Heywood, 2004). Some scholars argued that "while it belongs to the field of politics, sovereignty is properly, and can only be, a legal conception” (Middleton, 1969, p. 136); others such as Leibholz claimed that sovereignty is a political concept, not legal (Skinner, 2010).

In the current thesis, this distinction between the legal and political will not be underscored, as both dimensions are intertwined in the topic of the research. The political and legal forms of sovereignty are associated with the transformation of sovereignty from the divine 
to the worldly in the Western tradition and the multiple views on sovereignty in Islamic tradition. In Islamic tradition, the ultimate God's authority is manifested through God's laws embodied in revealed texts (shari'a). Both are so subtly intertwined that the distinction between two authorities is unintelligible. The different historical and political trajectories, and distinctive natures of religious experiences of Western and Islamic traditions have shaped the debates on sovereignty into two separate directions. While in the Western tradition the people's ultimate sovereignty emerged with an acceptance that religion and politics are two separate entities, in Islamist tradition the debate is constricted by the question whether the separation is permissible. However, the separability/inseparability of politics from religion involves historically significant debates that inform the contemporary contestations on sovereignty in modern Islamist political thought. In the next section I will offer an account of historical transformations of sovereignty from God to the king, and then from king to people in the Western political thought. I will also elucidate persistent but diverse debates on possibility and impossibility of separating politics from religion in Islamist political thought.

\section{Sovereignty in Historical Context in Christian and Islamic Traditions}

The theoretical underpinnings of sovereignty in Western and Islamist tradition differ to

each other because of their distinctive historical experiences. The thought of sovereignty in both traditions has been informed with the different political status of Christianity and Islam. In Christianity, religion became separated from politics that informed the transformation of sovereignty from God to the King, and then, the King to people. In the early years of Christianity, the ultimate sovereignty bestowed to God; worldly rulers were not entitled to hold supreme and unconditional power over people. God's supreme sovereignty in the late Middle Ages of the European political history, however, eventually got challenged and rulers started to 
claim ruling authority both from the sources of God and people. The Protestant Reformation that led to the ultimate separation of religion from politics in Christianity significantly contributed to the rise of popular sovereignty in the Western political thought. In opposed to the Western tradition, Islamist political history did not experience such a transformation of sovereignty from the God to people. The popular argument in this regard is primarily derived from the theological ground. It contends that Islam as a religion does not allow a space to argue for a political entity separated from religion. It is also argued that Islam as a faith is exceptional to other faiths. There was no central authority in Islam from which it had to be separated in compared to the historical separation of politics from the repressive authority of Church. However, this inseparability thesis of Islam was challenged with an argument that Islam's engagements with politics were diverse and there were practices of governance where religion had been separated from politics in Islamic traditions. These historical debates of both Western and Islamist traditions merit a detailed discussion to understand sovereignty in modern Islamist and Western political thought. In Western thought, politics is considered a temporal subject that is separated from religion whereas in Islamist tradition, there are diverse positions on the issue. ${ }^{12}$ It is because from the beginning of Islamist polity during the time of Prophet Mohammad (PBUH), the political status of Islam and Christianity was different. The early Christian church was a politically insignificant body that eschewed any worldly political affiliation while the Muslim community was political from the beginning (Brown, 2000). Whereas the Prophet Mohammad "presided over both a new religious community and a rapidly expanding new polity”, Jesus was a dissident against a reigning political order, the Roman Empire. (Brown, 2000, p. 46) Furthermore, it is also argued that governance in Islam had been directed in accordance with the codified shari'a, based on the interpretations of the Quran and Hadith (the practices of Mohammad) while there had not been 
such religion based codified laws in Christianity. From Mohammad’s founding of Medina state (622-632) to the early caliphate of his four righteously guided companions ${ }^{13}$ (632-661), then the Umayyad caliphate, followed by the Abbasid caliphate, and later the dynasties and empires ${ }^{14}$, at least for Sunnis, shari'a was the basis of legitimacy for the political order (Hamid, 2016).

In Christian tradition, the fall of the Roman empire and the rise of the centralizedChristian church contributed to the emergence of a religiously dominated political order in the West. Christianity’s marriage with Roman empire replaced the ethical base of politics to Christian ethics. Prior to that, political ethics was dominated by Greek ethical and moral thinking that was entirely this worldly, unrelated to the world of God (Copson 2017). In Roman Empire, the Christian ethics subsequently permeated into other features of the empire; church became an integral part of governance. What is good and bad started to be defined in Christian moral and ethical standard where divinity played a vital role. Augustine argues that sovereignty is destined to the God only. His famous book The City of God unveils this phenomenon by investigating the features of two cities: the city of God, and the earthly city. According to Augustine, the former city is based on spiritual grace, binding the ruler and the ruled to a "common good” while the latter city is fashioned by a love of self and is characterized by absolute power or sovereignty (Heywood, 2004). Augustine is more concerned with/by the moral concept of sovereignty that is not attached to the notion of territory and declared that God is sovereign having absolute authority over all of His creation (Elshtain, 2008). He places the moral principles of Christianity, God's principles, over the political society (Elshtain, 2008). However, Augustine sometimes speaks as though the city of God is the church (Weithman, 2006).

According to Elshtain, Thomas Aquinas and his followers, the Thomists, somewhat like Augustine’s, argue that earthly rulers could not claim a supreme and unconditional power over 
people. However, "the magistracy was bound by an objective legal order that transcended the positive law of particular entities of the rule” (Elshtain, 2008, p. 16). This order, of course, was not beyond God's creation, but rather was a manifestation of His goodness, reason, and love, claimed Aquinas. Hinsley formulates Aquinas’s argument as follows: "within the community ruler and ruled had each renounced their absolute power to Him, as within Christendom the emergency power of Pope and Emperor was His power” (Hinsley, 1986, p. 98). Combining Aristotelianism with the Christian cosmology, Thomists, sought to build a bridge between "Pope and Emperor, between the universal society and the developing regional communities, and within these communities between the rulers and the ruled” (Hinsley, 1986, p. 98). It was an attempt, Hinsley states, to demonstrate that a system existed that derived power both from the people and God. This synthesizing approach established the tradition of dismantling a single divine power's claim of absolute sovereignty over all other entities.

By the time Aquinas wrote, the king had become the embodiment of both the temporal and spiritual power. The absolute sovereignty of God was shared with the sovereignty of the king. This is well articulated in Kantorowicz's seminal book the King's Two Bodies. His central argument is that the king has two bodies - body natural, and body politic. The body natural is a physical body, mortal and subject to all infirmities. On the other hand, the body politic is a body that consists of government and policy that is established for the people's direction and public welfare. The latter is eternal, devoid of any infirmities, old age or damage. The body natural is the head while the body politic is the body, a combination of his self and his subjects. Therefore, although the body natural dies, the body politic perpetually sustains and transforms from one body natural to the other. Kantorowicz argues that the king's two bodies "form a single indivisible unit, each being fully included in the other” (Kantorowicz, 1957, p. 9). However, he 
places the body politic over the natural body. He symbolically writes that the body politic is similar to the church that represents the divine entity in the earth while the body natural, the king is bestowed with the divine authority and the body politic represents that spiritual authority. This representation of spiritual authority justifies the king's divine right to rule his subjects perpetually. Nevertheless, the argument for the simultaneous existence of the temporal and spiritual power in Western politics did not last long. The spiritual justification of rulers gradually began to be contested that subsequently led the decline of the divine validation for the king's sovereign power, paving the way for the separation of religion and politics ${ }^{15}$ and opening the door for popular sovereignty. The historical juncture that distinctly contributed to the disintegration of politics from Christianity and subsequently played a crucial role to the emergence of popular sovereignty, was the Protestant Reformation.

The Protestant Reformation broke down the medieval synthesis between what the church understood and taught as revelation and natural law as understood by reason. Because Protestants did not accept the authority of the church over the content of revelation, they shifted both the authority and content of revelation to the Bible (Johnson, 2014). Martin Luther preached a sermon for two kinds of righteousness: the righteousness in the eyes of God and the righteousness in the eyes of the World (Copson, 2017). The former was associated with the faith, exhibited not only by the Christian but by adherents of other beliefs while the latter, although was not mandatory for the divine salvation, it was essential for the civil cause. The civil righteousness is to conform with the state laws and maintain its obligations such as paying taxes, following traffic rules, helping fellow citizens (Copson, 2017). It stands with a credibility that this civil righteousness carries a universal humane value. These ideals not only exhibited by Christians but by the devotees of other faiths. Copson (2017, p. 13) further argues that Luther's 
idea of two righteousnesses laid the foundations for a political belief that "princes should not interfere in or coerce faith and that government's right to prescribe behaviors should not trespass on the territory of religion but limited to the civil realm.” The separation of religion and politics in the Western political thought and the rise of popular sovereignty were theorized by the philosophers such as Jean Bodin, Thomas Hobbes, Jean-Jacques Rousseau, John Locke, among others. I will discuss their theoretical underpinnings in the next section of this chapter. While Protestant Reformation paved the way of Christianity's separation from politics such clear-cut separation did not happen in Islam because of the absence of a central clerical authority like a church of Christianity that used to dominate politics. In Islam, two school of thoughts could be identified. One school argues that religion can never be separated from politics in Islam while the other school argues the opposite.

In the first school, the dominant belief is that politics is inseparable from Islam. The frequently cited argument tells us that a fusion of spiritual and temporal authority governed the first "Islamic state" established in Medina during the latter half of the Prophet Mohammed's life (Philpott, 2007). Subsequently, the predominant Sunni community of Islam favored a Caliph, a common spiritual and temporal head of the Islamic people, the ummah. Moreover, it is also argued that the very political orientation of Mohammad and Jesus Christ was distinctive that contributed to the different political contours of two religions. While Mohammad was a part of power in Medina, Jesus was subversive to the Roman Empire (Hamid, 2016). The first state was fashioned in Islamic tradition in Medina where Islamic norms and ethos informed all apparatuses of the state whereas such formation of state did not happen under Jesus. This argument led Hamid to maintain, predilecting upon a comparative historical analysis of the origin and activism of early Islam and Christianity, that, unlike Christianity, politics is intertwined with Islam from 
the beginning. Islam's inseparability from politics, thus, could not be measured in the context of the Christianity's separability thesis that went thought very different experience from the foundation. Hamid calls it the "Islamic exceptionalism." Apart from this political difference from Christianity, it is argued that the nature of Islam as a religion and its everyday practices are structured in a way that its adherents inherently become political. Cook (2014) after a comparative discussion of Islam, Christianity, and Hinduism, concludes that Islam offers richer resources to be engaged with politics. He explains that when a Muslim reads scripture, he finds the Quran and the prophetic model as a preponderance of commands to observe various aspects of Islamic law. These gradually become integral part of Muslim's daily life. Therefore, a practicing Muslim inevitably enters politics. Likewise, Lewis (1988) argues that unlike Christianity that moved towards the separation of religion from politics, Islam moved to the opposite direction. Apart from the scriptures and the political practices of Mohammad and four rightly guided caliphs, the interface of religion and politics, in the process of the early Islam's rapid expansion and governance of empires, established a system of governance where religion was an integral part. During this time, "political authority was not human evil, but it was a divine good" (Lewis, 1988, p. 25). Brown (2000) contests this position. He argues that rulers in Islamic tradition never ruled from the theological ground. It is the ulama who used to define the religious limits to the Royal authority. The ulama, the clergy class, unlike Christianity only did have the power to restraint rulers from being rapacious imposing religious moral resistance to their way. However, this position of inseparability has been challenged from various grounds. Ira Lapidus (1996) tells us that Islamic societies vary in their orientation and interpretation of religion's engagement with politics. There is no single model but multiple ways of engagements of Islam with politics. These models are ambiguous concerning the distribution of authority, functions, 
and relations among institutions. An-Na'im (2008, pp. 53-54) claims that historically the states under which Muslims lived were never religious, regardless of the occasional claims to the contrary. With the dominant inseparability model, another model also always existed that argued for the complete separation between religious and political authorities. An-Na'im argues that in Islamic history two dominant models that explain the relationship between the state and religious institutions can be discerned. The first model claims complete convergence. Based on the prototype of the Prophet in Medina, it assumes that political and religious leaders must be intertwined. In this model, the separation of religion and politics is thought to be impossible. The second model, as An-Na'im writes, is the complete separation between religious and political authorities.

This model although practically realized in the history of Islamic governance, was never theoretically acknowledged. One of the reasons it was not recognized is that the rulers invariably used the inseparability thesis as a tool to legitimize their often otherwise illegitimate rule (AnNa'im, 2008). Practically, rulers as worldly entity governed all political affairs, but when they got challenged in any ground, they used to employ religious justifications for that. An-Na'im further argues that the separation of Islam and politics occurred after the death of the Prophet Mohammad as neither any human being nor even four guided Caliphs were entitled to enjoy both religious and political authority. He substantiates his argument with historical evidence of how people challenged the Caliphs’ authority. He writes:

I am proposing the differentiation between religious and political authorities that can be traced back to the time when Abu Bakr became the first caliph of the Medina state. The fact that this view is not prevalent among Muslims today does not by itself mean that it is wrong. On the contrary, the deep crisis Muslims everywhere are experiencing regarding the relationship of Islam to the state and politics indicates the need for a fresh reading of history for guidance about the future of Shari'a in Islamic societies (An-Na'im, 2008, p. $55)$. 
This separation thesis of religion and politics in Islam is also highlighted in the seminal work of Crone and Hinds' God's Caliph. They maintain that after the death of Mohammad, who was the God's representative of both religious and political matters, the political authority passed to the new head of the state, but the religious authority ceased to be transformed (Crone \& Hinds, 1986). On the other hand, the religious authority of interpreting the sayings of Mohammad passed to the people who remembered those later compiled as hadith literature. These men, the companions of Mohammad, transmitted their recollection of his words and deeds to the subsequent generations. This scholarly group later emerged as the ulama class. But, ulama did not have, neither did they claim, any divine religious authority. But Crone and Hinds contend that the first four Caliphs (Abu Bakr, Umar, Uthman, $\mathrm{Ali}^{16}$ ) did not claim themselves the viceregent of God. Instead, they claimed to be the vice-regent of Mohammad. During their regimes, it was not permissible to use the expression Caliph of God. Abu Bakr, the first Caliph said, "I am not Caliph of God, but the Caliph (representative, successor) of the Messenger of God” (Razek, 2013, p. 27). After Ali's death, "the Caliphate passed to men who had converted late and unwillingly (the Umayyads) so that the happy union of religion and politics now finally came to an end" (Crone \& Hinds 1986: 2).

This religion and politics separation were maintained in Islamic Empires and dynasties in subsequent centuries. In the dynasties of early Islam and Empires such as Safavid, Ottoman, and Mughal of Islamic history, religion was never the basis of governance (An-Na'im, 2008; Lapidus, 1996, 1975). Lapidus, (1996, pp. 19-20) argues that religion and politics although were separated in practice, were never clearly articulated in theoretical debates in Islamist political thought. The separation was also not recognized in ordinary Muslim imagination of the state. Moreover, Muslim empires cultivated a religious aura from Islam and practiced political culture 
based on siyas ${ }^{17}$ the exercise of power justified in its own terms, a form of raison d'etre political rationality. They, like the Monarchy in the Western tradition, loved to act as if they were divinely selected person, God's vice-regent on earth assigned to protect the people (Lapidus, 1975). However, there was ambiguity regarding the secular and sacred. People's daily affairs were dominated mostly by the religiously informed laws and cultures whereas political affairs were not driven by strict religious rules. It was evident that the ulama's (Islamic scholars) religious and educational activities were brought under the bureaucracy of the Ottoman Empire. Even though, in Ottoman and Safavid Empires, the state had control over religious leaders, it did not "obliterate the distinction between the court, military and bureaucratic elites on the one hand, and the religious teachers on the other, nor the distinctions of function, ethos and authority between them” (Lapidus, 1996, p. 18). The states concentrated on military power, public order, and taxation while the religious leaders focused on individual learning, pious practices, prayer and ritual, social welfare and the mediation of local disputes. In Mughal Empire, initially, the rulers sought formal legitimacy the Khilafat office of Cairo (After the collapse of the Abbasids in Baghdad the seat of Khilafat shifted to Cairo in 1261) as the temporal authority was exercised by the reigning Mameluke sultans (Jalal, 2000 ). Jalal argues that following the subjugation of the Mamelukes as the Khalifat was voluntarily transferred to the Ottomans, the Mughals without disputing the hereditary right of the Ottomans, dispensed with ceremonial displays of their subordination to the Dar-ul-Khilafat, the seat of Islam. But the Mughal rulers' authority, as it was the case of the Royal Ottoman emperors, remained more temporal than spiritual (Jalal, 2000 ) .

The separability and inseparability debates have significant implication to the theories of sovereignty in modern Islamist political thought. The divine sovereignty theory of Mawdudi and 
Qutb is derived from the arguments of inseparability debates. Their interpretation is that the argument for Islam's separation from politics poses a challenge to the ultimate sovereignty of God in Islam. On the other hand, the contention for the sovereignty of ummah propagated by Ghannouchi is drawn from the separability arguments and practices in the history of Islamic governance. Drawing from the siyasa shariiyya tradition of Islamic governance, Ghannouchi argues that the separation of Islam from politics does not undermine God's ultimate sovereignty. The details of the theoretical implications of these debates will be discussed in the chapter three and four of this thesis. The theoretical understanding on sovereignty in modern Islamist political thought could better be understood by locating them vis-à-vis the liberal Western political scholars' take on the issue. In the following section, I will elucidate the theoretical emergence of popular sovereignty in Western political thought. I will particularly look at the theoretical underpinnings of the decline of religious authority and the rise of secular authority within the trajectories of Christian Reformation, the decline of the church's authority over political affairs, and the emergence of nation-states that led the normative shift of sovereignty from divine to people.

\section{Popular Sovereignty in the Western Political Thought}

After the Reformation, Bodin for the first time unambiguously declared that sovereignty must be absolute, perpetual, and undivided. People must be the original carrier of absolute power. However, he did not reject the medieval reference to divine sovereignty. Bodin argued that the ruler of a state should have complete authority in his own territory and should be accountable only to the divinely inspired natural laws. Bodin asserts that neither the land nor the persons make the city, but it is the union of the people under a sovereign government that makes it (Bodin, 1955). Hobbes, on the other hand, breaks away from the medieval thoughts entirely, 
arguing that people are the sole sovereign. People's sovereignty must not be shared with any other temporal or spiritual entity. He emphasizes the term "people" more vigorously than that of Bodin. For Hobbes, people are not merely the accumulation of individual without agency; they have agents to be acknowledged fully (Hinsley, 1986). According to Hobbes, it is not the fact that people must necessarily depend on God's command for worldly tasks to perform but could accomplish those with an agency derived from the nature. In a similar vein, John Locke advanced the concept of popular sovereignty underscoring people's agency. He contends, it is the people "who decide when a breach of trust has occurred," and it is the people who have the right to resist against the ruler (Locke, 1988, p. 115). Similarly, Rousseau maintained that sovereignty can never be alienated from people (Scott, 2000). While Hobbes and Bodin’s contention is that the sovereign ruler is separate from the mass, Rousseau argues that a ruler remains within the contract made in the community. Rousseau writes, "that man [ruler], even if he had enslaved half the world, still remains nothing but a private individual; his interest, separate from that of the others, still remains nothing but a private interest” (Rousseau, 1997, p. 48).

While discussing popular sovereignty in the major theorists' writings in the Western political thought, a few important aspects pertinent to the topic of the present thesis need to be explored further. First of all, who is sovereign in their concept of popular sovereignty? How do they situate the people's ultimate sovereignty in relation to divine authority? Relatedly, what determines the relationship between the ruler and the ruled? And, from what sources rulers get legitimacy to govern? Finally, how the theorists recognize the individual agency in the popular sovereignty. 
The evolution of popular sovereignty in these theorists' arguments offers diverse answers to these questions. For Bodin and Hobbes who preferred a monarchy, a strong king is the sovereign whereas Locke and Rousseau argue for people to be the ultimate sovereign. Bodin's monarch derived his governing authority both from spiritual and temporal sources while Hobbes' absolute monarch derived its legitimacy from people. Somewhat similarly, Locke’s sovereign derives legitimacy from multiple sources where sovereigns co-exist harmoniously. Hobbes and Rousseau broke from the medieval tradition of spiritual- temporal duality for the sources of the sovereign's legitimacy and argued that a ruler could only be a legitimate power if he gets people’s consent. In contrast, Bodin and Locke’s reference for natural law/right/divine authority for legitimacy rests in ambivalence. It is debated whether they referred to God literally or figuratively. For many scholars, Bodin and Locke used God's reference as a tool to impose a moral binding on the rulership. The Lockean metaphysical existence of God denotes that in the state of nature under God's ambit human beings are free and equal. The rulers also are the equal part of the whole and subject to the laws they formulate.

The basis of the rulers and ruled relations is a social contract in all theorists' arguments. The contract could be interpreted as this worldly, although Locke and Bodin refer to God's presentence in the contract in metaphysical sense. In Bodinian and Hobbesian social contract, the ruler gets the absolute authority to govern where individuals remain passive while in Lockean and Rousseauian contract rulers are accountable to individuals where individuals have right to resist against them anytime. Finally, although all theorists admit individual agency, the dimension and its extent differ. Rousseau's recognition for an individual agency is evident when he argues that individual rights are totally alienated; cannot be represented or delegated. Hobbes also accepts individual agency, but that agency becomes dormant with the delegation of 
individual's authority to the sovereign ruler. In contrast, in Bodin and Locke's arguments on sovereignty, individual agency is not fully acknowledged. To them, a human agency could be asserted as long as it does not violate the divine laws. In the discussions that follow I will illustrate these theoretical intricacies on popular sovereignty of the scholars mentioned. The absolute power of the sovereign as Bodin writes in Six Books of the Common Wealth, is unconditional unless the conditions of appointment are inherent in the laws of God and nature. All "the princes of the earth are subject to the divine and natural laws and cannot contravene them” (Bodin, 1955, p. 29). The absolute authority to formulate positive laws lies on the ruler, which is valid as long as that does not contradict God's laws. The laws of a sovereign prince cannot disregard or modify, even partially, the laws of God and nature. The absolute power only implies freedom concerning positive laws, not over natural laws. Bodin differentiates between a king and a tyrant (Bodin, 1955, pp. 62-69). The former is he who conforms the law of nature, is directed by faith, piety and justice. He devotes to the welfare of his subjects. In contrast, the later, the tyrant ruler consults only his own profit and pleasure contradicting his faith and God's law. Bodin further argues that subjects are permitted to resist their king only if they become tyrant and contradict God's command.

Bodin further argues that "the ruler cannot remit any penalty imposed by the law of God as he, himself is subject to God's laws.” However, it is not necessarily the case that the ruler entirely devoid of the power of mercy. The ruler can show his clemency by exonerating the violations of positive laws. For example, the ruler can forgive the people committing crimes such as carrying arms or selling of foodstuffs to the enemy in time of war, on pain of death for a valid reason. Bodin argues for an absolute monarch. He contends that sovereign majesty possesses the right and absolute power "to impose laws generally on all subjects regardless of their consent" 
(Bodin, 1955, p. 32). The monarch must be above the law, and he must remain separated from his subjects. The rationale for Bodin's argument that the ruler should be above the laws those he formulates is that he always remains bound to maintain the laws of God and nature. For example, he claims that the ruler cannot commit homicide because it breaks the natural law. Besides, the ruler cannot act on his wishes because of his moral commitment to his subjects. Bodin held that the ruler has double obligations. He is, on the one hand, restrained by the principles of natural equity that requires the conventions and his solemn promises to be maintained. On the other hand, the ruler is bound by his own principles and promises because he is "the formal guarantor to all his subjects of the mutual faith they owe one another” (Bodin 1955:34).

Bodin's reference to God, however, is ambiguous. He neither clarifies the difference between God's laws and natural laws nor illustrates the distinction between the natural laws and positive laws. It, therefore, could be interpreted that Bodin referred the God's law/natural law rhetorically as the tool to check prince's misuse of the absolute power. The reference to God in the absence of any concrete idea of natural law is, therefore, a moral binding for rulers. It could be assumed that for Bodin, a ruler without moral imposition on his works, might emerge to be tyrannical. God's authority could be, for him, the better moral source as by the time Bodin was writing, the Christianity's hold over politics was still dominant. The alternative moral sources, viz. the rationality-based secular moral ethos was yet to emerge. Without this moral imposition rulers are free to act wishfully as Bodin argues that any positive law does not bound the sovereign. The objective of limiting absolute power was an effort to prevent civil war in Europe and establish peace in Bodin’s time (Holmes, 1988). For Holmes, Bodin’s ambiguous reference to God and limiting the sovereign power is a necessary mystery, what Keohane defines as a “necessary condition for the exercise of power” (Keohane, 1980, p. 47). 
In opposition, some scholars determine Bodin’s reference to God similar to an indication to an extra-legal authority. It is, Skinner argues, partly associated with the thought of the king's divine right to rule. The principle is that rulers achieve their authority directly from the God, not from the people. In other words, "Kings are the Lord's anointed, the vicegerents of God on earth, and consequently enjoy supreme and unquestionable power over the body of the commonwealth or state" (Skinner, 2010, p. 29). In this sense, “God imposed the chain of being upon nature and maintained each and every link of it at every moment” (Engster, 2001, p. 79). Engster further argues that Bodin's contention on sovereignty claims that God had delegated to the sovereign authority the responsibility of imposing a divine and natural order upon human affairs. For him, Bodin's sovereign retains both absolute temporal authority and spiritual mandate to rule. The divine and natural law identified the sovereign authority as the sole pivot of legitimate law and order (Engster, 2001). This argument for an extra-legal authority, however, is not the dominant trend amongst the interpretations of Bodin's sovereignty. Holmes argues that Bodin is far from being arguing for a purely extra- legal authority and pious exponent of natural laws (Holmes, 1988). The God's reference in his thought is treated as secondary or marginal. J. W. Allen held that Bodin believed in the divine right of the king only because everyone of his time believed in it. Sovereignty is man's creation; any special act of God does not create it.

Unlike Bodin and other precursors, Hobbes starts Leviathan, not with a given social organism such as a family with its established pattern of authority that is dictated by nature and by God (Lloyd, 1991). He begins, rather, from the principles of integration between the individual human beings and the material world where they live. For him, it was important to examine how things in this world engage to each other, instead of God's role on them. He departs from the old temporal and spiritual duality of authority and declares that the religious 
leaders such as bishops and church, do not hold "any authority to command other men" (Hobbes, 1952, p. 387). He claims, while God's will on the earth is unknowable, human being understands God's expectations from them based on two sources: reason and scripture. He argues that God created human being with reason and ensured that there is nothing contrary to it, and there is a perfect balance between the reason and revelation. For him: things those appear to people as contrary to reason is the fault "either in their unskillful interpretation or erroneous ratiocination" (Hobbes, 1952, p. 185). He further maintains that God created human beings with reason to rule over their conduct. He, with his vision of voluntaristic God, reached to an unorthodox conclusion that "subordinates divine law to natural law, faith to reason, and religion to the state" (Engster, 2001, p. 185). The other source of knowing God, scripture, is also subordinated to reason in Hobbesian understanding. He contends, since divine law of scripture was uncertain and open to diverse interpretations, reason should be the authoritative guide of public worship and welfare (Engster, 2001).

Since reason leads over other concerns of human survival to Hobbesian state of nature, Hobbes characterizes the state as a rational entity and a mortal God. State's mechanism is driven by worldly concerns and contestations. God's reference that occasionally appears in his writings is more from the moral reference as Hobbes projects state as a means to institute a political order similar to God's universal moral order. The state, for Hobbes, stands in for God in defining the principles of natural law and maintaining the state of peace (Engster, 2001). According to Engster Hobbes ultimately proposes to restore human beings to the static and universal political order related to the medieval theories of the state. Engster comments: "his Leviathan resolved the most severe existential anxieties of human beings by establishing a universal political order standing apart from the irrational stream of temporal affairs” (Engster, 2001, p. 183). In the 
process of state formation, Hobbes rejects the medieval vision of a self-enforcing natural law. His assumption, rather, is that human society is naturally dominated by anxiety, ignorance, passion, and corruption. They are "all against all, in a state of war where everyone struggles for self-preservation” (Hobbes, 1952). It is fear that leads them to actualize natural law, for that human being needed to institute a state authority to rule over them. It is asserted that state would impose a moral and natural order upon the human being. For state authority to establish, individual consent was necessary. The social contract, for Hobbes, was that individual would lay down their natural rights to all things and determine a ruler to establish an artificial order for their self- preservation. All that required for a legitimate political regime was "the tacit consent of the subjects, and this could be assumed by just as long as the state provided them with peace and security” (Hobbes, 1952, pp. 127-128). In Hobbesian contract, the rulers are not bound by the laws they make. Hobbes explains that there is no contract between the sovereign legislator and the subjects because the sovereign is not subject to the laws he formulates (Hinsley, 1986, p. 143). The governing rationality he mentions is the rationality of the absolute ruler that he supports, not the rationality of his subjects. The sovereignty of the ruler in Hobbesian state is “unlimited, illimitable, irresponsible, and omnipotent” (Hinsley, 1986, p. 143).

However, for Hobbes, individual has rational choice but that is to surrender their will to the sovereign for security. The individual rationally decides to submit their will voluntarily. However, upon submission the will, the relationship between the sovereign and people does not become passive in Hobbesian sovereignty. He argues that people instead remain active and participatory. After submitting a consent to the sovereign, the people continue to be the authors whatever action is taken by the sovereign (Hobbes, 1952, pp. 124-126). Hobbes claims that with the submission of sovereignty to the rulers, people must be willing to regard themselves as 
owners of whatever is subsequently said or done by them. People must accept responsibility for their actions as if those had been of people's own (Skinner, 2002).

While Hobbes argues for ruler's absolute sovereignty, Locke did the opposite breaking away from the absolutist arguments of his predecessors. Unlike Hobbes who shifted sovereignty wholly to the state, Locke strived to retain that for the people. He thought of rulership as merely the carrier of executive power on trust, basing "the creation of the body politic on the social contract rather than on the covenant of submission” (Hinsley, 1986, p. 147). While in the Hobbesian state of nature, the extreme fear drives individuals to submit their complete will to the sovereign, in Lockean state of nature, it is not the extreme fear that drives individuals to do so. In Lockean state of nature, individuals would be bound morally by the natural law to live peacefully. The basis to form a secure society, for Locke and get away the state of war, is the legislature. He comments that for ending all differences that may arise among them and based on their legislative "the members of a commonwealth are united and combined together into one coherent body" (Locke, 1988, p. 407). The individuals collectively give their consent to delegate a group to formulate legislature for the welfare of them and authorize them to rule.

After delegating the power to the ruling authority, however, the people remain the judge of their rulership if they perform according to the power reposed to them. People who deputed the authority to rule, still have a power to discard them. Unlike Hobbes, Locke argues that after making laws, the rulers themselves remain within the jurisdiction of laws, not above those. The individual with the power of legislating, "when they have done, they are themselves subject to the laws they have made” (Locke, 1988, p. 264). Locke envisions a relationship between the rulers and people placing people in the center where people act collectively to legitimize the 
political authority. The only legitimate basis of government for Locke was popular consent. The basis of all "political authority is consent, not inheritance" (Locke, 1988, p. 329).

In Lockean sovereignty "no earthly being possesses exclusive dominion; thus, everyone possesses reciprocal power and jurisdiction” (Scott, 2000, p. 550). Therefore, according to Scott, Locke's most significant contribution to the debate of popular sovereignty is to argue that "individual by nature possesses the power of judging and executing the laws of nature that in traditional sovereignty theories were 'ascribed to the sovereign alone’” (Scott, 2000, p. 551). According to Locke, individual rights should be sacred; its violation is contrary to natural law. The individual has "by nature a power, not only to preserve his property, that is, his life, liberty, and estate, against the injuries and attempts of other men; but to judge of and punish the breaches of that law in others” (Locke, 1988, pp. 323-324). In a Lockean state of nature, a human being is free and equal. It is in the sense that a human being is God's property. Under an omnipresent God's ambit, all are equal; there is no hierarchy of relations among them. Because of being God's property, human being cannot own one another. Locke argues: “all men by nature are equal” due to God's decision (Locke, 1988, p. 122). He argues: “Men being, as has been said, by nature, all free, equal, and independent, no one can be put out of this Estate, and subjected to the Political Power of another, without his own consent” (Locke, 1988, p. 330). A naturally free individual cannot reasonably relinquish their rights to a sovereign in the traditional sense, a powerful ruler in Hobbesian sovereignty. It is because Locke asserts, individuals are equally born without "subordination or subjugation" unless there is a manifest declaration by "the Lord and master of them all” that one person has "an undoubted right to dominion and sovereignty" (Locke, 1988, p. 269). 
Nevertheless, Locke maintains that men are neither irrational nor without their agency although they function within God's right (natural law). God's decision to make men equal to each other under natural law's protection also offers them the individual agency. Men are miniature gods on Locke's account in that, unless they do not violate natural law, they stand in the similar relation to the objects they create as God stands to them (Shapiro, 2003). Men own their creations as God owns them. Locke argues that God actually treats a human being like his peers and gives them agency to act. Therefore, on Locke’s account, political institutions established by human being remain their property through a social contract. They are inherently rational in similar capacities where rank does not give privilege access to reason. Locke perceives that adults are capable of reasoning equally and the moral equality of human was evident in revealed texts (Shapiro, 2003). God, Locke insists,

Has not been so sparing to men to make them barely two-legged creatures, leaving it to Aristotle to make them rational...He has given them a mind that can reason, without being instructed in methods of syllogizing: the understanding is not taught to reason by these rules; it has native faculty to perceive the coherence or incoherence of its ideas and can range them right, without any such perplexing repetitions (Shapiro, 2003, p. 318).

One interpretation is that God owns the ultimate sovereignty in Lockean thought. Locke contends, "For where there is no judicature on earth, to decide controversies amongst men, God in heaven is the judge. He alone, it is true, is the judge of the right” (Locke, 1988, p. 427). The assumption is that if individual faces injustice under a tyrant, he must summon to God seeking the ultimate justice. In this interpretation, it is argued that in Locke’s thought there is a clear fusion between the faith and politics, the legacy that he carries from Aquinas. It appears to be anti-thesis to the separation theory in the Western political thought that posits that religion and politics got separated after the Protestant Reformation. The King in this interpretation is the deputy of God, governs in favor of God on earth (Gencer, 2010, p. 329). It is clarified in Dunn's 
statement when he notes that all lawful "authority everywhere and always exercised by one human being over another is an authority conferred upon him ultimately by God” (Dunn, 1995, p. 27).

The other interpretation of Lockean sovereignty is that Locke, on the one hand, articulates the individual agency to lawmaking and the legitimate right to resist against the rulers, and on the other, he acknowledges God as the ultimate authority. It stimulates, therefore, a perennial debate. The debate is how to maintain individual personal property for selfpreservation on the one hand and, simultaneously to claim that God owns that individual property, on the other. Many find this workmanship argument is contradictory to the individual’s inalienable rights (Glenn, 1984; Simmons, 1993). Some scholars, however, comment that Locke's sovereignty was a coexistence of his divine workmanship and his consideration for the natural right to self-preservation (Grant, 1987). Scott advances this interpretation arguing that in the Lockean state, several claimants of ultimate authority can “coexist without a common authority in theoretical harmony" (Scott, 2000, p. 552). These claimants include God's supreme authority, the free individual in the state of nature, society or the people, the legislative and the executive. He argues that none of them is the ultimate sovereign in the traditional sense in Locke's thought. In Scott's language, in Lockean moral and legal conditions where "individual can understand their relations to one another provides the means for the theoretical coexistence of several supreme powers and the simultaneous affirmation of ultimate sovereignty of the individual, God, society and state” (Scott, 2000, p. 552). Above all, Locke's sovereignty in the context of modern secularized popular sovereignty could be seen as the middle ground between the earlier divine sovereignty's absolute God's authority and modern secularized sovereignty's absolute authority of people. He argues for 
people’s agency to resist against tyranny and paradoxically, keeps God's authority as a reference point.

Rousseau, on the other hand, does not acknowledge the existence of God's sovereignty, and argues that people are the ultimate sovereign. Whereas in the Hobbesian version of social contract, sovereignty is transformed from the people to the state and its ruler and in Lockean social contract multiple claimants of "supreme sovereign coexists" (Scott, 2000), the Rousseauian social contract claims, "sovereignty is not only originating from the people; it ought to stay there” (Rousseau, 1997, p. 57). He comes out of the limitations of traditional social contract theories where natural law, or natural rights or God's existence on earth put limits towards the people's absolute authority. He argues that the rights in the state of nature are not rights, but powers (Croker, 1968). For him, a right which is moral and legal entity those come into existence with civil society, with an ambiance of interdependence among people. Rousseau further maintains that God's supremacy does not require much work to harmonize a chaotic state of nature that could only be harmonized with collective participation in forming a social order. It is individual in communities who are to decide collectively on the matters of governance to live in peace and harmony. Rousseau elucidates that as God harmonizes cosmic affairs and maintain a cosmic order, in a state, people harmonize the "disorder of individual wills" (Croker, 1968, p. 46).

For Rousseau, sovereignty cannot belong to anyone, in particular, it can only belong to everyone. It means that the supreme sovereign is the people as a whole. Unlike his predecessors, he clearly states that individual agency is the decisive factor of sovereignty. The individual has absolute agency to elect rulers and resist against them. Rousseau argues that for a common good in communities, individual submits their will under the supreme the general will, the ultimate 
sovereign. In the process, individual will remains indivisible part of the whole (Rousseau, 1997, p. 50). Once the wills are submitted to the prince under a general will, he does not enjoy absolute sovereignty as Hobbes’ ruler does, but his authority has to be taken from the people and remain accountable to them. Rousseau argues: “the trustees of the executive power are not the people’s masters but its officers, it can establish or remove them whenever it pleases” (Rousseau, 1997, p. 118). For Rousseau,

The power to dismiss government, which was merely the non-sovereign executor of the legislative commands of the sovereign community, was permanently exercised by the community, which automatically suspended the government's commission whenever it assembled, because the unlimited sovereignty of the people could be bound by no law or constitution and could not be transferred even as to its exercise (Hinsley, 1986, p. 154).

In developing the process of government, Rousseau celebrates the notion of an active, involved citizenry. Unlike Hobbes, Rousseau maintains that all citizens must have the equal voice in the collective decisions. The laws are universal in character where everyone irrespective to the position in the society, including who is assigned for lawmaking, are subject to the laws. For a fair society to exist, Rousseau argues that it demands that individual forfeit everything to the community under the direction of the common good. Unlike Hobbesian sovereignty where people are collectively represented by the sovereign, Rousseauian sovereignty cannot be represented. Rousseau’s famous passage says:

"Sovereignty cannot be represented, for the same reason that it cannot be alienated...the people's deputies are not and could not be its representatives; they are merely its agents, and they cannot decide anything finally. Any law which the people has not ratified in person is void; it is not law at all. The English people believes itself to be free; it is gravely mistaken; it is free only during the election of Members of Parliament; as soon as the Members are elected, the people is enslaved; it is nothing” (Rousseau, 1997, p. 141). 
The state in such political community is equaled to the body politic of the people. It was formed through the social contract between the people associated with the political process where the government's role reduced to only a commission (Hinsley, 1986).

By the social contract, Rousseau means a contract where individual rights are totally disaffected. He writes: "Each of us puts in common his person and all his powers under the supreme direction of the general will; and in our corporate capacity we receive each member as an indivisible part of the whole” (Rousseau, 1997, p. 50). The features of Rousseauian sovereignty could be summarized the following way: all members of the association are to have a voice in the general assembly; no individual can be lawfully excluded. Sovereignty is inalienable. It emanates from the individual and stays with them. The assembly cannot transfer power unless it gets authorizations from the individual. Sovereignty for Rousseau is also indivisible. He argues that it seems to all that sovereignty is divided in various means and expressions of power such as executive, legislative, judiciary and other authorities. It is not true. Rousseau rather contends that all these seemingly divided forms of sovereignty is subordinated to the collective general will is established with the participation of the individuals (Rousseau, 1997, pp. 58-59).

Finally, Rousseau although denied any religious-spiritual authority in political affairs, he did not reject the role of religion in the community in the form of civil religion. Discarding different political uses of religion, he argues that religion as a part of faith and its moral ethos have significant contribution to the formation of a harmonious community. He contends that in this "genuine and sublime” form of religion where everyone is regarded as the children of the same God, and individuals treat each other as brothers where all are bounded in a societal relationship. He, however, declares that this religious practices and ethos do not have any relationship with the body politics of the state. This leaves the laws and other apparatuses of the 
state with only the power that is derived from the individual wills without adding any other powers to that. Thus, individual/people remain the ultimate sovereign, the sovereignty of those is inalienable and indivisible (Rousseau, 1997, pp. 147-148).

\section{Conclusion}

In this chapter, I have summarized a brief historical trajectory of Western political thought from the pre-Greek and Roman moral politics to the rise of Christianity dominated politics to finally the deterioration of the papal dominance from politics. The decline of religious authority and the Protestant Reformation, among other events, led the separation of Christianity from politics in the Western tradition. In that backdrop, with the writings of Bodin, Hobbes, Locke, Rousseau, among other theorists, the absolute God's authority and a medieval spiritualtemporal duality of sovereignty in the Western political thought gradually transformed into the people's ultimate sovereignty.

In the Islamic tradition, on the other hand, I have shown that normatively, the debate has been limited whether politics could be separated from Islam. Although practically, several historical accounts tell that the political affairs in different Islamic dynasties and Empires have been managed in an entirely temporal means. This separation was not normatively articulated because rulers historically exploited the inseparability thesis to legitimize the otherwise “illegitimate" rule. I also argued that, unlike the Western tradition, in Islamist political thought sovereignty was never became the central point of discussion until the early 20th century. It is, therefore, evident that Islamist sovereignty was never theorized and consequently, something like popular sovereignty within Islam is entirely missing.

Nonetheless, based on the discussions and debates of popular sovereignty stated above in the Western political thought, in the following chapters, I will discuss the arguments on 
sovereignty in Islamist political thought. I will look at how Islamist political thinkers such as Mawdudi, Qutb, and Ghannouchi address issues such as the location of sovereignty, the sources of sovereign legitimacy, factors determining relations between the ruler and the ruled, and the extent of personal agency asserted in their scholarship. 


\section{CHAPTER III: THE SOVEREIGNTY OF GOD: MAWDUDI AND QUTB'S THEORY OF DIVINE SOVEREIGNTY}

\section{Introduction}

This chapter examines the theory of divine sovereignty in Islamist political thought explicated in Abul A'la Mawdudi and Syed Qutb’s writings. It consists of three sections. The first section makes an account of the prevalent meanings and contestations concerning the concept of vice-regency in Islam. The section argues that this understanding of vice-regency contributes to the theorization of sovereignty in the modern Islamist political thought. The second section discusses the theoretical underpinnings of divine sovereignty in Islam. It argues that both Mawdudi and Qutb’s theory of sovereignty centers on the Quranic concept tawhid, the oneness of God. For them, God is the ultimate sovereign; no one can claim to share God's authority. From this premise, they argue that religion and politics are inseparable. They maintain that not only the religious authority, but the political authority belongs to God alone. While popular sovereignty emerges from the separation of religion from politics, divine sovereignty in Islam is derived from the unity of faith and politics.

Both scholars perceive shari'a as a codified law that the state is to implement in an Islamic state. As the vice-regent of God, rulers or people are only entitled to implement shari'a; they are not entitled to make new laws. However, Mawdudi and Qutb contend that individuals have a limited agency to formulate laws in God's favor on the subjects where shari'a does not contain any precise dictates. In this regard, they discard the authority of ulama on the interpretations of scriptures stressing on the individual authority of interpreting them. They do not support the reinterpretations of shari'a as they believe that the message of revealed laws is 
universal across time and place. Mawdudi and Qutb reject the worldly social contracts stipulated in the Western political thought, and instead emphasize a contract between God and individual. The Islamic community for them is formed based on the relation of brotherhood that is informed with and inspired by the faith-inspired ethos and morality. The divine sovereignty underscored in Qutb’s theory of divine sovereignty is not only contrary to the post-enlightenment rational thought but could be argued as a reaction to Western modernity.

The final section summarizes the arguments made throughout the chapter. Let me start with the diverse debates regarding the vice-regency in Islam.

\section{Perspectives on Vice-Regency in Islam}

Khilafate Allah or the vice-regency of God has been intensely debated in the history of Islamic governance. Modern Islamists also rely on diverse interpretations of the concept to substantiate their positions of governance in general, and sovereignty in particular. Pertinent to present thesis, I show that Mawdudi and Qutb, based on the interpretation that man is the viceregent of God, attempts to substantiates their position of divine sovereignty. I, however, argue that their claim remains ambiguous. In the next chapter, I also show that Ghannouchi's clear interpretation that people are the God's vice-regent informs his position of the sovereignty of

ummah. Before moving to the modern Islamists interpretations of vice-regency, an account of historical debates on the concept is necessary.

The question of the Caliphate, an issue of intense debate in the early and medieval Islam, re-emerged in the 1920s, and since then dominates the modern Islamist political thought in different manners, and in various contexts. Caliphate was established immediately after the demise of Prophet Mohammad to manage the community of the faithful he had founded and to sustain the momentum created by the then-new religious message. Initially the title Caliph 
generally used to mean "deputy" or "successor" and was given to the immediate- prominent companions of the prophet who had been granted by circles of influential members to lead the community. In Sunni Islam, the first four caliphs are accepted as the legitimate ones. However, the Caliphate was taken over by a succession of ruling families from the beginning of Umayyads to the end of Ottomans. ${ }^{18}$ This succession of rulers from the Umayyads to Ottomans engendered diverse debates. Some scholars determined it as coup d'etat, while others regarded this succession of Caliphate as un-Islamic. It is because the scholars argue that the succession violated the principles of the Islamic community’s integrity and freedom (Razek, 2013). Ibn Khaldun argues that during the first four Caliphs of Islam, regime of Caliphate was uncontested; but as Caliphate assumed royal authority, characteristics of it became confusing. He commented that Caliphate's acceptance of royal authority in different dynasties and empires of Islam separated it from the spirit of collective solidarity of the original Caliphate (Razek 2013).

The term "Khalifa" historically remained an important issue in Islamic theology, history, and politics. It has been studied by several modern scholars, including Goldziher (2006), Arnold (1924) Arnold (1924), Razek (2013), Watt (1971), Hinds \& Crone (1986), Al-Qāḍī (1988), Idris (1990), Alajmi (2011). The term appeared in the Quran in different forms and contexts which allow scholars to offer different interpretations and attach diverse meanings. Al-Qāḍī (1988, pp. 398-408) categorizes the extant meanings into five stands. The first meaning is "to succeed, to follow, to come after another.” The second meaning is to replace, to substitute, to take the place of another, or to deputize for. The third meaning is associated with the first two that is "someone would take the place of another when the latter is completely nonexistent.” The next understanding of the term, for Qadi, is to inhabit or cultivate. And the final meaning of the term 
is related to political authority, in that some early exegetes believed Khalifa to mean the just governance of society.

Despite their ostensible differences, all these meanings are associated with each other. For the students of political thought, the meaning connected to political/spiritual authority gets prioritized. This is expressed as Khilafate Allah. The literal meaning is the vice-regency of God, a crucial but contested concept in Islamist political thought. The popular understanding is that the human being is the vice-regent of God on earth. The argument is that man does not possess the absolute authority to rule but rather works as the deputy of God. Idris (1990) offers an account of key historical debates on the issue which in various ways overlaps with Al-Qadi's expositions. The early interpretation of it is found in the writings of the $9^{\text {th }}$-century Islamic scholar Al- Tabari. Idris, based on the Quranic verse, “And when God said to the Angels, I shall appoint a Khalifa on earth” (Quran, 2:30), argues that by Khalifa God denotes Adam and "anyone else who his place in obeying God, and who observes justice in judging among his creatures” (Idris, 1990, p. 101). He draws this conclusion from the discussions of Al-Tabari (838-923), and other early scholars of Islam, namely Al- Razi (854-925), Al- Qurtubi (12141273). Idris and his intellectual predecessors’ interpretations of vice-regency can be divided into two categories. In the first meaning, Khalifa is "one who succeeds another.” In this sense, it is not clarified who are the successors of Adam, the rulers or the "entire human genesis” followed him.

The other interpretation is that the decedent of Adam is meant to be a ruler who leads the state. In this sense, the Caliph could be Adam or the rulers of his subsequent generations who are entitled to implement God’s laws. Idris paraphrases the message of Quran based on the early interpretations of vice-regency in the following ways: "I am about to create new beings on the 
earth who shall succeed earlier inhabitants of it, and whose every generation shall succeed the others in inhabiting it, and among whom there shall be rulers who shall judge among the others in accordance with My commands” (Idris, 1990, p. 103). The first four Caliphs of Islam in this sense are the Khalifate Allah, but they held both religious and political authority. The subsequent Caliphs, beginning with the Umayyad dynasty could exercise only the political authority, by no longer able to exercise religious authority enjoyed by their predecessors (Crone \& Hinds 1986). Because, Crone and Hinds maintain, the Umayyad caliphs' title of Khilafate Allah was not driven by religious motivation, but rather it was a tool of legitimacy. In the face of losing their power against the competiting dynasties Umayyads evoked the religious authority. During the regime of Umayyad dynasty, the ulama’s religious authority started to be recognized, and eventually, that came in contestation with the Caliph's claim for having both the religious and political authority. Crone and Hinds assume that Umayyad Caliphs claimed to have a direct viceregency of God by Khalifate Allah. They did not regard themselves as the descendant of Muhammad, rather claimed to be directly the deputies of God. This position, however, is rejected in Ruben's scholarship. Crone and Hinds and Rubenis arguments are based on their interpretations of Umayyad Caliph al- Walid II's (706-744) letter to the Garrison towns. Crone and Hinds claim that the Caliph wrote the letter as a "God's Caliph" that claimed his authority to designate his successors. Ruben, however, contends that in the letter Walid underscored the role of prophet as “a representative of God's religion, and he links the Ummayads to the prophet, not only the deputies of this religion but also as successors to this religious legacy” (Rubin, 2003, p. 88). He further claims that the letter describes the Ummayad dynasty's role as Caliph is to carry out the prophet's legacy; a legacy of calling for what is right from the Adam's time to their rule 
and beyond. Ruben thus argues that the Ummayad caliphs derived their authority from being connected to the prophet Mohammad rather than differing from him. He indicates that:

it becomes clear yet again that God and Muhammad are complementary components of the idea behind the title "God's caliph." A caliph of this kind is one who has inherited from the prophet Muhammad the mission of protecting God's religion (Rubin, 2003, p. 96).

Ibn Taymiyyah (1263-1328), nevertheless, contests these early interpretations of God's vice-regency arguing that God cannot have a Khalifa. It is because God is omnipresent, and He shares nothing with other entities. Taimiyya writes: “And one can only be a Khalifa of someone else if the latter is not there, either because he is dead or absent, or because he is in need of a Khalifa ... But none of this can be said of God; He is indeed above them all ... No-one can, therefore, be His vice-regent or take His place; because no one is like Him nor is equal to Him” (Idris, 1990, p. 104). Taimiyya condemns scholars like Ibn Al- Arabi for his interpretation that Khalifa means the deputy of God on earth where it is assumed, Taimiyya argues, that God created Adam in His image. He further criticizes Al- Arabi (1165-1240) and others who introduced "un-Islamic philosophies" to Islamic thought and tried to justify that God is identical to His creations, calling these efforts utterly erroneous.

These early interpretations of Khalifate Allah largely meant that Caliphs are rulers who follow or replace their predecessors in the legacy of prophet Mohammad. Another interpretation that is hinted in the Qadi (1988)'s fourth and fifth meaning of Khalifa, but relatively unexplored is that cultivating/inhibiting on earth or establishing justice on earth. The meaning may imply the acts of governance by God's principles. Alajmi (2011) argues that the term Khalifa attached to the word God does not mean that the person bestowed the title "Caliph of God" holds any exclusive religious authority; instead, it is a governing authority that would apply to any person. He offers an analogy between the practice of authority of a head of a family and head of a state 
in the Islamic tradition. As head of the household, usually father, is required to rule over his family in accordance to the principle of justice, a head of the state, Caliph similarly has to rule over the state to ensure justice. In this sense, a general person capable of practicing a type of rule over another person could be seen as God's caliph on this earth (Alajmi 2011). Alajmi, (2011, p. 109) further argues that "God's caliph" is not exclusive; rather it is inclusive, in that it includes any person with the capacity to cultivate the earth or rule over another person.” Alajmi’s interpretation of Khalifa, however, does not underscore God's omnipresence with the practice of Caliph's authority. He although did not explicitly write from where the Caliph would get his governing legitimacy, it could be inferred that he indicated to the people as the source of authority. It aligns with the second argument of Razek's two theories of the Caliphate in Islam.

Razek (2013) with a critical analysis of the early and medieval Islamic philosophers’ arguments on Caliphate, maintains that Muslims have adopted two theories regarding the matter of Caliphate. The first theory asserts that the caliph derives his authority and power directly from God. The advocates of this theory perceive the Caliph as the shadow of God on earth. Razek (2013, p. 31) argues that "religious scholars and poets have proclaimed from the early years of Islam that God Himself who appointed the caliph and bequeathed His authority to him.” With quotes from the famous poets and theologians, he shows how they placed caliphs above the rest of mankind, crediting them with quasi-divine qualities (Razek, 2013, pp. 30-34). The second theory of Razek is that the Caliph derives his authority from the ummah. He argues that it is ummah who designates and confers authority to Caliph to rule. Razek (2013, p. 33) quotes a verse of Al-Hutay'a (600-661) ${ }^{19}$ who addressed it to Umar ibn al-Khattab:

You are the Imam to whom, after his companion, Men entrusted the reins of authority. In choosing you, it was not you they favored, It was for their shake that they did so 
Between Razek's two theories, the second theory of vice-regency became popular in the modern Islamist political thought. The Islamist scholars of the $20^{\text {th }}$ century such as Mawdudi and Qutb argued that Caliph draws his legitimacy from ummah. For Mawdudi, the responsibility of Khalifa, the vice-regent, is to exercise the assigned authority in favor of the ultimate authoritythe God. He argues that man is the deputy of God and does not hold any authority of his own. He can exercise power only those which are delegated to him by God. Mawdudi argues that man does not have any moral right to assert his desire, but his responsibility is to meet the will of the delegated authority. He declares that it would be dishonesty and betrayal if a man claims his sovereign power or exercises God's authority in his whim or acknowledges the sovereignty of others and submits to his will. Qutb similarly argues that man gets God's authority on earth to implement His laws and transform the world as He planned. Man is given a latent power that enables him to realize the divine will and act on it. It is an honor for a human being that his generous creator selected to grant him with such an authority that is implied in the Quran, "I will make a Khalifa on earth.” No other creature, not even the Angels are bestowed with such honor. Qutb, accordingly, writes: "They [the Angels] could not see the wisdom of the Supreme will in the building and Imara [material development] of the earth, in developing and diversifying life on it, and in the realization of the will of the creator in developing, advancing and improving it, at the hands of His Khalifa, on His earth” ( in Idris, 1990, p. 108).

When Mawdudi and Qutb argue that mankind is the vice-regent (deputy) of God, they do not mean that only rulers would be the vice-regent of God as one interpretation of Idris's explanation of the concept argues. Mawdudi and Qutb also do not subscribe the other interpretation, as Alajmi elucidates, that man as vice-regent of God would enjoy the complete temporal authority. It could be inferred that the vice-regent in their interpretation rarely enjoys its 
own agency to perform worldly affairs. It is rather argued that mankind as vice-regent are entitled to accomplish duties those are prescribed by God. This extrapolation creates ambiguity: who determines, and how it is determined the extent people as vice-regent are allowed to accomplish their temporal-political affairs. Moreover, what is the implication of Qutb’s claim that God offers a latent power to vice-regent to realize His divine will?

Nonetheless, Mawdudi and Qutb’s understanding of sovereignty in Islamist political thought is largely informed by their interpretations of Khalifate Allah. In the following sections of this chapter I will discuss how, these scholars' take on vice-regency, along with other concerns, shape their theory of sovereignty.

\section{The Divine Sovereignty in Islam}

Sovereignty in modern Islamist political thought is largely derived from the Quran. The Quran frequently declares the absolute authority of God. Linguistically, sovereignty is both referred by the Arabic term al-mulk and Hakimiyyah. In dictionary terms (Khatb, 2006, p. 18), "malik is the sovereign. This is one of the ninety-nine special attributes of Allah. He is the dominion of the heavens and earth. He is the King, the ruler of Mankind.” Khatb (2006) further shows that Hakimiyyah is also used to mean sovereignty in some dictionaries. It is drawn from the word hakim that means supreme judge. According to Ibn Durayd (d. 321/939), "the hakim is the one who exercises judicial authority; a ruler or governor...and Allah the highest governor, the ruler and the supreme authority” (Khatb, 2006, p. 16). Ibn Manzur describes Hakimiyyah the following way: "Allah is the sovereign (Ahkam) of the sovereigns (hakimin), and His Quran is the hakim for and among you” (Khatab, 2002, p. 145). It denotes the supreme legal and governmental authority. Khatb argues that the term sovereignty is the translation of the Arabic term Hakimiyyah and/or al-mulk. However, sovereignty's Western definition that people are the 
ultimate sovereign significantly differs from what it means by the term Hakimiyyah and al-mulk in the Islamist thought. In response to whether sovereignty belongs to human being, a strong ruler or the God, the mid-20 ${ }^{\text {th }}$ century Islamists invariably argued for the sovereignty of God. March (2013, p. 295) mentioned:

The principle-rallying cry of the Sunni Islamist movement during the middle of the twentieth century was the proclamation of God's exclusive sovereignty (hakimiyyah) over the world, including human political action. What we might call "high Utopian Islamism" rejects any form of comparison or similarity with modern Western ideals of governance.

Although Islamists theorized and popularized the notion of divine sovereignty starting from the early $20^{\text {th }}$-century, debates on divine sovereignty were historically ubiquitous in the early Islamist political thought. Zaman (2015, pp. 390-393) offers a brief account of the contestations prevailing in the Quranic commentaries of Baghawi (d. 1122), Qurtubi (d. 1273), Ibn Kathir (d. 1373) and rulership reference of Abbasid Caliph Ma’mun (r. 813-33). However, the divine sovereignty in modern Islamist thought is theorized and popularized by Mawdudi and Qutb.

The divine sovereignty articulated by Mawdudi and Qutb carries the tradition, as discussed in the previous chapter, that politics and Islam cannot be separated. This inseparability argument is drawn from the Quranic concept tawhid, the oneness of God. Both Mawdudi and Qutb interpreted tawhid in a sense where God remains integral in all aspects of life. Any deviation from God's sphere is impermissible. They insist that the thought of any authority that shares authority with God is shirk (forbidden). It is the antithesis to the notion of popular sovereignty that is rooted in the understanding that religion and politics are two separated entities, that the ultimate political authority belongs to people who decide matters based on rationality. In the Western tradition, the emergence of popular sovereignty could be viewed as 
the deviation from the faith-inspired unity of religion and politics while in the Islamist tradition, the divine sovereignty is drawn from the oneness of faith.

Another historical lineage of Islamist political thought that Mawdudi and Qutb carry is the concept that man is God's vice-regent. However, their articulation of the concept remains highly paradoxical. It is not clear what responsibilities men are to perform as vice-regents, the deputies of God. On the one hand, it is argued that any claim for authority other than God's is, to use Qutb’s word, Jahiliya, while on the other hand, it is claimed that the rulership is arguably elected based on individual will. To what extent and in what contexts, an individual agency could be asserted remains ambiguous. Moreover, it is argued that the rulers, as God's representatives, must be ethical and religious in Islamic terms but what is the basis of the determination of religious and ethical self, seems missing from their interpretations. In the next section, I will explore and analyze the modern theorization of divine sovereignty in Islamism, including these paradoxes, propounded by Mawdudi and Qutb.

\section{Mawdudi’s Divine Sovereignty: The Unity of Faith and Politics}

Mawdudi's position on the divine sovereignty is based on his primary thesis presented in the book Four Basic Quranic Terms. In this book Mawdudi argues that the sovereignty of God over the entire universe is an indivisible entity and not amenable to sharing out in any manner whatsoever. Four basic terms such as $I l a h^{20}, R a b b^{21}, i b a d a h^{22}$, and $\operatorname{deen}^{23}$, for him, convey the

entire teaching of the Quran. It is God the only sovereign. He repeatedly underscores that “Allah Almighty is the Rabb and the Ilah; that there is no ilah but He, nor is there any other rabb, nor does He share with anyone else the qualities and attributes implied by these terms” (Mawdudi, 2000, p. 1). None but God is to give one’s ibadah, and only to Him, one should make his deen exclusive. Ibadah is meant in a broader perspective: to voluntarily submit oneself in the fullest 
sense and obey what is commanded with pleasure. With frequent citations of the Quranic verses, ${ }^{24}$ Mawdudi attempts to justify his contention that no other authority except God is to be acknowledged; God's authority can neither be compared nor be shared to any worldly person or object. Quran says: “...., And (they) were not ordered except to give their ibadah to one Ilah, only; there is no ilah except He, (end) He is free of (the taint of) what they attribute to Him by their shirk ${ }^{25 ”}$ (Qur’an, 9:31).

From a metaphysical point of view the argument that God has created the universe, and the whole creation is to submit to Him as the creator and sustainer is expected, and the adherents of monotheistic religions generally acknowledge this. However, Mawdudi’s interpretation of this metaphysics is different. He maintains that the submission to God regarding one's faith does not make one the "true" Muslim; instead, one must submit in every aspect of his life, i.e. social, cultural, and political to the God's instructions. The life beyond God’s words, beyond His revealed laws, is the life of a Taghoot. ${ }^{26}$

God is the sole possessor of all authorities, argues Mawdudi: "Godhood and authority are inextricably interconnected and are, in essence, and substance, one and the same thing” (Mawdudi, 2000, p. 24). It is indivisible. It is contrary to the popular sovereignty. Whereas Rousseau argues that the ultimate authority is indivisible from people, Mawdudi held that it is indivisible from God. The popular sovereignty emerges with the divorce of politics from religion whilst the Islamist notion of divine sovereigty emantes from the unity of faith and politics. According to Mawdudi, it is impossible that the authority over the natural entities of the universe would be in the hand of God while other entities, social and political, would be subject to the authorities of human choices. People would surrender the faith aspects to God while they would submit the political and cultural sovereignty to anyone else is not permissible to him. Rather, he 
argues, it violates God's absolute sovereignty in terms of "Supreme Sovereign, the Fountainhead of authority, the Supreme Lawgiver, and the Supreme Lord of all creation” (Mawdudi, 2000, p. 9). It is the same rationale that leads him to argue for the impossibility of the separation of religion and politics in Islam. Islam for him is a composite whole where everything centers on God's sovereignty. It is the theological sovereignty of God from which Mawdudi extrapolates his political sovereignty. Cheema (2013) argues that Mawdudi divides sovereignty into two categories: metaphysical and political-cum-cultural categories. The former, the theological one, is not generally challenged by the people while it is the latter that people do not volunteer to submit to. Political sovereignty is explicated in Mawdudi's book First Principles of the Islamic State. He denotes both theological and political sovereignty by the term Hakimiyyah that refers to God's "sole right of being the Sovereign over all this creation” (Mawdudi, 1983, p. 29).

That political sovereignty exclusively belongs to God is the foundational principle of Mawdudi's Islamic state, and described as his most "original- and disturbing- contribution” to Islamist political thought (Afsaruddin, 2007, p. 304). Mawdudi does not disagree with the definition of sovereignty in the Western political thought that sovereign is the ultimate lawgiver, and no law binds him; the good and bad are determined by the way the sovereign defines those; he is the absolute above all aberrations and errors. He, however, differs with regard to determination of the sovereign. He argues that the ideal sovereign is impossible to find in the world. Whatever power a monarch holds or whatever way a leader in a democracy rules a territory, they are constrained to some points. He, accordingly, argues that "the experts of political science, [who] imbued with this ideological sense of sovereignty, have endeavored to locate the possessor of such sovereignty in human society, [...] have invariably failed" (Mawdudi, 1960, p. 16). “Only God's power is unrestricted and without constraints. He has to 
refer to none and to render account to none” (Quran, 21:23); "He is the source and fount of all authority” (Quran, 23:88). Thus, sovereignty belongs to God and God alone.

From this ground, Mawdudi rejects the argument that claim for the human agecy to pursue temporal affairs. He argues that if some human agency is invested with this superhuman mantle of sovereignty, overlooking the inherent shortcomings of it, it would not have any service to a human being. For him, human beings, individually or collectively, cannot bear such a huge power of sovereignty, that is an unlimited power to enforce his will over large numbers of people. Such "human agency historically has invariably resulted in injustice and maladministration of the most contagion type” (Mawdudi, 1960, p. 17). He cites Quran to support his conclusion: "He who obeys only the dictates of his selfish desires or inclinations or, rather regards his personal views as the only law, in effect makes his self his ilah instead of God" (Quran, 25:43). The sovereignty of God thus "limits human agency and circumscribes it within a supreme revealed law which it can neither alter nor interfere with” (Mawdudi, 1983, p. 25). Those who regard customs or rituals as permissible without having any divine authorization are accused of claiming for a share in the divine authority (Mawdudi, 2000, p. 19). Therefore, the Quran declares that no creature has the right to impose his will or worlds on other creatures and that is the right exclusively reserved for God. Quran says, "Verily, His is the Creation and His is the Law" (Quran, 7:54). The Law is so extensive and absolute that "the believers cannot resort to totally independent legislation nor [can] they modify any law which God has laid down, even if the desire to effect such legislation or change in Divine laws is unanimous" (Mawdudi, 1960, p. 21). From this standpoint, Mawdudi goes on to argue that the sovereignty in the Islamist political thought is different from the popular sovereignty in the Western political thought. The 
philosophical foundation of Islamic democracy, therefore, is distinctive from the Western notion of democracy.

The democracy in an Islamic state that Mawdudi would champion could be what he calls “democratic caliphate” or "theo-democracy.” It fundamentally differs from the Western liberal democracy on the ground of sovereignty. Unlike liberal democracy, theo-democracy is based on the belief that sovereignty belongs to God alone. In Mawdudi's words: "the difference lies in the fact that whereas in the western democratic system a democratic state enjoys the right of absolute authority, in our democracy the Khilafat is bound to keep within limits prescribed by the Divine Code” (Mawdudi, 1960, p. 21). The Islamic state could not accept the relativity of truth, which is an integral part of Western democracy (Nasr, 1996). It is so central to the Mawdudi's theodemocracy that no compromise on God's sovereignty is possible. In the words of Khurshid Ahmad, the place of sovereignty in Mawdudian democracy resonates the following way:

We have certain reservations about Western democracy on ethical/moral principles, especially over where sovereignty lies. But that does not mean that Muslims are "fascists." Muslims believe in the rule of law, human rights, shura, all of which are also important to a democracy. We have problems of accommodating democracy, but our faith is not antithetical to it (Nasr, 1996, p. 88).

The theo-democracy rests on the Quranic concept of Khilafah or the "vice-regency of humans” in relation to God, revealed in Quranic verse: “God has promised such of you as have become believers and performed good deeds that He will most surely make them His vicegerents on earth” (Quran, 24:55). In Islam, for Mawdudi, the term sovereignty of humans is not meant in an absolute sense. God is the ultimate sovereign that none has to share, while human being is allowed to hold limited power and authority to exercise in favor of God. They are merely viceregent of God. It is neither similar to the king's divine authority to rule nor an authority an individual or group of people achieve as a birth right. It is "the collective right of all those who accept and admit God's absolute sovereignty over themselves and adopt the divine code, 
conveyed through the prophet” (Mawdudi, 1960, p. 20). Khilafah is not limited to a privileged class of people. Instead, it is contingent upon personal religiosity, and virtuous conduct and "every Muslim who is capable and qualified to give a sound opinion on matters of Islamic law is entitled to interpret the law of God when such interpretation becomes necessary” (Mawdudi, 1960, p. 25). It is further argued that in a society everyone is the Caliph of God and an equal participant in the Caliphate. Thus, the power cannot be seized by a single clan or class, at least it becomes difficult. However, Mawdudi argues that his theo-democracy is neither democratic nor theocratic in the Western standard. It is not democratic because it rejects the philosophy of unlimited popular sovereignty of Western secular democracy, and it is not theocratic, because a religious class akin to the Christian tradition does not rule it and imposes their laws in the name of God's. Rather, theo-democracy is ruled by the whole "community of Muslims including the rank and file ... in accordance with the Book of God and the practice of His prophet” (Mawdudi, 1960, pp. 23-25).

Mawdudi's repudiation for popular sovereignty does not deter him from arguing for a viable theo-democracy in Islam. He criticizes the moral predicament of Western democracy and argues that Islam's ethical and moral teaching could fill that gap. For him, popular sovereignty as practiced in Western democracy has several drawbacks. It provides enormous power to a class or group of people who establishes perpetual domination over others. Only those are from the wealthy and privileged families can ascend to the top of the political power hierarchy while the rest of the population "have to delegate their sovereignty to their elected representatives so that the latter may make and enforce laws on their behalf” (Mawdudi, 1960, p. 26). Such democracies are devoid of ethical and moral considerations where a small, powerful-privileged group makes and implements laws that meet their narrow self-interests. It breaches the social contract of the 
liberal democracy that promises to ensure common goods in exchange for the submission of individual will. It, thus, also violates the nature of human equality. Mawdudi argues that this democracy based on popular sovereignty "cannot serve the overall best interests of humanity or contribute to its moral and ethical advancement. Such a situation often leads instead to the enslavement of humans to their base desires and passions” (Mawdudi, 1960, pp. 26-28).

Mawdudi although did not mention anything comparable to the social contact in the Western tradition, it could be inferred that he prioritizes the contract between God and the human being established through the divine sovereignty in Islam, over any worldly contract. Unlike the social contract theories in the Western political thought, Mawdudi prioritized the covenant submission over the people's contract. He does it from the moral ground as his assumption, similar to Qutb, that the Western post-enlightenment political thought that deviated from God's unity brought deprivation, corruption, and serious moral crisis. This assumption could be partly compared to the Hobbesian state of nature where human being by nature acts for meeting an individual's self-desire. Mawdudi, as Qutb, does not have faith in reason-inspired morality of the West. He argues that it failed to prevent racial, economic, and other discriminations in Western societies. It could be inferred from Mawdudian thought that faith-inspired morality could better establish a stable Islamic society. In a society, where individuals are in a relation of brotherhood with others that is not only a mundane requirement but a religious obligation. Therefore, a better social cohesion or social contract in Islamic societies could best be achieved through imposition of moral code revealed in the God's texts. He held that the limits God imposes on the human through His revealed laws prevent the moral degradation of humans and safeguard a moderately balanced life in compliance with God laws (Afsaruddin, 2007). Articulating "merits" of Zakat, ${ }^{27}$ veiling, and $h u d u d^{28}$ penalties in Islam, Mawdudi attempts to elucidate how these laws 
contribute to establish economic equality, ensure the protection of women and reduce the rate of crime, ultimately contributing to the establishment of a more moral and balanced society. The essence of his thought is best captured by the popular slogan, "Rule of man over man is exploitation; submission to Allah the Creator is the only way to emancipation” (Nasr, 1996, p. 88).

The state Mawdudi imagined and worked for is an Islamic state; he calls it the ideological state (Mawdudi, 1977). For him, the ideological state is a state that is established exclusively based on Islamic spiritual and moral principles, completely separated from nationalism and associated Western ideas. The fundamental basis of his Islamic state is the unquestionable acceptance of divine sovereignty. Nasr asserts:

In defining the Islamic state, Mawdudi attempted to accumulate the Islamic doctrines of tawhid (unity of God), understood as the absolute sovereignty of God, risalat (prophecy), understood as the ideal Islamic state; and Khilafat (caliphate), understood as a viceregency of mankind on behalf of God and, hence, the reproduction and perpetuation of the Islamic state in the post-prophetic era, to support his position (Nasr, 1996, p. 89).

The fundamental principle of divine sovereignty is that the universe and all its attributes belong to God Who alone is its ultimate Sovereign. "No individual, family, class or nation, not even the whole of humanity can lay claim to sovereignty, either partially or wholly. God alone has the right to legislate and give commands” (Mawdudi, 1977, p. 7). Mawdudi used Quranic verses (12.40 and 5.44) to argue "sovereignty (hakimiyyah) rests only with God. God alone is the law-giver. No human being, not even a prophet, has the right to command and prohibit on his own” (Mawdudi, 1960, p. 27). In a state, human beings, the servants of God, do nothing but collectively work to carry out His will and purpose.

This collective performance of God's duty, Mawdudi argues, human being does not accomplish in an authoritarian governance or through the selection of the rulers to govern. With a historical explanation from the rightly guided caliphs to later leaders, he contends that Islam 
never supported the selection or forceful occupation of a leadership position. In an Islamic state, "the election of its Head depends entirely on the will of the general public and nobody has the right to impose himself forcefully as their leader (Amir)" (Mawdudi, 1960, p. 37). Mawdudi declares that the election should be with the free will of the masses in Muslim societies. This declaration of Mawdudi seems paradoxical. On the one hand, he argues that human being does not enjoy their own agency to assert, while on the other, he maintains that the leadership is elected by individual's will. Mawdudi, thus, argues for a limited human agency that is alternative to Western political thought. Unlike Rousseau who argues for the absolute human agency in all facets from faith to politics, Mawdudi contends that human being has the agency to decide on matters that are not clearly dictated in Quran and Hadith. They are entitled to decide on those temporal affairs in the process of shura, and through ijtihad (independent interpretation of legal sources). However, the chief condition is that it must be guaranteed that those pronouncements do not undermine the revealed texts. Mawdudi has seen shari'a as a body of codified laws that need to be implemented by the rulers in an Islamic state. While referring to God's laws, Mawdudi's sovereignty has some similarities to Bodin's. Mawdudi and Bodin argue that the rulers can make laws and execute those unless they contradict the laws of nature/God. ${ }^{29}$ Mawdudi's laws of God, however, are codified while Bodin’s laws of nature are not, that led many scholars to interpret that Bodin merely mentioned them to limit the ruler's absolute power. It could be inferred that for latter, the natural law is a temporal requirement whereas it is a fundamental religious obligation for the former. Mawdudi, nevertheless, unlike both Hobbesian and Bodinian thought, believes in the democratic governance where rulers are subject to the laws not only specified by God but also the laws, they arrive at through ijtihad. 
The restriction on individual will is also revealed in the Quran, regarding those few who are chosen to be God's representatives to rule: “Allah has promised to those among you who believe and do righteous deeds that He will assuredly make them succeed (the present rulers) and grant them vice-regency in the land just as He made those before them to succeed (others)” (Quran, 24:55). Mawdudi often draws on this verse. The people who are entrusted with the responsibility of governing the state, Mawdudi argues, should remember that they are not authorized to enforce their orders or enforce their own will on others. They should not attempt to enslave people of other nationalities. They are entitled neither to seek submission from other rulers nor to submit themselves to others. Rulers should not rule for self-glorification. They must have the feeling that the burden of rulership on them is to enforce divine law and ensure social justice to God's creation. Mawdudi identifies the vice-regent to rule as the guardians of the Islamic state- the executive branch. The "executive must be obeyed on the condition that it obeys God and His Prophet and avoids the path of sin and transgression” (Mawdudi, 1967, p. 33).

Mawdudi also thought that the state should have a legislative branch and a judiciary. Fiqh, the body that prescribes and resolves disputes, would work as the legislature. However, being restraint by divine code, it cannot legislate something that contradicts the sayings of God and His Prophet. Mawdudi maintains that those who do not adjudicate according to divine law are unbelievers, unjust, and rebels (Mawdudi, 1960). The legislative branch, however, can only formulate its own laws where there is no guidance in the Qur’an, Sunna (the practices of the Prophet) or from rightly guided caliphs (Mawdudi, 1967). The function of the judiciary is to confirm that the divine code is maintained and not to be violated by any means. But he wanted to limit their function only to advising the executive. The actual functions of governance in an 
Islamic state, Mawdudi delegated to de facto state’s executive body. They can perform their works as long as those do not infringe the sovereignty of God. However, as the vicegerent of God, the executive could exercise ijtihad (independent inquiry to establish the ruling of the shari'a). Although traditionally ijtihad had been the domain of the ulama, Mawdudi favored curtailing their power and delegate it to the state (Nasr, 1996, p. 90). He writes, "Man’s status in the universe having thus been determined, it follows logically that he has no right to lay down the law of his conduct and decide the right and wrong of it. This is a function which properly belongs to God" (Mawdudi, 1953, p. 33).

The above discussion reveals that it is the state and its machinery, divided into different branches, that are at the center of Mawdudi's political thought. He takes the Prophet's rule in Medina as the model of the Islamic state that for him was a centralized body politic with an omnipotent executive branch (Mawdudi, 1967, p. 122). For Mawdudi, Prophet was the embodiment of both spiritual and political unity, he never considers those as separate entities. Individual agency is not clearly recognized in the Mawdudin Islamic state. Nasr (1996) argues that according to Mawdudi, the individual expression would be truncated by the primacy of the legal and, by implication, political sovereignty of God so that it cannot counter the divine mandate of the state. It, nonetheless, paves the way for the state to emerge possibly as the supreme authority and the prime political actor with the embodiment of the divine will and man's vice-regency. Individual, therefore, is to submit his own vice-regency to the state which is the expression of a collective vice-regency (Mawdudi, 1967, pp. 81-82). The individual would be legally bounded by the state, backed by the full forces of religious law and the significant power of the collective vice-regency (Nasr, 1996). Mawdudi with a Quranic interjection concludes: “O 
ye who believe! Obey Allah and obey the messenger and those of you who are in authority” (Quran, 4:59).

\section{Qutb's Divine Sovereignty: A Reaction to the Western Modernity}

Sayyid Qutb, a contemporary of Mawdudi, articulated the divine sovereignty thesis more extensively. He argues that in the Islamic state, God is the ultimate lawmaker and the source of all authorities. Qutb unambiguously declares that the Islamic faith liberates mankind from each other's enslavement and confirms that God alone owns all Lordship and Godhead throughout the universe (Qutb, 2000, p. 146).

Qtub primarily discusses the concept of sovereignty in his book in the Shade of the Quran (Fi Zil al Qur’an) and Milestones (Ma’alim). He argues that authority and command rest with God alone. He cites a number of Quranic verses to substantiate the contention: "He governs all affairs from the heavens to the earth" (Quran, 32:5). "He to Whom belongs the domination of the heavens and the earth, no son has He begotten, nor has He a partner in His sovereignty” (Quran, 25:2). “The command rests with none but Allah” (Quran, 6:57). It is declared in the Quran that even the Prophet Mohammad (PBUH) does not share sovereignty with God: "I am but a man like yourselves. It is revealed to me that your God is One God” (Quran,18:110). Predicating on the Quranic articulations, Qutb asserts that the ultimate sovereignty (hakimiyyah) belongs to God exclusively Who created the universe and maintains it and on Him, all authority, political or other, rests. However, Qutb describes divine sovereignty that appeared in the Quran the following way:

Authority belongs to the exalted God exclusively by virtue of His divinity. For sovereignty (hakimiyya) is among the characteristic features of divinity. Whoever lays a claim to sovereignty - whether it is an individual, a class, a party, an institution, a community or humanity at large in the form of an international organization-dispute the primary characteristic of His divinity. And whoever does so is guilty of unbelief in the most blatant manner.... Laying claim to this right [to sovereignty] does not necessarily 
take a particular form, which alone might be deemed to remove the claimant from the fold of 'the true faith' (al-din al-qayyim [Quran, 12.40]).... Rather, one lays claim to it ... simply by ... deriving laws from a source other than [God].... In the Islamic system, it is the community that chooses the ruler, thereby giving him the legal right to exercise authority according to God's law. But [this community] is not the source of sovereignty which gives the law its legality. God alone is the source of sovereignty. Many people, including Muslim scholars, tend to confuse the exercise of power and the source of power. Even the aggregate of humanity does not have the right to sovereignty, which God alone possesses. People only [have the right to] implement what God has laid down with His authority. As for what He has not laid down, it has neither authority nor legality (Zaman, 2015, pp. 393-394).

The basis of his divine sovereignty, like Mawdudi, is the Quranic concept tawhid. It declares the oneness, the unity and the uniqueness of God. In the classical period, the concept was used to mean the philosophical considerations defining the essences and attributes of God, and the legitimacy of Caliphate’s political institutions (The Oxford Dictionary of Islam, 2003). However, Qutb’s interpretation of it, in line with other Islamist ideologues such as Ibn Taymiyyah, Muhammad ibn Abd al-Wahhab (1703-1791), Abu Ala Mawdudi, is more political and monolithic. He defines tawhid as "human response to God, whereby society is to reflect divine unity through unanimous submission to God's revealed will, both privately and publicly” (The Oxford Dictionary of Islam, 2003). His interpretation of tawhid is revealed in the following passage:

Islam begins by establishing the principle of the Oneness of Allah (Tawhid), as it is from Him that Life issues and unto Him that it turns. "Say: God is One. ..” (Quran, 112:1-4). Accordingly, there is no controversy or doubt about the origin of this universe. . .Out of the Will of this One God, the whole existence has been created in the same unified manner. . . There is no intermediary between Creative Will and the created beings, nor are there multiple ways of creation, but it is the Will referred to in the Quran by the word 'Be' that prevails. . . The One God reigns sovereign over all beings, to Him they turn for refuge in this life, and in the Hereafter. . .The universe, with its diverse ramifications, has one origin from which it is issued. . By one Supreme rule, this universe has been thoroughly administered in a manner that precludes any collision among its parts. . . ( Pasha, 2013 , p. 110).

Qutb’s concept of hakimiyyah is derived from the comprehensive divine unity, associated with worship. To him, the theories, commandments, laws, rules of worship and social relations in 
an Islamic community all are drawn from the doctrines of Islam. The relationship between the Creator and His creation, one creature with another, individual with the state, and so forth is determined and facilitated based on this comprehensive unity of God. Nothing is separated from this God's uniformness. Islam is "a system in which all spheres aimed firstly and finally to fulfill the meaning of worship; in the system of government, economic, criminal law, civil law, personal status law, and all laws and codes aimed to fulfill the meaning of worship" (Khatab, 2002, p. 152). The entire universe created by the supreme will of God and is run by His law. All creatures are in harmony, God in the center of all. The whole universe is constant and regulated by laws, revealed in the holy Quran which is also constant. The human being needs to locate itself within this universe and its laws for its harmonious functioning. Under God's metaphysical presence and harmony human being locates them. In a Lockean way, Qutb’s contention could be interpreted that human being is God's property and under a single owner all are equal and free. One cannot own or subjugate others as Locke points out: "all men by nature are equal” because of God's decision. The relationship among people in the community in Qutbian thought is also developed in accordance with God's laws and dictations.

Qutb argues that other laws and authorities would jeopardize this harmony. Therefore, the nature and meaning of hakimiyyah cannot be analogous to the sovereignty in the Western tradition where people are the ultimate sovereign. Euben claims that Qutb’s divine sovereignty is a reaction to the popular sovereignty of the Western political thought. Qutb challenges the postenlightenment rationalist thought because it undermines God's supremacy over the universe. For him, the assumption of all such man-made sources of authority is that sovereignty is independent from the spiritual authority. In Euben’s words: “Qutb’s investment in divine sovereignty is formulated precisely in opposition to modern rationalist understandings of knowledge and the 
marginalization of the revealed truth they entail” (Euben, 1999, p. 141). Qutb’s critique of popular sovereignty emanates from the moral bankruptcy he finds in the rational, humane interpretations of reality. The exclusion of absolute God's authority from the modern thought, Qutb declares, paves the way of shared-multiple authorities those engage in conflict among themselves and engender moral crisis. For Qutb, a multiplicity of will, authority, rule and judgment of the Western political thought are the opposite to the doctrine of tawhid, the basic principle of Islam. From this concept of tawhid, Qutb argues for the impossibility of separation between religion and politics in Islam. To him, Islam by nature is a political religion (Khatab, 2002). The inseparability of religion from politics is a basic principle of an Islamic state. For Qutb, the theory of government in Islam is exclusively based on tawhid: "Any other theory would be shirk (idolatry) and kufr (unbelief)” (Khatab, 2002, p. 155).

It naturally poses a challenge to all other systems that attribute sovereignty to people in any form or shape. According to Qutb, it is a challenge to any human condition where sovereignty is ascribed to people. Islam never approves any man-made law; no human being can be placed over the Lordship of other people. For Qutb, obedience to man-made laws take people out of Islam, and it is the objective of Islam to eradicate man-made laws for the true human liberation (Qutb, 2000, p. 148). He writes, “To proclaim God’s authority and sovereignty means the elimination of all human kingships and to establish the rule of God, the Lord of the universe.” Qutb cites from the Quran: "He is alone God in the heavens and God on earth” (Quran, 43:84); "all judgment rests with God alone. He has ordered that you should worship none but Him. That is the true faith, but many people do not know it” (Quran,12:40). All people ought to know that Islam means to accept the creed "La ilaha illa Allah" [There is no God but Allah] in its deepest sense of it. Qutb insists, "every aspect of life should be under the 
sovereignty of God, and if those rebel against this divine sovereignty and usurp it for themselves, they should be opposed” (Qutb, n.d., p. 35). It should be believed in hearts and minds that shari' $a$ is a divine and universal law and it should not be compared to other laws. The establishment of shari' $a$ as a sole source of authority is the complete submission to God, argues Qutb. Shari'a is the compilation of regulations and prohibitions derived from the Qur'an and Hadith (Qutb, n.d.). It appears and widely understood from Qutb’s writing that shari'a is a collection of codified laws drawn from the Quran and Hadith. Euben, however, argues that in Qutbian understanding, shari'a encompasses but is not limited to matters of positive law as it is understood in the Western political thought, it is, rather, perceived as impeccable legislation that covers nearly all aspects of human existence. Shari'a "covers every possible human contingency, social and individual, from birth to death, including matters relating to administration, justice, morality, ritual washing, the dispensation of property, and political treaties” (Euben, 1999, p. $62)$.

In Qutb’s book Milestones, he argues that Jahiliyyah, ${ }^{30}$ the champions of man-made laws tend to find out a way that undermines the God's system and subdue the Islamic laws in the name of "reconstruction of Islamic law." He, therefore, asserts that Muslims must expose all these treacherous tactics and strive to establish God's sovereignty (Qutb, n.d., p. 43). For Qutb, faith and politics are inalienable, in both cases the fundamental is the acceptance of God's sovereignty, ratifying Him as the only source of laws. If anyone derives laws from a source other than God, his acceptance, the oneness of God as a faith is not completed. He asserts: "in a Muslim society the beliefs and ideas of individuals, their devotional acts and religious observances, and their social system and their laws, are all based on submission to God alone. If 
this attitude is eliminated from any of these aspects, the whole of Islam is eliminated” (Qutb, n.d., p. 78).

Qutb (2000, p. 147) further argues that although the establishment of the rule of God in the earth is done by people, this does not mean that people's authority is recognized. He sought to distinguish the Islamic sovereignty from that of the medieval Christian sovereignty where men became God’s spokespersons. The way Protestant reformation destabilized God's authority in the Christian tradition, was not possible in Islam, Qutb argues. Because in Islam religion and politics are by no means separable. In Islam, he held that God's command is established if His laws are enacted, and all worldly matters are adjudicated based on His revealed texts. The sovereignty of God is the center of Qutb's thoughts. His famous declaration that the world is in the state of “jahiliyyah,” was an upshot of defiance of God's sovereignty. According to him, society is jahilli when it has repudiated Allah's hakimiyyah and prioritizes Western philosophy that undermines God’s sovereignty.

The enlightenment inspired modern thought for him is jahiliyya since it entirely dethrones God in the name of maintaining peaceful social and political order. His criticism of modernity is that modernity is the negation of God's command. Qutb assumes a battle between Islam and jahiliyyah. Pasha (2013) describes this compartmentalization arguing that in Qutb’s thought there are two historical paths: the path dictated by human themselves or the path to God. Western modernity, the flagbearers of the latter path, in Qutb’s view have given up the God's path to prioritize the human articulated rationality. It obeys the human laws in place of God's. In contrast to the modernist thought, Qutb contends that human freedom is achieved when they surrender all authority to God only. It, for him, not only offers human beings the ultimate freedom but also saves them from the likelihood of their enslavement by each other. 
For many, Qutb’s rejection of “Godless” Western modernity is a part of his attempt to Islamize modernity (Sivan, 1985). He replaces human authority with hakimiyyah which for him carries no trace of human innovation and offers complete social harmony. The social contract of Western tradition becomes a divine compact. Qutb discards both Hobbesian brutish nature of the state, and Weberian nature of the political authority of a modern state. His Islamic ideal of state authority is unified under God's guidance. In the process, he delegitimizes the traditional jurists' authority of interpreting scriptures. Robinson (2009, p. 340) notes, "The authority of much scholarship from the past, has been rejected; the authority of the traditional interpreters, the ‘ulama, has been marginalized.” It is not that only Islamist like Qutb or Mawdudi’s interpretations of scriptures dismantled ulama authority. Rather, Robinson shows a range of factors that contributed to the crisis of authority such as the growth of mass education, availability of texts, growth of new Islamist social movements. It leaves, for Qutb, the Quran and Hadith as the ultimate sources of authentic understanding for human action. The individual emerges as the growing interpreter of divine texts for their religious practices. It has engendered a new crisis that Burckhardt in a different contest called the terrible "simplification of faith" (Pasha, 2018). Qutb’s interpretation and the returning to the original texts eliminate the lived experiences and cultural imaginations of religiosity across the world. Religion becomes the stricter adherence to a particular "codified practices of faith," and it sharply divides the "true" and "nominal" believers. His elimination of jurists is a radical reinterpretation of the intellectual history of Islam through two major normative shifts (Pasha, 2013 ): firstly, it is a departure from the traditional dominance of law and jurisprudence, and secondly, it emphasizes the significance of political power in establishing a "city of God." It could be defined as a process of democratization of authority in interpreting revealed laws as Qutb empowers individuals with 
that authority. Pasha (2018, p. 7) argues that "Qutb can be regarded as a principal actor in the advancing decentralization and democratization of Islamic interpretations.” This argument is not new but Qutb inherits it from the advocates of Salafiya movement in $19^{\text {th }}$ century Islam.

Nevertheless, human being is not entitled to formulate laws by themselves. The attempt to do that is jahiliya. Any man-made system of governance is jahiliya (ignorance to God). Therefore, any form of governance namely, democracy, communism, liberalism, socialism, nationalism that overtly ratify human severity are “jahiliyyah.” Qutb maintains that such systems, "all share one common truth: their way of life is not established on complete submission to Allah alone. In this respect, they share the same characteristic of other societies, the characteristic of jahiliyyah” (Qutb, 2000, p. 131).

Based on this passage of Qutb, Zaman (2015) claims that Qutb’s take on divine sovereignty is a modern view for two reasons. First, he coins the word hakimiyyah from the Quranic term hukm that generally means authority or judgment. Second, Qutb uses hakimiyyah as a political term that conveys the message that God is the "exclusive locus and source of all power.” It is the heart of all concepts in Islamist politics. In an Islamic state, the failure to submit to the sovereignty of God is tantamount to unbelief as the Quran says: "those who do not judge according to what God has revealed are unbelievers” (Quran, 5.44), “wrongdoers” (Quran, 5:45) and "ungodly" (Quran, 5:47). Qutb does not approve of the institutional separation of authority in an Islamic state. “The Western idea of separation of institutional spheres, leaving Caesar’s sovereignty to Caesar and God's sovereignty to God is a direct challenge to God” (Bergesen, 2008, p. 19). This assumption in a democracy is not ideal nor perfect; it is heretical, drag worshippers away from God by establishing another deity (the state) that requires worshipping (obeying its laws) (Bergesen, 2008). March (2013) summarizes Qutb’s idea of sovereignty 
saying that he based on the common belief in God's cosmic or creative sovereignty proposes an uncompromising insistence on God's absolute normative and legislative sovereignty. It remained the most influential Islamist thought in the $20^{\text {th }}$ century.

While Mawdudi offers a system of Islamic governance and accepts the idea of nationstates, Qutb’s engagement with nationalism and nation-state is ambiguous. Similar to Mawdudi, he rejects the idea of nationalism from the ground of the idea of the ummah, which is transnational, non-territorial. ${ }^{31}$ Ummah embodies the universality of Islam. The Muslims are identified primarily based on the message of ummah - Islam as a faith binds the community. It is a supra-national entity where people of different ethnicities, languages, and territories are unified through the submission to one God. Islamic nationalism, for Qutb, is fundamentally different from the Western secular nationalism. He rejects secular nationalism on two grounds. First, secular nationalism accepts the sovereignty of people that means multiple temporal authorities are acknowledged. It, on the one hand, enhances the possibility of disharmony in the universe, and on the other, discards tawhid, the basic principle of Islam. Secondly, upon rejecting the spiritual relationship with God, secular nationalism facilitates the basis of human connections those are very different from the Islamic basis of individual connections. What connects people in a secular nationalism? It is generally a range of moral and ethical values that may be originated from the religions or other sources, equally work for the collective human "good.” These values are not ultimate, unchangeable or agreed on their completeness.

In contrary, the basis of Qutb’s Islamic nationalism is definitive. It is the unconditional submission to hakimiyyah. Pasha (2018) argues that in contrast to secular humanism in the Western nation-states, Qutb constructs his own version of humanism as the basis of connecting the individual to God, and the individual to individual. Qutb’s humanism wants that all racial and 
ethinic segregations are eschewed, and a natural harmony of the revealed massege and human activites is established. When all submit their Will to God, they become equal and harmonized. They are ruled by the same divine laws (shari'a) from the same authority with a view to ensuring God's satisfaction. In the process, human being engages in a relation of brotherhood. For Qutb, this relationship is more lasting and humane than that of the man-made relations. He argues that the acceptance of divine sovereignty opens the unlimited possibilities for the human prosperity. It is the similar and necessary link what Mawdudi argued for, the link between din (faith) and dunya (worldliness). Rejection to it is jahiliyyah.

In the Islamic view, all human beings are one nation. Thus, there is no race or homeland (watan) that can exploit other races or the homeland of others ... When Islam abolishes both those geographical bounds and racism, upon which the idea of the national homeland is established, it does not abolish the idea of homeland completely but preserves its righteous meaning, that is the meaning of association, brotherhood, cooperation, system, and the meaning of the common goal with which the group is associated. This makes the idea of homeland an idea in the consciousness, not a piece of land. In the shelter of this idea, the peoples of all races, colors, and territories can associate as people of one homeland. They are brothers in the name of Allah, cooperating for their welfare and the welfare of humanity as a whole. This idea is Islam - 'The true believers are brothers' [Qur'an, 49:15] . . . Here the idea of Islam replaces the idea of a homeland in its righteous meaning ... What emerges from this [idea] is the feeling that every territory under the shelter of Islam is the homeland of all Muslims and they are all its citizens ... (Khatb, 2006, p. 122)

Qutb's argument for an extraterritorial idea of a homeland for the Muslim community defies the idea of the nation-state. Unlike Mawdudi who accepts the nation-state as an unavoidable reality and offers a blueprint of an Islamic state with the governance under the “theo- democracy,” Qutb’s take on it seems ambiguous. Mawdudi articulates the art of governance with the division of labor such as the specific functions of the executive, judiciary whereas Qutb's writing is limited to the argument for a righteous community of believers without any elaboration on how the community should be governed. Qutb argues that the realization of Islam is a societal affair and that requires volunteer human participation. He, 
however, did not offer any mechanism of human participation, perhaps something akin to the social contract in the Western political thought. It can be assumed that in Qutbian thought where the human autonomous agency is not acknowledged, the relations among individuals in the community should be determined by Islamic brotherhood. An omnipresent God's ethos binds all. Islamic community, Qutb argues, is "not related by nature to a particular time; rather they are based on a truth that has come to humanity from a divine source, from a realm beyond the human, and beyond material existence” (Qutb, n.d., p. 120). It could also be inferred that Qutb did not deny the inevitability of nation-states where human beings collectively act as viceregents of God to govern the state. They would simply remain the deputies of God. People would only execute God's laws in favor of Him and are not entitled to formulate laws or reinterpret God's laws. Qutb argues that changing circumstance does not change the essence of Islam. The fundamental teachings of Islam remain the same across time and place. The argument of reinterpreting revealed laws is Jahiliya (Qutb n.d.). In this regard, he departs from the contentions of his Islamist predecessors such as Jamal al Din al Afghani, Mohammad Abdhu, Rasid Rida, and others who argued that there is no contradiction between reason and revelation. In contrast, Qutb’s take is, as Euben articulates:

Granting reason such wide scope is inimical to Qutb's insistence that unchecked reason will destroy both the substance of and authority behind revealed truths. Thus, while Afghani and 'Abduh accept both the objectivity and truth of modern knowledge, Qutb seeks to unmask such claims as vehicles for the erosion of divine authority and expression and acceleration of Western influence (Euben, 1999, p. 116).

Pasha's (2018) reading of Qutb is that he too recognizes the unavoidability of a nationstate to ensure both social cohesion and religious belonging. For March (2010), the "realistic utopia” of Qutb although emanated from the divine sources, is this-worldly. He argues that Qutb's consistent discussions on salaf (first generations of Muslims) do not contend for a unique sacred moment, neither do they close the door for epistemic interpretations of the sacred book; 
rather they provide a realistic possible model to develop an Islamic social order through the actions of distinctly ordinary humans. Developing a social order [within a nation state] becomes the responsibility of the individual believers. This responsibility is derived from the God-gifted features of conscience, reason, and self-understanding. It becomes an integral part of religious practice. However, Qutb will not allow humans to interrogate the metaphysical presence of God which requires to acknowledge that God alone is All-Knower. He further notes that it is impossible for the human to "adopt a privileged stance in the endeavor to know where any practice that authenticates the supremacy of human powers is shirk” (Qutb, n.d., p. 8). Individual responsibility is not only to establish God's laws on earth and develop a community of the faithful but also to stop any activity that questions God's sovereignty.

\section{Conclusion}

The divine sovereignty of Mawdudi and Qutb primarily stem from their interpretations of Quranic concept tawhid. The contention is that the oneness of God must be maintained not only in the individual's theological aspects but also in social, cultural and political facets of them. Rejecting the separability thesis in Islam that argues that the practices of religion and politics as two separate entities could be determined in the historical intricacies of Islamic governance, Mawdudi and Qutb maintain that this separation thesis is impermissible in Islam. For them, it gives the individual a share to God's ultimate sovereignty. For them, any thought that challenges God's oneness contests the absolute sovereignty of God. It is, therefore, inferred that Mawdudi and Qutb’s divine sovereignty emanates from the contention that faith and politics are inseparable while popular sovereignty emerges with the church's separation from politics.

Mawdudi and Qutb reject popular sovereignty basically on moral ground. It is argued that Western countries failed to establish a just society because they undermine God's sovereignty. 
People's sovereignty empowered a small privileged class in the West that enslaved others contributing to societal chaos and moral crisis. Mawdudi and Qutb maintain that Islam's divine sovereignty could cure this moral catastrophe. They further argue that popular sovereignty that centers on worldly social contract also failed to maintain its promise of establishing a wellbalanced, just society. Thus, it is claimed that Mawdudi and Qutb contend for a social contract that is based on faith-inspired Islamic brotherhood. God would be the source of legitimacy of all relations such as the rulers and ruled, in Islamic communities. Mawdudi and Qutb claim that individuals are allowed for a limited practice of their agency in Islamist polity where revealed texts do not have clear indications. They regard the revealed texts (shari'a) as the codified laws of Islamic state where state would enforce shari'a from above. Mawdudi and Qutb's theory of divine sovereignty is contested by many contemporary Islamist scholars. Ghannouchi's argument for the sovereignty of ummah is the most prominent of them. In the next chapter I will illustrate Ghannouchi’s interpretations of Islamist sovereignty. 


\section{CHAPTER IV: THE SOVEREIGNTY OF UMMAH: GHANNOUCHI'S THEORY OF}

\section{SOVEREIGNTY}

\section{Introduction}

There has been a long debate on sovereignty in Islamist political thought in various times and contexts. It started after the death of Prophet Mohammad (PBUH) in 632, sustained during the regimes of four rightly guided Caliphs and Islamic dynasties and Empires. It, however, became extremely contested when Muslim majority countries started to adopt modern nation states. The question of whether to accept the nation state's popular sovereignty or how to reconcile the essence of popular sovereignty with Islam's divine sovereignty emerged as the most debated issue in modern Islamist political thought. The dominant argument is that God's sovereignty cannot be compromised in Islam because it is not only an integral part of Islam as a religion but also an indispensable component of Islam as a political ideology. This understanding is theorized and popularized by some Islamist scholars and ideologues, namely, Abul A'la Maududi and Syed Qutb as discussed in the previous chapter. Nevertheless, other scholars and ideologues started to interpret sovereignty in Islam differently. ${ }^{32}$ The most celebrated among them is Rachid Ghannouchi, an intellectual vanguard and current president of Tunisia’s Ennahda party. He interprets the absolute divine sovereignty in Islam from a different viewpoint and offers an alternative within Islamist thought-the sovereignty of ummah (community/nation). ${ }^{33}$

This chapter explores and analyzes Ghannouchi’s theory of sovereignty. It demonstrates how Ghannouchi, drawing from Islamic ideas and Islam’s political practices, argues for the sovereignty of the ummah. The chapter determines his departure from and overlaps with the 
theoretical underpinnings of divine and popular sovereignty. It also identifies some limitations and practical challenges of Ghannouchi’s interpretations of sovereignty in Islam.

The chapter starts with the historical exploration of the making of Ghannouchi's theory. It shows that he argues for the position that Islam as a religion is separated from politics. It also maintains that Ghannouchi belongs to the early scholars who believe that by viceregency, God gives the human being the agency to manage temporal affairs. Then, in the next section, the chapter describes and analyzes the theoretical underpinnings of Ghannouchi's sovereignty of ummah. It attempts to explore who is the ultimate sovereign in his arguments and based on what contract ummah engages with itself and the rulers. It further intends to examine the place of shari' $a$ in Ghannouchi's thought, and how rulers get ummah's legitimacy to rule over temporal affairs. Next, the chapter explains the limitations and practical challenges of his theory. Finally, in the concluding section, it summarizes Ghannouchi's arguments on sovereignty.

\section{Ghannouchi's Thought in Historical Debates}

Ghannouchi's thought on sovereignty carries the legacy of two significant debates in the Islamist political thought: the debate on separability/inseparability of politics from religion, and the debate on the vice-regency in Islam. Unlike the Western political thought where it is accepted that religion is separated from politics, ${ }^{34}$ the dominant understanding in Islam is that it is impossible to separate Islam from politics. It is because of the distinctive nature of Islam as a religion, its historical evolution, its "exceptional" attributes, its early rapid expansions and so forth. ${ }^{35}$ The other argument in this debate, but relatively marginalized, is that religion and politics are two separate entities in Islam. For some scholars, the separation occurred after the death of Prophet Mohammad, while for others, Islam's separation from politics ultimately happened with the end of four rightly-guided Caliphs' governance. Ghannouchi belongs to the 
second school with a claim that Islam is separated from politics. For Ghannouchi, politics, and Islam were separated from the very beginning of Islam, during the time of Prophet Mohammad. However, Ghannouchi argues that this cannot be claimed in the sense that the separation happened in the Western political tradition. Ghannouchi, rather, identifies Islam’s separation from politics as a distinct phenomenon (Ghannouchi, 2013).

Ghannouchi calls it distinction ${ }^{36}$ because he argues that Mohammad used to clarify which of his statements were revelations and which were his political commentaries. In Ghannouchi's language: "If it were a revelation, he [Mohamad] would say so, and if it were political, he would say it is opinion or advice, and they were then free to disagree with him” (Ghannouchi, 2013, p. 166). Ghannouchi further clarifies the "Prophet’s statuses” citing from Sheikh Taher Bin Ashour: When he had the status of Prophet, people owed him total receptivity and obedience, and when he had the status of army and political leader, he could decide on a position for the army yet a companion could come and tell him, by God, the other position is better, and he would actually change his mind a degree with that companion (Ghannouchi, 2013, p. 166-67).

With a historical exploration of Mohammad's time, Ghannouchi contends that he was at the same time a religious imam and a political imam. Mohammad not only led the community in the mosque but, at the same time, reconciled disputes among people, led his army at war, signed treaties, and conducted other political affairs. After arriving in Medina, ${ }^{37}$ Mohammad firstly built a mosque, and secondly drafted a constitution by the name of Al-Sahifa (Madina Charter) (Ghannouchi, 2013). The constitution gave birth to a community/nation accommodating people from different clans and faiths. Mohammad identified them as a political, rather than a religious ummah (Ghannouchi 2013). Ghannouchi claims that Mohammad made a distinction between his religious and political roles in the community. The religious purpose is to provide the faithful with answers on major existential issues such as their origin, fate, the region they were born. It 
offers them a value system and a set of principles based on those the community is organized. On the other hand, Ghannouchi argues that the political role is "to dictate agricultural, industrial or even governance mechanisms, or manner of managing state affairs; these involve particular technologies, and people’s minds are well equipped to learn from experience what best to do” (Ghannouchi, 2013, p. 167). Ghannouchi's political objective is different from the political imagination of Western liberal tradition. He seems to be less concerned regarding the politics of conflict management and materialistic worldly gains. Ghannouchi, instead, stresses the ethical side of politics. He argues that the objective of politics is to improve human welfare. In Muslim societies, the fundamental aim is to transform people into better Muslims. The purpose of political institutions is to harmonize certain kind of moral unity of ummah that gives them space to decide welfare policies through a dialectic process of text, tradition, and consultations (March, 2018a).

The second historical debate that Ghannouchi carries a legacy is the vice-regency debate in Islam. He declares that ummah (community/people) is the vice-regent of God on earth, and it is people's will that offers the political legitimacy to the rulers. It is one of the radical and unexplored arguments among diverse interpretations of khalifate Allah (vice-regency of God). There has been a historical debate if khalifate Allah refers to the rulers, the decedents of Adam or entire human generations followed him. The dominant argument was the former. The early Islamic scholars from Al-Tarabi to Al- Razi to Al- Qurtubi, among others advocated this interpretation of vice-regency (Idris, 1990). In this interpretation, the Caliph draws his authority directly from God. The Caliph is assumed to have the same position as the Prophet to the community. He is, therefore, "expected to govern their affairs and is entitled to receive their 
unconditional obedience while exercising absolute sovereignty over them” (Razek 2013, p. 27). None is entitled to share authority with the Caliph.

Against this argument, Razek declares that neither the Holy Quran nor the tradition of the Prophet refers explicitly to the nature of Caliphate. The rulership throughout Islamic history, Razek maintains, exploited the concept of the Caliphate with a religious reference. For Razek (2013, p. 52), Caliphate could be "a necessary condition for the practice of religion and the realization of the general good of the Muslim community." Choosing a leadership and arranging governance that would ensure general good for the community becomes a temporal affair. According to Razek, it is purely a secular enterprise. Alajmi (2011), explains this position arguing that any person capable of cultivating the earth or rule over another person could be "God's caliph.” Whereas in these arguments, the spiritual part is somewhat excluded, in Ghannouchi's contention on the ummah as the vice-regent of God, the spiritual reference remains significant. He argues that people do not possess their inherent rationality, but perform temporal affairs based on rationality they receive from God. This vice-regency thesis is a central point to Ghannouchi's argument on sovereignty. In the following section, I will discuss it in detail.

\section{The Sovereignty of ummah in Ghannouchi's Thought}

Ghannouchi's thought on sovereignty is informed by his Islamic conception of politics

that is shaped by two basic principles of his thought: his belief in the metaphysical account of the totality of existence, and his subscription to the siyasa shariiyya of Islam. Firstly, Ghannouchi believes, "God is more knowledgeable than all of His creatures and the highest legislator and commander, and that man has been distinguished from the rest of God's creatures by his designation as God's deputy, through which he has been entrusted with reason, will, freedom, responsibility and the divinely ordered path for his life” (Ghannouchi, 1993, p. 37). This totality 
of God does not preclude the rational interpretations of the divinely inspired laws and norms. Ghannouchi "conceives of Islamic rationalism as the dualism of reason and revelation" (Tamimi, 2001, p. 31). In his thought both revelation and reason coexist. Both combinedly work as the source of knowledge. He assumes a harmony between the two sources arguing that the acceptance of revelation as an essential principle where reason must be employed to interpret revealed texts. For him, any inconsistency between the reason and revelation is to be unexpected and erroneous that is to be disregarded (Tamimi, 2001). According to Ghannouchi, Islamic rationality complies with the Western philosophies while recognizing the existence of objective reality but differs when “it rejects the principles of reason’s independence of knowledge as a whole" (Tamimi, 2001, p. 31). The reason is acceptable unless it contradicts the very foundation of divine law.

Secondly, Ghannouchi is heavily influenced by the siyasa shariiyya tradition of Islamic law and governance. Siyasa is one of the significant but less known branches of pre-modern shari'a jurisprudence. Islamic jurisprudence historically has two branches: fiqh, rules explored from scriptures by the Islamic legal scholars that pronounce an appropriate conduct for the community and siyasa, laws those are formulated by the worldly rulers for public good based on experiences and practices of governance. Siyasa laws, unlike fiqh, are constructed by Muslim rulers by their philosophical understanding of government and thoughts about their subjects. Quraishi-Landes (2015) argues that siyasa laws are generally derived from the practices of governance, laws related to rulership that cover issues, such as security, taxes, public safety, regulating markets. Siyasa laws cover things that are essential for the maintenance of an ordered community, but revealed texts contain little references. There have been tensions between the fiqh and siyasa laws where it is feared that the later undermine the authority of the former on the 
one hand and goes beyond the limits of revelation on the other. Quraishi-Landes, however, argues that fiqh scholars had to accept the necessity of siyasa laws because fiqh laws do not offer all references to everyday governance. Quraishi-Landes further maintains that siyasa cannot be determined as secular laws as the experiences and practices of Muslim rulers were very different from that of the Western rulers. Unlike the Western rulers, Muslim rulers governed their subjects with an Islamic objective in mind and an Islamic identity to maintain, with reference to the revealed texts.

These two theses emerged from Ghannouchi's radical argument that the human being is God's vicegerent on earth (Ghannouchi, 1993, p. 97). He contends that man's responsibility on earth is to establish social justice according to God's revelation and they accomplish that freely with the reason, will, and freedom they achieve from God. From the vice-regency theory, Ghannouchi derives the two sources of authority in the Islamic state: shari'a (the text) and shura (consultation) (Ghannouchi, 1993, P. 322). The former represents the authority of God while the latter epitomizes the authority of humans what Ghannouchi refers to as the balance between the state of God and the people (Ghannouchi, 1993, p. 148). It is to "realize shari'a, to instantiate the absolute in the course of history, and to connect the divine with the human” (Ghannouchi, 1993, p. 104). When Ghannouchi attempts to theorize sovereignty in Islamist politics, he seeks to reconcile both divine and popular ideas of sovereignty where he found a resonance of siyasa shariiyya tradition of Islam. Based on this tradition, Ghannouchi "begins with the premise that there is no designed representative of God or man; mankind's collective authority cannot be merely usurped on epistemic grounds. Actual, practical, political authority originates entirely with the people, which holds this authority on loan from God” (March, 2015a, p. 19). March argues that Ghannouchi does not denote the idea of popular sovereignty from the theological 
point of view to have a distinction between the Sunni and Shi'ite one, or as a way to have rulers' legitimacy through the rituals of bay'a (the oath of loyalty through which the ruler comes to be legitimate). For him, March articulates, a contract of agency between the people and rulers legitimizes all political authority. Does this contract involve the delegation of the responsibility to enforce the shari'a? Ghannouchi argues that the executive authority is completely civil, and his point in this conception of "shared divine and popular sovereignty" is "Text and Consultation (shura), which he equates with the shari'a of God and consultation amongst the people, reason, and revelation, constraint, and freedom” (March, 2015a, p. 19).

In this regard, the question arises if Ghannouchi authorizes the traditional Islamic jurists or ulama to participate in the process of consultation. Ulama are the scholars who interpret laws and represent the people to constrain the excessive power of the rulers. Ghannouchi like the proponents of divine sovereignty Mawdudi and Qutb, discards the textual authority of traditional ulama. He believes that texts are open and subject to reinterpretations in accordance with time and contexts. Ummah, as a whole, is authorized to interpret revealed texts. He replaces the jurists place with ummah with the embodiment of democratic institutions and practices to the Islamic political thought. Ghannouchi "finds the precedents of democratic institutions in Quranic and early Islamic practices of consultation (shura), popular ratification of rulers (bay'a), communal consensus about religious practices and points of law (ijma), and the collective scope of the interjection to command the right and forbid the wrong” (March, 2013, P. 309). The base of these practices is shari'a, but traditional jurists are not the only authority of their interpretation as there is no theocratic authority in Islam. Unlike the medieval practice of Christianity, Ghannouchi declares, because of the absence of any central religious authority, "no one can 
claim to have the sole right to interpret religious texts or to speak in the name of the Heavens or to be God's shadow on earth” (Tamimi, 2001, p. 99).

The authority of shari'a, however, remains supreme, at least normatively, in Ghannouchi's thought. This unified divine authority that ummah (community) gets from God is the ultimate sovereign power in political affairs. Ghannouchi contends that the "supreme, irresistible, absolute neutrality and uncontrolled authority" of a modern nation-state in the western political thought is rather ambiguous (Tamimi, 2001, p. 99). In this respect, the parliament or a political body that emerges as the sovereign entity with the mandate of people, might monopolize the power and abuse it. It leads as Ghannouchi described, to the "catastrophic decisions." It is, for him, the consequences of "granting absolute powers to legislators who in turn assume the role of God” (Tamimi, 2001, p. 99). That scope of monopolizing power either by the political body or legislators is nearly impossible in Islamic democracy where shari'a remains supreme, sanctified, and entirely neutral. To be objective, and just for the shareholders of an Islamic state is not only a professional duty but also a religious responsibility.

Ghannouchi’s fundamental contribution to the theory of sovereignty in Islamist political thought is his doctrine of man's viceregency of God. While the earlier Islamists, by the viceregency of God, referred to rulers or a political body, Ghannouchi moved it to ummah. Based on his metaphysical account of the totality of God, and articulation of the Quranic verse (Quran, 2:30) in which God refers to mankind as a whole as his deputy or viceregent, he designates people as God's deputy. The belief is that God has created humans with an honor and gifted them with such a mind and power that all other creatures are created for their service. As a viceregent of God, a human has certain rights and responsibilities towards other humans and creatures. 
People perform these responsibilities in various capacities engaging in a social contract that culminates to the formation of a government. Ghannouchi's social contract of a legitimate government in Muslim majority countries complies neither with the social contract theories of the Western political thought nor with the arguments of the advocates of divine sovereignty in Islam. It also rejects the contract of the late medieval Islamic political thought that offers the legitimacy of the Saudi monarchy where it is argued that a ruler gets legitimacy and achieves the "legal status of the imam in all things once he gains power by force over a city or country" (Vogel, 2000, p. 210). In the Western tradition, the contract is exclusively between rulers and ruled where the latter have the absolute authority to elect or dismiss the former. People are completely free to exercise their individual autonomous agency. They are not bound to any spiritual entity, at least in the Rousseauian social contract, where individual agency is "neither represented nor alienated.” It does not depend on God's will; it is also not delegated to rulers absolutely. Instead, as Rousseau argues, sovereignty emerges from people, and it stays there (Rousseau, 1997). In contrast, in Ghannouchi's thought it could be inferred that, sort of Lockean way, individuals are engaged with two contracts simultaneously. They are, on the one hand, in an inalienable contract with God with the complete submission of authority to Him and, on the other hand, they, borrowing agency from God, are in another autonomous contract with rulers. In this dual contract, it is debatable, to what extent, individual free agency is recognized.

Ghannouchi's dealing with this duality should be examined on two grounds. First, how he places the role of shari'a in the contract, and second, how Ghannouchi perceives the relationship between the rulers and the ruled in the governance of Muslim majority countries. He does not deny that the contract between God and individuals is based on the shari'a of God and that informs the contract between rulers and individuals. However, Ghannouchi argues that 
although the faith part of the contract is inalienable, the political part of it (broadly other aspects of life in the world) could be reinterpreted in the context of the changing time and context. In this regard, he departs from the divine sovereignty thesis which argues that in Islam faith and politics are indivisible. Unlike Mawdudi and Qutb, his thesis is that politics and governance are civil issues. ${ }^{38}$ His conception of shari'a also radically differs from the Mawdudian and Qutubian interpretations. These scholars considered shari'a as codified laws that would be executed by the state from above to establish an Islamic state. For Ghannouchi, however, shari'a is a moral guide that would inform individuals with faith-inspired morality, and ultimately would be instrumental in the social Islamization from the bottom. He argues that legislators should neither be guided by the ulama nor by Ministry of Religious Affairs in the process of enacting laws, rather their guidance should be Islamic values embedded within them (Ghannouchi, 2013). Man, thus, becomes as miniature Gods in Lockean terms as Shapiro comments where every individual inherently carries the moral values of God and acts on them (Shapiro, 2003). It, however, should not be interpreted that Ghannouchi undermines the authority of shari'a. Ghannouchi, indeed, argues that Muslims live in a dangerous time not because "they are deviating from the shari' a, but because they are resisting the authority of shari'a; they are less and less taking shari'a to be authoritative over them” (Sadek, 2012, p. 50).

It would nevertheless be erroneous to assume that Ghannouchi wants shari'a authority to replace positive law. He, instead, argues that shari'a should be interpreted in the modern circumstances and its ethos should freely mediate into the individual's everyday personal and social affairs. In his words, in Islamic societies "shari'a must be adapted to the modern contexts, one according to which man is independent of his creator" (Ghannouchi, 1993, p. 100). For him, historically no single codified shari'a law governed the Islamic dynasties or empires. Islam did 
influence laws and state behaviors, but those are in the form of Islamic values enacted by people as they understood texts. He argues: "Countries have remained Islamic not because their laws, behavior, and measures are based on the revelations, but thanks to human interpretations that are either supported or contradicted by other interpretations” (Ghannouchi, 2013, p. 167). He emphasizes that ensuring social justice that is attainable by following God's revelation. He articulates: "all Muslims must continue the effort and cooperate to fulfill Allah's commandment and establish justice on earth” (Ghannouchi, 2006, p. 167). As his focus remains on individual and societal Islamization, in the Tunisian constitution formulated under the tutelage of Ghannouchi's party Ennahda, did not mention shari'a as the source of positive law. The constitution eliminates the word shari'a; it is mentioned that Islamic teachings would guide the nation.

However, Ghannouchi seems to be ambivalent locating the precise place for shari'a. When he writes, in an Islamic government, "supreme legislative authority is for the shari'a, that is the revealed law of Islam, that transcends all laws," the location of shari'a whether to see merely as a moral guide or place in a position to dictate positive laws becomes confusing (Ghannouchi, 2006, p. 272). The ambiguity is further augmented with his overarching emphasis on shari'a by articulating the Quranic verses: “Judge between them by what Allah has revealed and follow not their vain desires" (Quran, 5:49), and “Those who do not judge by what Allah has revealed, they are unbelievers” (Quran, 5:44). In Ghannouchi’s articulation, it also seems that shari'a depends on an individual's free exercise of agency in the social contract. He comments: 'In Islam, the contract of bay'a does not found the state, because the text is already there, and Muslims are not free as long as they remain Muslims to apply the rules of shari'a or to invalidate them” (Ghannouchi, 1993, p. 146). Sadek argues that in Ghannouchi's interpretations of shari'a 
people are not absolutely free to exercise their agency. It is not the fact that individuals are not allowed for self-reasoning. Rather, Sadek maintains that an individual's ethical reasoning is dictated and structured by the authoritarian reasoning determined by shari'a (Sadek, 2012). He further clarifies: "By accepting the authority of al-Nass [shari'a], one is thus limiting the objects of her ethical reasoning and is no more in a position to question the validity of al-Nass itself. Being so constrained is sufficient to say that the ethical autonomy of the agent is undermined" (Sadek, 2012, p. 116-117).

This debate on agency leads us to the second point of Ghannouchi's duality in social contract. In Ghannouchi's thought, the rulers and ruled relation in Islamic societies is developed based on a contract that is on the one hand overlapping, and on the other hand, deviating from the Western political thought. Ghannouchi claims that in Islamic societies under God's omnipresence, there is no hierarchy of relations among people. In a Lockean way, he argues that God established a harmony of the relationships among people as He did it in the cosmos. However, unlike Hobbesian state of nature where individuals are in a state of war, Ghannouchi akin to his predecessors Mawdudi and Qutb, argues that people in Muslim societies are in an inherent relationship of brotherhood informed by faith under the rubric of the universal ummah, the community of the faithful. ${ }^{39}$ The basis of this brotherhood is a faith inspired morality (Ghannouchi, 2013; 1993). However, the insecurity and the inevitability of conflict, like any other societies, lead the Muslim societies to establish a social contract among people. In the contract, some are assigned with executive power to govern. Therefore, it is not only the extreme Hobbesian fear that leads the individuals to engage in a contract, but both existential insecurity and aspiration to establish Islamic societies contribute to the formation of the contract. It would be irrational to state that individuals only want peace and security in the community, but they 
consider it as a part of their religious obligation. For individuals in a community, it is a divine responsibility of developing a peaceful community.

Individuals submit their will voluntarily to the rulership and seek security and justice from them. This will is not inherent to them; rather Ghannouchi contends, Muslims borrow the will from God. Getting agency from God, individuals are free to use that rationally. This freedom is the consequence of human's God-given responsibility and agency (Ghannouchi, 1993, p. 144). For him, "freedom of faith is personal freedom far from any compulsion and this freedom includes the right to embrace or leave religion” (Ghannouchi, 2018, p. 22). Through the governing mechanism (shura), this agency, then, leads to a kind of contract exists in the Western political thought where people rationally choose, to whom and to what extent, to submit their will. This contract is not divine or charismatic self assertation. Rulers in Islamic governance are agents of people bestowed with very specific functions and the source of their authority is always ummah, the people who assigned them the tasks. The terms of the contract could be summarized, as March (2015a) points out into three points: to apply shari'a; to make public policies only with the welfare (al-masaliah) of the ummah in mind; and, to strictly maintain the obligation to consult (shura) the ummah. Under the contract, after the submission of will, individuals neither become “sleeping sovereign” in Hobbesian sense nor transform into a passive-powerlessness entity as they become in Bodinian contract. Instead, it could be inferred from the Ghannouchi's writings that, sort of Rousseauian and Lockean way, individuals’ agency remains in them. They do not waive their right to dismiss the rulership anytime that appears illegitimate, despotic or corrupted to them. For Ghannouchi: "there is no absolute delegation of authority through the contract of the agency; there can be partial delegation, and the forms and conditions of such offices can be multiplied” (Ghannouchi, 1993, p. 170). He further comments, "the ummah does 
not retire once the Hukumah (government/the group of people who are assigned for governance) is appointed; the hukumah only takes charge of tasks that individuals and groups are incapable of carrying out” (Tamimi, 2001, p. 100). The difference between the Rousseauian and Lockean agency from Ghannouchi's is that in the case of the former, the agency comes from nature while in the latter, the source of agency is personal faith. Ghannouchi calls it the God-dependent view of the human being. For him, this is the core distinguishing feature between the Western secular perspective and Islamic perspective of looking at the world. In his words: "that [human being] is always in need of the creator and is incapable of separating from the creator without jeopardizing his humanity” (Sadek, 2012, p. 47).

In Ghannouchi’s thought although faith’s moral inspiration is integral, the contract between the rulers and ruled is entirely civil. Rulers do not enjoy God's divine authority like the divine power of kings claimed in the medieval Christianity dominated rulership. They are bound to God's authority in a kind of Lockean voluntary God where they are accountable to Him particularly matters related to faith. But they are not allowed to override God's laws. The difference in the Ghannouchian reference to God is that, unlike Lockean, in Islamic case texts exist and rulers cannot act against those. However, they have the authority to interpret texts differently in modern contexts. Rulers neither enjoy the absolute authority to rule as one would see in the Bodinian and Hobbesian contract, nor they remain above laws those they formulate. Rather, in Ghannouchian contract, rulers are like any other individual and subject to laws they make. They are not separated from the mass; remain one of them in the process of governance. In Ghannouchi’s words, both rulers and ruled are subject to the same laws (Sadek, 2012). The prime responsibility of the rulership is to ensure human welfare. 
This establishment of human welfare is a completely temporal responsibility performed by a political authority in Ghannouchi's democratic civil state. ${ }^{40}$ People must ensure that without being dependent on any other entity. This argument reflects in the founding declaration of his party Ennahda:

the people's reclamation of their legitimate right to self-determination far from any internal or external tutelage...rejection of violence as a method of change...consultation as the means of deciding on matters of thought, culture, and politics. Rejection of authoritarianism and monopoly of power... and affirming the right of the people to exercise freedom of expression, assembly, and all legitimate rights, and to cooperate with all national forces to achieve this (Ghannouchi, 2018, p. 20-21).

He envisions state as a democratic institution drawing its legitimacy from the people’s free will. The establishment of it is a matter of consensus among all political trends under a framework where "sovereignty belongs to the people through peaceful rotation of power via free elections, and on the principle of the separation of powers and balance between them" (Ghannouchi, 2018, p. 21). Ghannouchi argues for an Islamic democracy which, unlike Western democracy, is bound to a set of divine guidelines. It is not in the form of a set of coded laws, rather based on the philosophy that "Islam is God's final word to humanity, and a comprehensive global message of mercy and justice to mankind” (Tamimi, 2001, p. 91). Shari'a would be a broad guideline of serving human welfare. Ghannouchi benefited from and relied on AshShatibi's theory of al-masaliah arguing that shari'a should be interpreted in a way that ensures maximum human welfare. The fundamental idea is that the objective of divine revelation is the improvement and attainment of human interest, justice and wellbeing in the life and the hereafter. He cites Quranic verse: "We sent aforetime our Messenger with clear sights and sent down with them the Book and the Balance (of right and wrong), that men may stand forth in justice” (Quran, 57:25). Al-masaliah is "used as a guiding principle in the procedure of deriving laws by analogy (qiyas) when applying a text to a situation that is not covered by Shari'a" 
(Sadek, 2012, P. 108). It is also used to defy scriptural rulings and verifying the validity of already established laws. ${ }^{41} \mathrm{Al}$-masaliah "presents jurists with a framework to tackle the problem, inherent in a legal system that is based on a finite text, of bringing to bear the limited material foundation of the law (i.e., Qur'an and hadith) on everyday life in an ever-changing environment” (Opwis, 2005, p. 183).

Ghannouchi accepts Al-Shatibi’s categorization of Al-masaliah as “essential requirements" within which all the elements of religion are to be incorporated, and "all new problems in the lives not only of Muslims but of all humanity, can find proper solutions that guarantee the fulfilment of their requirements” (Sadek, 2014, p. 160). Sadek argues that Ghannouchi employs it to adapt God's law and accommodate for the needs of Muslims. Ghannouchi illustrates examples how and the extent to which shari'a was historically interpreted for the human interests. It draws those from the general practices in the events of Prophet's lifetime, Negus, and Umar ibn Abdul Aziz's rulership ${ }^{42}$ while they had to share power with nonIslamic governments in many capacities (Ghannouchi, 2006, p. 274-275).

The argument for civil, autonomous political authority in Islam and its practice is not new. Historically, the Kings and Caliphs' political authority was somehow separated from the religious authority, argues Ghannouchi and the authority of them was derived from the people (Ghannouchi, 1993, p. 149). Early Caliphs sincerely sought ummah's bay'a for their legitimate rule and declared that their authority was dependent on their unvacillating commitment to rule within the limits of God's laws. It is not the superficial, ex post facto tradition of the bay'a displayed in modern Islamic monarchy practiced in Saudi Arabia (March 2015a). Therefore, Ghannouchi argues that historically it is established that ummah is the de facto source of all political authorities and powers and remains the ultimate sovereign within the statutory 
framework (Shari'a). In his words: ummah is "the possessor of supreme sovereignty in matters of governance via its election, supervision, accountability, cooperation with and removal of the ruler” (Ghannouchi, 1993, p. 71). Political authority belongs to the Ummah, and it must be practiced with a mechanism of shura (consultation). The establishment of a government based on Islamic norms and ethos, therefore, for Ghannouchi is not the sole responsibility of rulers. It is "the duty of the believers to spare no effort in establishing it” (Ghannouchi, 2006, p. 273). The community should not embrace passivism and isolation but should be stakeholders of establishing governance serving the interests of the public such as the protection of faith, soul, wealth, and prevention of evils.

However, Ghannouchi, although, argues for a civil state, he is not an advocate of an entirely secular government. He argues that if an Islamic government seems impossible to be established soon, the community should not abandon their attempt to accomplish it. For him, the struggle for Islamic government has a significance because it is not only a temporal duty of the individuals to establish it but is a part of their religiosity. Ghannouchi writes: "it is the religious duty of the Muslims, as individuals and as communities, to contribute to the efforts to establish such a system [Islamic democratic government]” (Ghannouchi, 2006, p. 273). Quoting Ibn Khaldoun, he maintains that if Muslims fail to establish an Islamic government, they at least should strive for a government of rationale. He, however, did not clarify what he meant by the rational government. It reveals from his writings that upon Muslims' failure of establishing a government of Islamic values to be implemented, they at least should attempt to establish a just government. For him, “a just government, even if not Islamic, is considered very close to the Islamic one, because justice is the most important feature of an Islamic government, and it has been said that justice is the law of Allah” (Ghannouchi, 2006, p. 275). 
Justice would largely be guaranteed, Ghannouchi argues, if the genuine utilization of shura becomes possible. It offers political legitimacy to the rulership. Shura presents the best opportunity for the ummah to exercise their collective autonomy. He calls it "the spinal cord of the ummah's authority in establishing a political rule by participation, co-operation, and responsibility” (Ghannouchi 1993, p. 109). With voluntary participation and cooperation in the social and political debates of the public sphere through public reasoning, ummah brings better solutions for the contemporary crisis of the community. Since Islam has no specified procedural mechanisms of shura that leads Ghannouchi to argue, "any allowed path that can indicate or show who gets the trust of the ummah is acceptable, and there is no doubt that elections in these times are among the acceptable ways that we can use under the condition that there be no tricks and deceptive means” (Ghannouchi 1993, p. 125). For Ghannouchi, shura is not only a process of collective decision making, but it is a way of acknowledging an individual's independent thinking, a way of safeguarding individuals from the tyranny of authority. It is also a way of mediating difference, developing personal relations, and creating common grounds for ummah on political and social issues. In Ghannouchi’s words: "Shura is not merely a style of managing political matters...but is a way of life that springs from the general viceregency of humans, the primacy of the collective over the individual and considering the individual to be weak on his own but strong with his brother, and mistaken on his own but enlightened towards his best with his brother” (Ghannouchi 1993, p. 190-192). The nation's collective representation in the mechanisms of shura speaks in the language of the divine will (Ghannouchi 2013). Ghannouchi contends, "the only representation of the divine will is inherent in the nation itself, which it expresses through advocacy rather than by monopolizing of a certain imam, political party or state” (Ghannouchi 2013, p. 168). From the legislative perspective, in the practice of shura, the 
authority of textual interpretations is not to be dominated by a single group or institution. As vice-regent of God, Ghannouchi claims, "the ummah collectively and unitedly deputizes for God in implementing His law, shari'a, and is therefore held responsible by Him and is accountable to Him” (Tamimi 2001, p. 100).

He further argues that ummah ideally not only holds the power to form a government but also to direct and dismiss it. The limited power delegated to the rulership, for Ghannouchi, is enough to carry out the set of tasks assigned to them. Ummah works as a balancing factor in the governance that stops the rulers to become despotic. He claims that the political authority in the process of shura is neither theocratic nor totalitarian. It is not theocratic because God's codified laws are not directly implemented, and not totalitarian because ummah does not submit all of their authority to the rulers on the one hand, and the ultimate sovereignty, within the supreme jurisdiction of shari'a, remains as the indivisible part of ummah. The shura functions as the medium of restricting the government both from the ground of temporal, social contract and religious-moral obligation embodied in shari'a. Ghannouchi notes that while God is the source of legislation, the ummah through its public practices of shura, participates in the divine will. The process of shura also restricts and limits the texts of revelation for the determination of general principles for organizing human relations. It is a practice that Ghannouchi equates with the idea of universal communal consensus (Ijma) as a source of divine law alongside revealed texts (March 2015a). This leads Ghannouchi to declare that concerning the political matters "the ummah is guided by God and acquires from His light protection against collective errors” (Ghannouchi 1993, p. 119).

God remains the ultimate sovereign in Ghannouchi's political thought. Ghannouchi's contribution, however, lies in the point that he articulates the viceregency of ummah more 
convincingly and argues for people’s autonomous agency in temporal-political affairs. While Mawdudi and Qutb denote ummah's viceregency as merely God's representation on earth and rejects any claim for their own agency, Ghannouchi maintains that it is ummah's autonomous agency and religious responsibility that would guarantee human welfare. It would be done through the reinterpretation of God's revealed laws. This coexistence of divine will and human will in Ghannouchi's thought could be a path of a departure from the paradox of Islamist sovereignty. It, however, would be misleading to infer that Ghannouchi argues for “multiple claimants” of the sovereign as one interpretation of Lockean sovereignty would claim (Scott, 2000). His contention rather is that human will is acknowledged under the larger realm of God's sovereignty. He maintains that political authority lies in the people and they enjoy all rights to decide on political matters. It is a complete break away from his predecessors of Mawdudi and Qutb’s thoughts whose fundamental argument is that both religious and political authority belong to God. The separation between the two, for them, not only threatens the political stability in an Islamic society but also jeopardizes the individual religious integrity. The separation of politics from faith drives Muslims, as Qutb determines, to Jahiliya.

Ghannouchi’s sovereignty that apparently shifts towards the direction of popular sovereignty is a radical break from the divine sovereignty thesis in Islamist political thought. It argues for mass participation in reinterpreting shari'a and making collective decisions. Unlike, the divine sovereignty thesis, Ghannouchi's political theory held that shari'a as a moral principle would guide the community. It will not work as positive laws. The community would be selfgoverning with a moral purpose and religious commitment where morality, will, and virtue would work together to accomplish a common human goal. March (2018b) correctly comments that Ghannouchi argues for a deliberative shari'a that emerges out of institutions, public opinion 
and the participation of people in order to figure out representation of a particular time and place with a dialectics of texts, traditions, and contemporary moments. March, however, while highly appreciative of Ghannouchi's theory on sovereignty, calls it hybrid sovereignty because of his duality between God's ultimate sovereignty and ummah’s independent agency (March 2015a). To some extent, March's argument, with other scholars such as Khan (2005) and Sherwani (1942) assumes that this Islamists' duality could be replaced with popular sovereignty for Islam's perfect compatibility to liberal democracy. It becomes more clear when March argues for the "invention" of popular sovereignty in Islam. ${ }^{43}$ In this regard, March falls in the same category of scholars such as John Esposito, Muktader Khan, Khaled El Fadl, Nader Hashmi who argue that Islam is compatible with Western liberal democracy. Therefore, it seems that Islam bears the burden of proving its compatibility and it should accommodate the intricacies of liberal democracy. Mahmood (2004) rightly criticizes this take of the scholars arguing that Islam must scrutinize its own traditions and texts where the solution to the crisis it faces could be found instead of looking for compatibility in a hierarchical comparison with liberal democracy. For her liberal democracy is full of paradoxes and inconsistencies those should be critically scrutinized, and alternative visions of democracy, e.i. from Islamic tradition, should be acknowledged.

I, however, would neither identify Ghannouchi's sovereignty as hybrid nor would attempt to "invent" popular sovereignty in his thought. Throughout the chapter, I strived to locate Ghannouchi's sovereignty in its own merit. I, however, had to use vocabularies and concepts of the Western political thought and write in a comparative fashion since Islamist political thought lacks such articulations and debates. I, nevertheless, subscribe to Ghannouchi's contention that the very distinctive nature of religion, history, and philosophy of Islam, makes its articulation of sovereignty distinctive. The fundamental exceptions include the absence of central religious 
authority and the presence of supreme revealed texts. Consequently, in Islam, the ultimate sovereignty did not shift from God to the king, and then from king to people as it happened in the Western political thought. These exceptions, more specifically, the impossibility of excluding God's reference, as Ghannouchi shows, do not preclude Muslims to embrace the ethos of liberal democracy. For Ghannouchi democracy is not only a procedural-political process of conflict management; instead, borrowing from Algerian scholar Malek Bennabi, he argues that democracy is an educational enterprise for the whole community (Tamimi, 2001). It is a wideranging program that incorporates psychological, ethical and social aspects that have Islamic roots revealed in Quran and Hadith and practiced in the Islamic tradition of politics. Ghannouchi, thus, argues that it is entirely the human enterprise to trace out those both from the texts and practices and contextualize in current moments. In this human endeavor, they do not reject God's sovereignty but honor it. El-Fadl (2004) argues that when human beings in Islamic societies tends to establish God's justice on earth, they are not in the position of the denial of God's sovereignty, rather they honor it. They also honor it while dealing with political affairs by safeguarding the moral values that reflect the attributes of the divine.

Nevertheless, this shift from God's absolute authority to recognizing ummah’s free agency at least in temporal matters is not as simple and straightforward as Ghannouchi argues. Similarly, authorizing individuals for reinterpreting shari' $a$ and reducing it into the community's moral principles while curtailing the ulama's traditional scriptural authority are neither clearly articulated nor seems to be readily accepted among scholars. For some, Ghannouchi's thought is apologetic while for others, his thought is infeasible-directly contradictory to the fundamental ethos of Islamic laws and polity (Donker, 2013 ). Ghannouchi assumes that individuals are educated and enlightened enough to interpret scriptures. Islamic jurisprudence is a science that, 
however, needs a rigorous methodological training, and vast historical knowledge, along with the fundamental ability and training of decoding texts. This debate is not new and even could be found within the tradition of the ulama. For instance, the Deobandi ulama in South Asia accuses the Ahl-i Hadis ulama on the ground that Ahl-i Hadis's direct approach to interpreting original texts, rejecting the medieval Islamic jurisprudence established by ulama, alienates the masses. ${ }^{44}$ They argue that this elite dominated approach creates a hegemony of interpretation over the masses as ordinary people seldom possess command over texts and methods. The relevant challenge would be while the individual would start interpreting shari'a, the heterogeneity of interpretations that might not comply with the democratic-normative imagination that Ghannouchi demonstrates. How is to reconcile those heterogeneities in the absence of any central authority? Should the state intervene on this? That is also not possible in Ghannouchian thought as he argues that religiosity is an individual issue where state intervention is not welcomed. Furthermore, the ulama's traditional authority on Islamic affairs in the modern nation-states although curtailed with the introduction of codified positive law, their authority on public Islam remained nearly undiminished (Zaman, 2002). Zaman argues that ulama's authority over textual interpretations and public Islam has significant political implications. It is also revealed that their heterogeneous interpretations do not necessarily comply with liberal democratic values and norms. It, therefore, remains a crucial factor, how to find a way out to reconcile heterogeneity of textual interpretations so that those inform common democratic values in Islamic societies.

\section{Conclusion}

In this chapter, I have shown that Ghannouchi’s theory of sovereignty carries two historical debates in Islamist political thought. The first one is a perennial debate if Islam and 
politics are separable and the second debate is on the meaning of viceregency in Islam. In the first debate, Ghannouchi argues that religion and politics have been two separate entities in Islam from the time of Prophet Mohammad. With Mohammad's statements and practices of later Islamic dynasties and empires, Ghannouchi's argument is that theological and political matters in Islam have always been separated. In the second, viceregency, debate, Ghannouchi unambiguously argues for the viceregency of people. These two takes on historical debates in Islam significantly inform his theory of sovereignty.

I also argued in line with March’s (2015a) argument that two fundamental principles of Ghannouchi's thought shape his theory of the sovereignty of ummah. The first is his belief in the metaphysical account of God, and the second is his attempt to reinterpret contemporary Islamist politics based on the siyasa shariiya tradition of Islam. According to the former, he argues that God is the ultimate sovereign as the highest commander, legislator over the whole universe. According to the latter, he, however, maintains that the temporal-political affairs of ummah are managed by the people with the mechanism of consultation (Shura) based on texts (Shari'a) and human reasoning gifted by God. This governance mechanism, according to Ghannouchi, is arranged based on two contracts. One is an individual's contract with their God where they unquestionably submit their complete authority to Him. Another is a social contract among people that comply with precisely neither the social contract theories of the Western political thought nor the contract imagined in the divine sovereignty in Islam. Unlike the former, it argues that the agency individual enjoys borrowed from God while unlike the latter, it argues that the individual has the absolute authority to decide on temporal political affairs. However, akin to the argument of divine sovereignty thesis, and distinct from the argument of the Western social contract, Ghannouchi maintains that the contract is not only formed out of fear in a state of 
nature but also informed with the sense of universal brotherhood among Muslims that is inspired by the personal piety. The contract is not only the rational necessity for a stable community, but also it is an integral part of an individual's religiosity.

Moreover, I argue that Ghannouchi’s radical departure from the divine sovereignty thesis and significant contribution to the modern Islamist thought is the argument that shari'a should not be designated as positive codified law, but that should be regarded as the community’s moral guiding principles. The revealed message, for him, should be mediated into the societal, ethical foundation. The objective of it, he further argues, should be human welfare, and that could be ensured through the reinterpretation of shari'a in the present contexts and demands. This departure although gets high appreciation, is undermined from both the ontological and epistemological grounds. Nevertheless, Ghannouchi’s departure could be a starting point for the further development of sovereignty within the Islamic tradition. It is neither necessary to compare with the Western tradition of sovereignty nor obligatory to "invent” popular sovereignty in Islam. Instead, given the distinct nature of Islam as a religion from Christianity, and its different historical tradition, an Islamic model of sovereignty could be imagined. 


\section{CHAPTER V: CONCLUSION}

\section{The Shifting Thought on Islamist Sovereignty: A Normative Promise to Democracy}

Let me briefly summarize the arguments threading through the previous three chapters.

First, I explored the historical intricacies of sovereignty in Western and Islamist political thought. I argued that a historical shift of sovereignty from God to the King to the people in the Western tradition occurred whereas the debates remained limited to the separability/inseparability of religion from politics in Islamic tradition. I also explored the theoretical underpinnings of the major theorists' thought on sovereignty pertinent to the topic of this thesis. This discussion addresses a number of questions, such as who the ultimate sovereign in these theorists' arguments is, on what basis do they determine the relationship between the rulers and the ruled, how do they recognize the individual agency and the sources of rulers’ legitimacy in their theories. Second, I investigated the divine sovereignty theory of Mawdudi and Qutb where I argued that the Islamic concept tawhid is the basis of their argument on sovereignty of God. The divine sovereignty in Islam is derived from faith, instrumentalizing the rationale of the inseparability of Islam from politics whereas in the Western tradition it is the separability of religion from politics that informed popular sovereignty. I also showed how Qutb’s reaction to modernity shaped his argument of divine sovereignty. Finally, I explored Ghannouchi’s theory of sovereignty. I argued that he carries legacies of two debates of Islamist political thought: the separation of religion and politics and the vice-regency of people. I exposed how Ghannouchi’s subscription to these traditions, with his metaphysical understanding of Islam, and support for the siyasa shariiyya tradition shaped his ideas on sovereignty. Unlike the exponents of divine sovereignty, he declares that ummah is the sovereign in the governance of Muslim majority 
countries. The arguments of the preceding three chapters portray a shifting thought of sovereignty in modern Islamist political thought from Mawdudi and Qutb to Ghannouchi.

\section{The Shift}

The exploration of the three Islamist scholars' thoughts on sovereignty demonstrates an ostensible normative shift in the concept of sovereignty in modern Islamist political thought. The shift is from the concept of divine sovereignty propagated by Mawdudi and Qutb, to sovereignty of ummah propagated by Ghannouchi. It is not that all facets of Islamist sovereignty have been radically transformed, some arguments remained unchanged while some radically altered. I have determined six points of departure in modern Islamist political thought on sovereignty. Firstly, although Mawdudi, Qutb, and Ghannouchi rely on the metaphysical account of the totality of existence, their diverse interpretations lead them to different conclusions on sovereignty. Mawdudi and Qutb, based on the Quranic concept of tawhid, argue that God's presence is integral in all aspects of life; God is the ultimate sovereign; God creates everything in this universe, and therefore, the creatures must unquestionably submit to Him in all cases. Consequently, Mawdudi and Qutb further argue that no separation of faith from politics is permissible in Islam. They, accordingly, reject the thought that temporal interpretations could manage the political part of life. The temporal interpretations on political affairs for them is a clear breach of God's ultimate sovereignty that is in Qutb’s word, Jahiliya (ignorance to God). From this premise, they also discard the siyasa shariiyya tradition of Islam. For them, religion was never separated from political thoughts and practices of Islamic tradition and claim that any practice demanding the separate political domain, was “aberration” from authentic Islamic thoughts (Asad 1961). 
Ghannouchi’s theory of sovereignty departs from Mawdudi and Qutb’s on this point. Although he believes in the metaphysical account of God, he argues that the separation of faith from politics should not be interpreted as the betrayal to God's absolute oneness. Ghannouchi argues that political affairs were always managed in temporal manner in Islam that has never undermined God's ultimate sovereignty. He substantiates this claim drawing on the practices of Prophet Mohammad (PBUH), and the subsequent rulers in Islam. Unlike Mawdudi and Qutb, with a firm belief in Islam's siyasa shariiyya tradition, Ghannouchi contends that the governance in Islam has been performed through the practical understanding of the Muslim rulers, as opposed to an entirely theological understanding.

The second departure of Ghannouchi's thought from the divine sovereignty thesis is on the ground of vice-regency in Islam. The advocates of divine sovereignty have been ambivalent on whether individual, ruler or people as a whole are bestowed with viceregency. Mawdudi and Qutb also did not elucidate what specific responsibilities people as the vice-regent of God are permitted to perform. They rhetorically note that people could interpret only the issues that are not specified in the revealed texts. In contrast, Ghannouchi explicitly declares that people are the ultimate vice-regent of God. He does not deny God's ultimate sovereignty, but for him, people as a whole enjoy the full autonomy to decide on political affairs. This autonomy, Ghannouchi argues, is neither inherent to individuals nor derives from nature. Instead, he maintains that people have autonomy because of God.

In addition to these two significant differences, I argue that there is a third aspect of differences between these contending perspectives; that is the question of individual agency. In divine sovereignty thesis, the question of individual agency is quite ambiguous. The proponents argue that any claim for the personal agency is Jahiliya. Their rejection of individual agency 
comes from the assumption that human beings are inherently susceptible to sin. None but only Allah is perfect, He is beyond all errors and aberrations, they argue. Mawdudi notes that it is the autonomous human agency that historically brought injustice to the world. It is also interpreted that the approval of individual agency is to give a human a share to God's ultimate sovereignty that, for the divine sovereignty proponents, is impermissible. However, in contrast to the previous position, Mawdudi and Qutb also empower individuals to decide based on ijtihad on the issues that are not explicitly directed in revealed texts. For example, Mawdudi’s theo-democracy claims that the popular will should elect leadership in a Muslim majority country. Therefore, I argue that in divine sovereignty thesis, individual's limited agency is considered acceptable. Ghannouchi, however, takes a radical stance on the question of individual agency. He claims that a Muslim individual does not enjoy agency in religious matters; he is to submit entirely to God's authority. ${ }^{45}$ But, individual-rational- God-gifted agency is the key to political matters. In a Lockean way, Ghannouchi declares that God's will is embodied in the individual will. What rationally individual decides for societal stability and governance through consensus is not an antithesis to God's will. It is indeed the praxis of the will of God. He reinforces it by saying that while making laws and implementing those, the people in office should neither listen to the religious department of a state nor the traditional ulama's expositions on issues; but they should employ their reason to decide on human welfare (al-maslaha).

The fourth point of departure of Ghannouchi’s sovereignty from the divine sovereignty expositions is on the ground of social contract. For him, individuals enter concurrently in two contracts: one with God- a faith inspired contract that is accomplished through the complete submission to God; the other is a worldly contract - entirely civil where rulers and ruled engage in a contract for peaceful human co-existence and welfare. Mawdudi and Qutb have a reservation 
for the second kind of contract which is attached to Ghannouchi's position on sovereignty. For Mawdudi and Qutb, it is contrary to the fundamental ethos of Islam, tawhid from which the ultimate sovereignty of God emerges. Qutb argues that all worldly relations - individual with God, with other individuals, with rulers, with other creatures, are determined by God's message, and informed by the doctrine of the comprehensive unity of God.

Nevertheless, Ghannouchi, Mawdudi, and Qutb agree on the point of a social contract in Islamic societies. The social contract in their articulation is fundamentally different from the Western imagination of social contract. In the Western thought, it is the existential insecurity in the state of nature that drives human beings to engage in a contract for security and stability. The contract in the Western tradition is entirely this-worldly, a matter of individual rational choice. A rational, human-inspired morality contributes to social cohesions. In the Islamic political thought, it is not the existential insecurity that leads individuals to engage in a social contract, but also the faith inspired morality brings them into a relationship of the universal brotherhood. The assumption is that faith-inspired societal moral base in Islam would better contribute to the social cohesion and develop a stable social sphere. The social contract in Islamic communities is a rational choice, and an integral part of individual faith as Ghannouchi would argue.

The fifth departure on the thoughts on the sovereignty of Islamist scholars I explored is how Islamist sovereignty contests popular sovereignty. Qutb radically rejects popular sovereignty for its, what he calls, the direct challenge to God's sovereignty. Euben rightly argues that Qutb’s absolute divine sovereignty is a reaction to the concept of popular sovereignty in the Western tradition. For Qutb, what popular sovereignty does in the name of human agency and freedom jeopardizes God's authority and God's prescribed Islamic moral societal authority. It marginalizes the revealed truth and pushes society into moral bankruptcy. Mawdudi's resistance 
to popular sovereignty and his favor for divine sovereignty also emerge from the moral ground of Islam. Mawdudi declares that popular sovereignty cannot contribute to the moral and ethical advancement of the human beings; it instead ends up with the enslavement of humans to their selfish desires. It is under God's omnipresent existence and His moral and ethical ambit revealed in scriptural texts, individuals are free and equal and co-exist harmoniously. On the other hand, Ghannouchi makes a distinctively different argument on Islamist sovereignty that neither entirely rejects popular sovereignty nor undermines the sovereignty of God. He argues for the sovereignty of ummah, but it is not in the sense that people enjoy absolute authority without divine accountability. The authority people assert to manage political affairs is borrowed from God, not inherent to them as a natural right as it is claimed in the popular sovereignty. Moreover, unlike the Western political thought, Ghannouchi wants the temporal affairs to be informed by the faith-inspired ethicality.

Finally, discussions on the political thoughts of Mawdudi and Qutb on the one hand and Ghannouchi, on the other also reveals a difference in Islamists' interpretations of shari'a. Both the proponents of divine sovereignty and the sovereignty of ummah place shari'a in ultimate supremacy, above all laws-the highest authority of governance. They, however, present it in different manners. While divine sovereignty proponents address shari' $a$ as the positive codified laws, Ghannouchi perceives it as the moral guide for individuals. The former argues that the state should implement shari'a from above whereas the latter claims the opposite; shari'a would inform individual from the bottom. Mawdudi and Qutb claim that rulers as the deputies of God are entitled to formulate laws only if those are not explicitly directed in the Quran and Hadith. For that, they must also follow the established practices of Islamic jurisprudence, i.e. ijtihad, ijma, and qiyas. Mawdudi and Qutb perceived shari'a as a comprehensive body of laws that 
cover nearly every aspect of life. In contrast, in Ghannouchi’s civil state rulers based on ummah's mandate are free to make laws for human welfare. They should neither be guided by ulama nor by the state's religious department. Ghannouchi argues that as God's creature and with rationality gifted from God, rulers should formulate laws. Although rulers do not accept shari'a as coded laws, shari'a informs laws they make as a part of their individual faith. The assumption is that if individual becomes religious, that religiosity would inform state affairs, albeit indirectly.

\section{The Democratic Promise}

How does the shifting thought on the sovereignty in Islamist political thought contribute to the democratization in Muslim majority countries? I argue that it has a significant normative contribution to the theoretical debates of Islamist thought on democracy.

The fundamental paradox for Islamist political thought has been to reconcile God's ultimate sovereignty in Islam with the concept of popular sovereignty in liberal democracies. The ambivalence of divine sovereignty advocates-rejecting popular sovereignty on the one hand, and tacitly referring to people as the vice-regent of God, on the other-did not contribute much to resolve the paradox.

The contribution of Ghannouchi is that he unambiguously declares the sovereignty of ummah and shows a way out of the Islamist paradox. Ghannouchi did not reject God's sovereignty to accept the popular sovereignty of liberal democracy; rather, he argues that people’s sovereignty could be acknowledged, keeping God’s ultimate sovereignty sacred. The contention is that people are sovereign to decide on temporal-political affairs. It, however, does not contradict God's ultimate sovereignty because, for Ghannouchi, people’s sovereignty is borrowed from God. His argument is akin to Khan’s that when the Quran says that sovereignty 
belongs to God, it means that sovereignty has already been deputized in the form of human agency (Khan, 2004). Ghannouchi articulates that reason and revelation are not contradictory in Islam, rather they could co-exist and inform each other. Ghannouchi does not argue for the ultimate sovereignty of people similar to Western political thought. His position could be argued to be more Lockean who argues that people's sovereignty does not contest the ultimate sovereignty of God. Locke's legitimate government is one where political authority can be morally justified with only the voluntarily expressed consents of the governed. These consents are not beyond God's providence that implies that Locke's political authority could be supported on both theological and rational grounds (Hashmi, 2009).

Whether these arguments will be convincing to the Islamists who fundamentally believe that politics must be inspired by faith in Islam is an open question. Ghannouchi’s contribution, however, is that it clearly argues for the faith's separation from the political practices of Muslim majority conutries. With a metaphysical understanding of faith and the historical practices of siyasa shariiyya tradition of politics, Ghannouchi more convincingly argues that faith and politics have been always separated in Islam. Keeping the faith part of God unscathed, he maintains that politics could be practiced with human intellect. A similar argument could be found in the recent theoretical debates on democracy in Islam. ${ }^{46}$ Fadl, like Ghannouchi, notes that a basic departure from the traditional Islamist interpretations of democratic attributes is the assumption that perhaps God does not regulate all affairs of human life. Rather, for Fadl, it could be the case that human being is permitted to regulate their own affairs until that does not violate the fundamental moral and ethical attributes prescribed by God (Fadl, 2004). Ghannouchi, however, does not argue for a watertight compartmentalization of religion and politics. He rather wants a formal separation of politics from religion in his civil state to safeguard state from any 
particular religion's dominance while he believes that religion as a part of personal faith would always inform politics (Stepan, 2012).

Ghannouchi's reinforcement on separation theory and argument for the sovereignty of ummah contests Islamists' arguments that “only legitimate source of law is the divine texts and that human experience and intellect are irrelevant to the pursuit of the divine will” (Fadl, 2004, p. 9). Based on this thesis, they get leverage to reject democracy as a man-made model of governance that challenges God's command as revealed in Qutb’s writings. Against this backdrop, Ghannouchi with the historical practice of ruler and ruled contract in Sunni Islam, argues that the governance with ummah's consent was never thought as a contradiction to God's will. Therefore, the ruler and ruled relation in his "Islamic democracy" which is established based on shari'a and shura, would be based on a worldly contract ('aqd) that used to be in practice in the governance of Islamic caliphates. Caliphs used to get the allegiances (bay'a) of his subjects on a contract with a promise of welfare, territorial security and the implementation of God's law. The ulama used to determine the conditions of the contract. They were the guardians to oversee if rulers violated God's laws. The rulers were granted broad discretion over matters of human welfare. What should be the place of shari'a in a liberal democracy is a long debate in Muslim majority countries. The conventional Islamists argument is that shari'a should be implemented as codified positive laws that came in a direct challenge to essential attributes to liberal democracy.

Ghannouchi's argument on shari'a in a democratic state, although engendered many inconsistencies as I have discussed in chapter 4, sheds a constructive light on the debate. He sees shari' $a$ as a larger moral guideline for governance of an Islamic democracy and the objective of it is to ensure the maximum human welfare. Instead of seeing shari'a as a body of laws, 
Ghannouchi claims that it should be treated as the God's “comprehensive message of mercy and justice to all human being” (Tamimi, 2001, p. 91). This interpretation of shari'a neither contests human agency nor contradicts the fundamental freedom of liberal democracy as it was the case of the traditional interpretations of shari'a. Ghannouchi even clearly declares that within the ultimate sovereignty of God, and His divine guidelines, it is possible for states to ensure citizens' "right to embrace or leave a religion or belief” (Ghannouchi, 2018, p. 22). He, unlike the traditional claim that shari'a interpretations are universal and remains valid across time and space, comments that shari'a needs to be interpreted based on changing contexts and time. The messages of shari'a such as justice, is universal to all human being, but other aspects are contextual and time specific. His emphasis on the human interpretation of shari' $a$ and attempt to draw the moral and ethical values from shari'a could be seen as a substantial contribution to the democratization of Muslim majority countries. Esposito mentions that accentuating on fiqh, the human interpretation and application of shari'a over shari'a as a coded divine law is fundamental to the democratic future of these countries (Esposito, 2004). Ghannouchi's attempt to derive democratic values from Islamic texts and practices, and to underscore on moral and ideological institutions of democracy could be a new path to think democracy in Muslim majority countries.

Finally, Ghannouchi is not the only scholar who brings the issues discussed above to forefront those have significant implication to the normative understanding of democracy in Muslim majority countries. There are many scholars as I have mentioned such as John L. Esposito, Abdolkarim Soroush, Khaled Abou El Fadl, among others who elucidate democratic promises in Muslim majority countries from multiple vantagepoints. These scholars' arguments, however, are often undermined by Islamists arguing that those are not derived from the Quran 
and Islamic traditions (Bukay, 2007). Ghannouchi's arguments are less likely to be rejected from that ground as he attempts to bring the Quranic explanations and Islamic tradition of governance together to argue for sovereignty of ummah and associated issues. Therefore, the democratic promise Ghannouchi brings from within Islamist thought is likely to be more sustainable. 


\section{REFERENCES}

Abisaab, R. J. (2003). Converting Persia: Religion and Power in the Safavid Empire. New York: I.B. Tauris.

Agrama, H. A. (2012). Questioning Secularism: Islam, Sovereignty, and the Rule of Law in Modern Egypt. Chicago and London: The University of Chicago Press.

Ahmad, I. (1942). Social Contract and the Foundations of the Islamic State. The Indian Journal of Political Science, 4(2), 132-169.

Ahmad, I. (1958). Sovereignty in Islam. Pakistan Horizon, 11(3), 141-146.

Ahmad, M. (1965). Sovereignty of God in the Constitution of Pakistan: A Study in Conflict of Traditionalism and Modernism. Islamic Studies, 4(2), 201-212.

Akbarzadeh, S. (2012). The paradox of political Islam. In S. Akbarzadeh, Routledge Handbook of Political Islam (pp. 1-8). London and New York: Routledge.

Alajmi, A. (2011). 'Ulama and caliphs new understanding of the "God's caliph” term. Journal of Islamic Law and Culture, 12(1), 102-1012.

Allen, J. W. (1928). A History of Political Thought in the Sixteenth Century. London: Methuen and Co. Ltd.

An-Na'im, A. A. (2008). Islam and the Secular State: Negotiating the Future of Shari'a. Cambridge, Massachusetts, and London, England: Harvard University Press.

Arnold, T. W. (1924). The Caliphate. Oxford: The Clareton Press.

Asad, M. (1961). The Principles of State and Government in Islam. Berkeley and Los Angeles: University of California Press. 
Bergman, D. (2019, February 14). aljazeera.com. Retrieved March 4, 2019, from aljazeera.com: https://www.aljazeera.com/news/2019/02/senior-leader-bangladesh-jamaat-abdur-razzaqresigns-190216073123676.html

Black, A. (2011). The History of Islamic political thought: From Prophet to the Present. Edinburg: Edinburg University Press.

Bodin, J. (1955). Six Books of the Commonwealth. (M. J. Tooley, Trans.) Oxford: Basil Blackwell.

Brown, L. C. (2000). Religion and State: Muslim Approaches to Politics. New York: Columbia University Press.

Casanova, J. (1994). Public Religion in the Modern World. Chicago and London: University of Chicago Press.

Constitute. (2011). Retrieved March 3, 2019, from constituteproject.org: https://www.constituteproject.org/constitution/Morocco_2011.pdf?lang=en

Constitute. (2014). Retrieved March 3, 2019, from constituteproject.org: https://www.constituteproject.org/constitution/Tunisia_2014.pdf

Cook, M. (2014). Ancient Religions, Modern Politics: The Islamic Case in Historical Perspective. Princeton: Princeton University Press.

Copson, A. (2017). Secularism: Politics, Religion and Freedom. Oxford and New York: Oxford University Press.

Croker, L. G. (1968). Rousseau's Social Contract: An Interpretative Essay. Cleveland: The Press of Case Western Reserve university.

Crone, P., \& Hinds, M. (1986). God's Caliph: Religious authority in the first century in Islam. London and New York: Cambridge University Pres. 
Dallmayr, F. (1997). Introduction: Toward a Comparative Political Theory. The Review of Politics, 59(3), 421-427.

Donker, T. H. (2013). Re-emerging Islamism in Tunisia: Repositioning Religion in Politics and Society. Mediterranean Politics, 18(2), 207-224.

Dunn, J. (1995). The Political Thought of John Locke. Cambridge: Cambridge University Press.

Elshtain, J. B. (2008). Sovereignty: God, State and Self. New York: Basic Books.

El-Solh, C. F. (1993). Be true to your culture: Gender tensions among Somali Muslims in Britain. Immigrants \& Minorities, 12(1), 21-46.

Elton, G. R. (2002). Studies in Tudor and Stuart Politics and Government: Papers and Reviews 1946-1972. Cambridge and New York: Cambridge University Press.

Enayat, H. (1982). Modern Islamic Political Thought: The Response of the Shi'a and Sunni Muslims to the. London and Basingstoke: The Macmillan Press Ltd.

Engster, D. (2001). Divine Sovereignty: The Origin of Modern State Power. Dekalb: Northern Illinois University Press.

Esposito, J. L. (1984). Islam and politics. New York: Syracuse University Press.

Esposito, J. L. (2004). Practice and Theory. In K. A. Fadl, Islam and the Challenge of Democracy (pp. 93-100). Princeton and Oxford: Princeton University Press.

Esposito, J. L., \& Voll, J. O. (1996). Islam and democracy. New York: Oxford University Press. Esposito, J. L., \& Voll, J. O. (2001). Makers of contemporary Islam. New York: Oxford University Press.

Euben, R. L. (1999). Enemy in the Mirror: Islamic Fundamentalism and the Limits of Modern Rationalism: A Work of Comparative Political Theory. Princeton, New Jersey: Princeton University Press. 
Fadl, K. A. (2004). Islam and the Challenges of Democracy. In K. A. Fadl, Islam and the Challenges of Democracy: A Boston Review Book (pp. 3-48). Princeton and Oxford: Princeton University Press

Fisher, M. H. (2016). A Short History of the Mughal Empire. London and New York: I. B. Tauris.

Freeden, M., \& Vincent, A. (2013). Comparative Political Thought: Theorizing Practices. London and New York: Routledge.

Gencer, B. (2010). Sovereignty and the Separation of Powers in John Locke. The European Legacy, 3, 323-339.

Ghannouchi, R. (1993). Al-Huriyat Al-‘Ammah fi Al-Dawla al-Islamiyah. Beirut: Markaz Dirasat al-Wihdah al-`Arabiyah.

Ghannouchi, R. (2006). The Participation of Islamists in a Non-Islamic Government. In J. L. John J. Donohue, Islam in Transition: Muslim Perspectives (pp. 271-278). London and New York: Oxford University Press.

Ghannouchi, R. (2013). The State and Religion in the Fundamentals of Islam and Contemporary Interpretation. Contemporary Arab Affairs, 6(2), 164-171.

Ghannouchi, R. (2016, October 1). From Political Islam to Muslim Democracy. Foreign Affairs, pp. 58-75.

Ghannouchi, R. (2018). Ennahad’s Democratic Commitments and Capabilities. In A. Stephan, Democratic Transition in the Muslim World: A Global Perspective (pp. 15-29). New York: Columbia University Press.

Gibb, H. A. (1945). Modern Trends in Islam. Chicago: University of Chicago Press. 
Glenn, G. D. (1984). Inalienable Rights and Locke's Argument for. Journal of Politics, 4, 80115.

Gorski, P. S. (2000). Historicizing the Secularization Debate: Church, State, and Society in Late Medieval and Early Modern Europe, ca. 1300 to 1700. American Sociological Review, 65(1), 138-167.

Grant, R. W. (1987). John Locke's Liberalism. Chicago: University of Chicago Press.

Hallaq, W. B. (1997). A History of Islamic Legal Theories: An Introduction to Sunni Usul Alfiqh. Cambridge: Cambridge University Press.

Hamid, S. (2016). Islamic Exceptionalism: How the Struggle Over Islam Is Reshaping the World. New York and Oxford: Oxford University Press.

Hamid, S., \& McCants, W. (2017). Rethinking Political Islam. New York: Oxford University Press.

Hashmi, N. (2009). Islam, Secularism, and Liberal Democracy: Toward a Democratic Theory for Muslim Societies. New York and Oxford: Oxford University Press.

Hassan, M. K. (2003). Mawdudi’s Thought on Muslims in Southeast Asia: A Brief Survey. The Muslim World, 93(3/4), 429-464.

Heywood, A. (2004). Political Theory: An Introduction. New York: Palgrave Macmillan.

Hinds, P. C. (1986). God's Caliph: Religious authority in the first century in Islam. London and New York: Cambridge University Press.

Hinsley, F. H. (1986). Sovereignty. Cambridge and New York: Cambridge University Press.

Hobbes, T. (1952). Leviathan. Oxford: Clarendon Press.

Holmes, S. (1988). Jean Bodin: The Paradox of Sovereignty and the Privatization of Religion. Nomos, 30, 5-35. 
Howard, D. A. (2017). A History of the Ottoman Empire. New York: Cambridge University Press.

Idris, J. S. (1990). Is man the Viceregent of God? Journal of Islamic Studies, 1, 99-111.

Iqbal, M. (1965). The Reconstruction of Religious Thought in Islam. Lahore: Shaikh Muhammad Ashraf.

Jackson, R. (2011). Mawlana Mawdudi and Political Islam: Authority and the Islamic State. New York: Routledge.

Jackson, R. H. (1990). Quasi-States: Sovereignty, International Relations and the Third World. Cambridge: Cambridge University Press.

Jalal, A. (2000). Self and Sovereignty Individual and Community in South Asian Islam Since 1850. New York and London: Routledge.

Jawad, N. (2013). Democracy in Modern Islamic Thought. British Journal of Middle Eastern Studies, 40(3), 324-339.

Johnson, J. T. (2014). Sovereignty: Moral and Historical Perspective. Washington, DC: Georgetown University Press.

Kantorowicz, E. H. (1957). The King’s Two Bodies. Princeton, NJ: Princeton University Press. Keohane, N. O. (1980). Philosophy and State in French. Princeton: Princeton University Press. Khan, M. A. (2004). The Primacy of Political Philosophy. In K. A. Fadl, Islam and the Challenge of Democracy (pp. 63-68). Princeton and Oxford: Princeton University Press.

Khan, M. A. (2005). Sovereignty in Modernity and Islam. East- West Review, 1(2), 43-57.

Khan, M. A. (2006). Islamic Democratic Discourse: Theory, Debates, and Philosophical Perspectives. New York: Lexington Books. 
Khatab, S. (2002). "Hakimiyyah" and "Jahiliyyah" in the Thought of Sayyid Qutb. Middle Eastern Studies, 38(3), 145-170.

Khatb, S. (2006). The Power of Sovereignty: The Political and Ideological Philosophy of Sayyid Qutb. Oxon and New York: Routledge.

Kramer, G. (2010). Makers of the Muslim World: Hasan al-Banna. London and New York: One World.

Krasner, S. D. (1999). Sovereignty: Organized Hypocrisy. Princeton, NJ: Princeton University Press.

Krasner, S. D. (2004). Sharing sovereignty: new institutions for collapsed and failing states. International Security, 29(2), 85-120.

Lapidus, I. M. (1975). The Separation of State and Religion in the Development of Early Islamic Society. International Journal of Middle East Studies, 6, 363-385.

Lapidus, I. M. (1996). State and Religion in Islamic Societies. Past and Present, 151, 3-27.

Lewis, B. (1988). The Political Language of Islam. Chicago and London: University of Chicago Press.

Lloyd, H. A. (1991). Sovereignty: Bodin, Hobbes, Rousseau. Revue Internationale de Philosophie 45(179), 353-379.

Locke, J. (1988). Two Treatises of Government. (P. Laslett, Ed.) Cambridge and New York: Cambridge University Press.

Mahmood, S. (2004). Is liberalism Islam's only answer? In K. A. Fadl, Islam and Challenges of Democracy: A Boston Review Book (pp. 74-77). Princeton and London: Princeton University Press. 
March, A. F. (2010). Taking People As They Are: Islam As a "Realistic Utopia” in the Political Theory of Sayyid Qutb. The American Political Science Review, 104(1), 189-207.

March, A. F. (2013). Genealogies of Sovereignty in Islamic Political Theology. Social Research, 80(1), 293-320.

March, A. F. (2015a, September 3). The problem of Sovereignty in Modern Islamic Political Thought. Retrieved from Columbia University Political Theory Workshop: https://cuptw.wordpress.com/archives/fall-2015/

March, A. F. (2015b). Naturalizing Shari'a: Foundationalist Ambiguities in Modern Islamic Apologetics. Islamic Law \& Society, 22(1-2), 65-85.

March, A. F. (2018b, May 23). Retrieved from Webster University: http://webster.ac.at/event/caliphate-man-guest-lecture-dr-andrew-march

March, A. F. (2018a, April 28). Challenges to Democratic Consolidation in Tunisia. Washington DC, United States: CSID 19th Annual Panel 3. Retrieved January 5, 2019, from https://www.youtube.com/watch?v=Kxoi5XzESyI\&t=604s

Mawdudi, S. A. (1967). The Islamic Law and Constitution. (K. Alam, Trans.) Lahore: Islamic Publications Ltd.

Mecham, Q. (2014). Islamist parties as Strategic Actors: Electoral participation and Its Consequences. In Q. M. Hwang, Islamists Parties and Political Normalization in the Muslim World (pp. 17-39). Philadelphia: University of Pennsylvania Press.

Merriam, C. E. (1968). History of Theory of Sovereignty since Rousseau. New York: A M S Press.

Metcalf, B. D. (1982). Islamic Revival in British India: Deoband, 1860-1900. Princeton: Princeton University Press. 
Middleton, K. W. (1969). Sovereignty in Theory and Practice. In W. J. Stankiewicz, In Defense of Sovereignty (pp. 132-159). New York: Oxford University Press.

Moaddel, M., \& Talattof, K. (2000). Contemporary Debates in Islam: An Anthology of Modernist and Fundamentalist Thought. (M. Moaddel, \& K. Talattof, Eds.) New York: Palgrave Macmillan.

Nasr, S. V. (1996). Mawdudi and the Making of Islamic Revivalism. Oxford and New York: Oxford University Press.

Opwis, F. (2005). Maṣlaḥa in Contemporary. Islamic Law and Society, 12(2), 182-223.

Osman, F. (2003). Mawdudi's Contribution to the Development of Modern Islamic Thinking in the Arabic-Speaking World. The Muslim World, 93(3/4), 465-485.

Pasha, M. K. (2013). Modernity’s Islamicist: Sayyid Qutb’s Theocentric Reconstruction of Sovereignty. In S. C. Wagner, Modernity’s Classics (pp. 101-122). Heidelberg: SpringerVerlag Berlin Heidelberg.

Pasha, M. K. (2018). Political theology and sovereignty: Sayyid Qutb in our times. Journal of International Relations Development, 1-18. doi:https://doi.org/10.1057/s41268-0180151-3.

Philpot, D. (2001). Revolutions in Sovereignty: How Ideas Shaped Modern International Relations. Princeton, NJ: Princeton University Press.

Philpott, D. (2007). Explaining the Political Ambivalence of Religion. American Political Science Review, 101(3), 505-525.

Quraishi-Landes, A. (2015). The Sharia Problem with Sharia Legislation. Ohio North University Law Review, 545-566. 
Qureshi, I. H. (1976). Sovereignty in an Islamic State. In S. A. Mujahid, Ideological Orientation of Pakistan (pp. 101-112). Karachi: National Book Foundation.

Qutb, S. (n.d.). Milestone. Damascus: Dar Al-llm.

Rahman, F. (1970). Islam and the Constitutional Problem of Pakistan. Studia Islamica, 32, 275287.

Rahman, M. M. (2014). Religion and Politics in South Asia by Ali Riaz (ed.). Strategic Analysis, 38(1), 119-121. Retrieved 2 18, 2019, from http://tandfonline.com/doi/full/10.1080/09700161.2014.863506

Razek, A. A. (2013). Islam and the Foundations of Political Power. (A. Filali-Ansary, Ed., \& M. Loutfi, Trans.) Edinburgh: Edinburgh University Press.

Rousseau, J. J. (1997). The Social Contract and Other Later Political Writings. (V. Gourevitch, Ed.) New York: Cambridge University Press.

Rousseau, J. J. (1997). The Social Contract and Other Later Political Writings. (V. Gourevitch, Ed.) New York: Cambridge University Press.

Rubin, U. (2003). Prophets and Caliphs: The Biblical Foundations of the Umayyad Authority. In H. Berg, Method and Theory in the Study of Islamic Origins (pp. 73-100). Leiden, Boston: Brill.

Sadek, K. (2012). Islamic Democracy: The Struggle for and Limits of Recognition. Unpublished PhD Dissertation. Graduate School of Arts and Sciences, Georgetown University.

Sadek, K. (2014). Maṣlaḥa and Rachid al-Ghannushi’s Reformist Project. In A. Duderija, Maqasid al-Shari'a and Contemporary Reformist Muslim Thought: An Explanation (pp. 151-175). New York: Palgrave Mcmillian. 
Schmitt, C. (1985). Political Theology: Four Chapters on the Concept of Sovereignty. (G. Schwab, Trans.) Cambridge. Massachusetts, London, England: MIT Press.

Scott, J. T. (2000). The Sovereignless state and Locke's language of obligation. American Political Science Review, 94(3), 547-561.

Shapiro, I. (2003). John Locke’s Democratic Theory. In J. Locke, \& I. Shapiro (Ed.), Two Treaties of Government and A Letter Concerning Democracy (pp. 309-340). New Heaven and London: Yale University Press.

Sherwani, H. K. (1942). Studies in Muslim Political Thought and Administration. Lahore: S. H. Mahmud Ashraf.

Simmons, A. J. (1993). On the Edge of Anarchy: Locke, Consent, and the Limits of Society. Princeton, NJ: Princeton University.

Skinner, Q. (2002). Hobbes and Civil Science. In Q. Skinner, Hobbes and the purely artificial person of the state (pp. 177-208). New York: Cambridge University Press.

Skinner, Q. (2010). The sovereign state: a genealogy. In H. K. Skinner, Sovereignty in Fragments: The Past, Present and Future of a Contested Concept (pp. 26-46). Cambridge and New York: Cambridge University Press.

Sorour, S. (2013, February 2). Al Masryalyoum. Retrieved March 3, 2019, from almasryalyoum.com: https://www.almasryalyoum.com/news/details/285814

Soroush, A. (2000). Reason, Freedom, and Democracy in Islam: Essential Writings of Abdolkarim Soroush. (M. S. Sadri, Trans.) New York and Oxford: Oxford University Press.

Starobinski, J. (2002, 4 25). Rousseau and Revolution. New York Review of Books. Retrieved from: https://www.nybooks.com/articles/2002/04/25/rousseau-and-revolution/ 
Stepan, A. (2012). Tunisia's Transition and the Twin Tolerations. Journal of Democracy, 23(2), 89-103.

Tamimi, A. S. (2001). Rachid Ghannouchi: A Democrat Within Islamism. Oxford and New York: Oxford University Press.

Tamimi, A. S. (2007). Islam and Democracy from Tahtawi to Ghannouchi. Theory, Culture \& Society, 24(2), 39-58.

Toth, J. (2013). Sayyid Qutb: The Life and Legacy of a Radical Islamic Intellectual. New York and London: Oxford University Press.

Weithman, P. (2006). Augustine's political philosophy. In D. V. Stump, The Cambridge Companion to Augustine (pp. 231-250). Cambridge and New York: Cambridge University Press.

Willis, J. (2010). Debating the Caliphate: Islam and Nation in the Work of Rashid Rida and Abul Kalam Azad. The International History Review, 32(4), 711-732.

Wolf, A. (2017). Political Islam in Tunisia: The History of Ennahda. Oxford and New York: Oxford University Press.

Yamane, D. (1997). Secularization on Trial: In Defense of a Neo-Secularization Paradigm. Journal for the Scientific Study of Religion, 36, 109-122.

Zaman, M. Q. (2002). Ulema in Contemporary Islam: Custodian of Change. Princeton and Oxford: Princeton University Press. 


\section{APPENDIX: ENDNOTES}

${ }^{1}$ Sunni and Shia denomination divide in Islam emerged in Islam just after the death of Mohammad. The group who believed that he did not nominate any successors and based on consensus the next ruler should be selected. On the other hand, another dominant denomination Shia believed that Mohammad's son in law Ali should be the ruler in heredity right. Eventually, it became a big divide and bloody battle between the groups took place historically, and still today the trace of antagonism can be easily identified across the world. For a brief overview, see The SunniShia Divide, https://www.cfr.org/interactives/sunni-shia-divide\#!/sunni-shia-divide (accessed on August 20, 2018). In this thesis, when I write that Islamists’ sovereignty in Sunni Islam, I do not mean that all Sunni Islamists believed in divine sovereignty. Within Sunni Islam there are various beliefs regarding sovereignty. Therefore, I particularly mean the Islamists ideologues and political parties who argue for divine sovereignty.

${ }^{2}$ I use the concept liberal democracy practiced in Muslim majority countries in more limited-functional sense in this thesis. The attributes of liberal democracy such as people's participation, separation of power, universal franchise and so forth those are relevant to the subject matter of the present topics are emphasized in this thesis. Some other concepts and concerns such as human rights, civil liberties, civil rights, personal freedom those are subject to intense controversies are not accentuated here.

${ }^{3}$ Islamist political parties began accepting liberal democracy, and some of them, were able to form governments. Their participation in elections has become the norm in a wide variety of countries, from Egypt to Indonesia, and Morocco to Pakistan (Mecham, 2014). Islamist parties across the world such as Justice and Development Party (AKP) of Turkey, Ennahda of Tunisia, Al-Wasat Party of Egypt are redefining their ideological orientations and rethinking their strategies in the larger political picture of the world (Mecham, 2014). Some of them, for example Ennahda, formally discontinued to define themselves as Islamist political parties (Ghannouchi, 2016). These parties seldom refer to shari'a law or other controversial Islamic jurisprudence. They intend to function as a political party prioritizing democratic values and emphasizing economic and welfare issues. Moreover, the 2012 Constitution of Egypt, written under the auspices of an Islamist political party Muslim Brotherhood and finalized in 2014, unreservedly accepted popular sovereignty. In 2013, the longtime Muslim Brotherhood activist and Freedom and 
Justice Party (FJP) vice-chair Issam al-Aryan implored that "the new constitution has delegated sovereignty [siyada] to the people [despite] the existence of those who place God in opposition to the people” (Sorour, 2013). The article 4 of the constitution declares, "Sovereignty belongs to the people alone, which exercises it and protects it." And most importantly, the article 3 of the Tunisian constitution of 2014 drafted under the aegis of the country's "Islamist” Ennahda party, "the people are sovereign and the source of authority, which is exercised through the peoples’ representatives and by referendum” (Constitute, 2014). Similarly, Article 2 of the new Moroccan Constitution says: "Sovereignty belongs to the nation (Ummah in Arabic) who exercise it directly through referendum and indirectly through its representatives” (Constitute, 2011).

${ }^{4}$ Salafiyya, a modern Islamist movement emerged in the second half of the $19^{\text {th }}$ century, engaged in the debates on perplexing issues as the rise of the rational sciences and their implications for the Islamic belief system, the historical roots of Muslim decadence, the apparent contradiction between the Islamic law and principles and how those could be contextualized in the light of European thoughts. These debates were led by Jamal al-Din al-Afghani and Mohammad Abdhu, a brief account of their thought could be found: (Moaddel \& Talattof, 2000), Chapter one, four and five.

${ }^{5}$ Caliphate has multiple meanings and interpretations. Ideally, it is an Islamic state under the tutelage of an Islamic leadership, known as Caliph, who is recognized as the religious inheritor of Prophet Mohammad. Historically, nearly all Muslim dynasties and Empires claimed them as the successor of Mohammad. Caliphate is a multi-ethnic, transnational governance mechanism where the Caliph is considered as the leader of the entire ummah. For a brief history and controversies over Caliphate, consult: (Arnold, 1924); (Crone \& Hinds, 1986).

${ }^{6}$ For him, the Islamic state or caliphate would be based on the consensus (ijma) of the jurists of the four major legal schools such as Hanafi, Maliki, Hanbali, and Shafi. In his formulation, "the most important criteria were that the caliph evinces 'independent knowledge expressed as independent reasoning (ijtihad)' and that he traces his descent to the Prophet Muhammad’s Quraysh tribe” in (Willis, 2010, p. 719) 
${ }^{7} \mathrm{~A}$ civil state is a nation-state guided by Islamic norms and ethos. Shari'a will not be the positive law of a civil state, but those would be transformed as the social principles, what he calls, “transforming shari'a into ummah.” In a civil state religion would be separated from politics. For details: (Ghannouchi, 2016, 2018).

${ }^{8}$ For Ghannouchi, French secularism is totally unacceptable. He, however, would accept the American secularism where state would remain neutral and safeguard the peaceful practices of all religions. Public sphere could be religious and state apparatuses could be informed by religious morality indirectly. For details: (Ghannouchi, 2016, 2018).

${ }^{9}$ The entire thesis of divine sovereignty in Islam of Mawdudi and Qutb is based on the concept tawhid where oneness of God's sovereignty in theological aspects is transformed to the political aspect. The chapter three of this thesis offers a detailed discussion of this account.

${ }^{10}$ The contribution, influence, and lineage of Mawdudi and Qutb in the $20^{\text {th }}$ century Islamist movements would be found: (Jackson, 2011); (Nasr, 1996); (Euben, 1999); (March, 2010); (Toth, 2013).

${ }^{11}$ Shorter Oxford English Dictionary (volume 2, fifth edition), New York and London: Oxford University Press, 2002.

12 There are vibrant debates against this claim of complete separation of temporal and spiritual in the Western political tradition as well that got momentum with the popularization of Carl Schmitt’s term "political theology.” By this concept he draws attention to the fact that a theological spirit underlies all seemingly modern political concepts such as “sovereignty, contract, state, etc.” (Schmitt, 1985). In the present thesis I am not entering these debates as my attempt here is to look at how the already established popular sovereignty is debated in the modern Islamist political thought.

${ }^{13}$ The four guided Caliphs are also known as Rashidun Caliphs (Rightly Guided Caliphs) are the Caliphs who ruled the 30 years reign after the death of Islamic Prophet Mohammad (PBUH). They are: Abu Bakr ruled from 632 to 
634; Umar ibn al-Khattab (also spelled as Omar) ruled from 634 to 644; Uthman ibn Affan (also spelled as Osman) ruled from 644 to 656; and, Ali ibn Abi Talib ruled from 656 to 661.

${ }^{14}$ Three major Empires in Islam were Safavid, Ottoman, and Moghul Empires. Safavid Empire (1501-1736) is a Persian Empire which established Shia Islam as the official religion of the Empire. It was credited for significant achievement and practices in the field of art, literature, medical practices, and particularly for a strong bureaucracy based on checks and balances. For details consult, (Abisaab, 2003). Ottoman Empire (1299/ 1301-1922) is the biggest Islamic multinational, multilingual empire ranging most of Southeast Europe, parts of Central Europe, Western Asia, parts of Eastern Europe and the Caucasus, North Africa and the Horn of Africa. It was inspired and sustained by Islamic ethos and institutions. Here among other practices, significant was that religious, ethnic, and geographical minorities were allowed to govern their own affairs to some extent. For details, (Howard, 2017). Mughal Empire (1526-1857) ruled in the Indian subcontinent where its centralized government, spread Islamic arts and culture, and mostly known for its religious tolerance. For details, (Fisher, 2016).

${ }^{15}$ The separation thesis is highly debated, and many recent scholars argue that religion and politics were not separated in the process of the Protestant Reformation. Many Reformation historians now argue that the fragmentation of the Western church stimulated a tighter relationship between church and state. It is also claimed that the process profoundly increased the authority of religious elites and institutions in all areas of social and political life. On the other hand, many scholars maintain that it has changed the dimension of religion and politics interaction, did not separate the two. For details see. (Gorski, 2000, pp. 138-143); (Casanova, 1994); (Yamane, 1997).

${ }^{16}$ Crone and Hinds (1986:2) argue that Ali although was Mohammad's companion and his kinsman did not get a general acceptance regarding his both religious and political authorities, I did not underscore on that debate as nearly all early researches agree that Ali, like other three, was a rightly guided caliph in Islam. For details, some of the following research could be consulted: (Lewis, 1988), (Brown, 2000), (Razek, 2013), (Gibb, 1945).

${ }^{17}$ This is one of the two significant traditions of shari'a interpretations. It means laws which created by temporal rulers for public good based on experiences and practices of governance. It has been discussed in detail in chapter three of the present thesis. Also, consult for details, (Quraishi-Landes, 2015) 
18 Ottoman Empire (1299/ 1301-1922) is the biggest Islamic multinational, multilingual empire ranging most of Southeast Europe, parts of Central Europe, Western Asia, parts of Eastern Europe and the Caucasus, North Africa and the Horn of Africa. It was inspired and sustained by Islamic ethos and institutions. Here among other practices, significant was that religious, ethnic, and geographical minorities were allowed to govern their own affairs to some extent. For details, Howard (2017); a brief account can be found: Bbc.com (2009).

${ }^{19}$ Djarwal b. Aws al-Hutay’a was an Arab poet who converted to Islam with his tribe during the reign of the caliphate of Abu Bakr, the first caliph of Islam. He was imprisoned by Umar ibn al-Khattab to whom he wrote the quoted verse. It is, therefore, al-Hutay’a sincerity regarding his poetry, for many, is questionable. Hisbrief life scratches and poetry could be found in Hawi (1970).

${ }^{20}$ Mawdudi narrates the word's multiple meanings and interpretations. However, it could be used to denote the situation that one became frightened of some impending mishap, and someone gave him the necessary shelter. See. Mawdudi, (2000, p. 10).

21 The meaning of the word varies in different contexts, some popular meanings could be one who brings up, rear, guardian, patron, owner or master. For details, see. Mawdudi (2000, p. 31).

22 This word too has several meanings, but generally means holding supremacy or surrendering oneself to his authority. For details, See Mawdudi 2000: 79.

${ }^{23}$ Mawdudi shows multiple use and meaning of Deen, simetmes to mean dominance of someone in authority or obedience from the part of the servant. See. Mawdudi (2000, p. 93).

${ }^{24}$ For the Quranic references I derived the translation of M. A. S. Abdel Haleem (Quran, 2004).

${ }^{25}$ Shirk means associating others with God in His exclusive qualities and attributes. 
${ }^{26}$ For Mawdudi, Taghoot is a person who rebels against God’s laws and make his own laws in the land.

${ }^{27}$ Zakat is an obligatory Islamic alms-giving practice and regarded as one of the five pillars of Islam (the others are declaration of faith, prayer, fasting in Ramadan and Hajj). For Zakat to be mandatory, Muslims must meet certain criteria of having wealth and there is established mechanism of calculating the amount of Zakat one has to offer. For a preliminary idea, see Zakat, (Islamichelp.org.uk, n.d.).

${ }^{28}$ Hudud punishment is a very controversial issue in Islamic jurisprudence. It is offered, among other causes, for unlawful sextual intercourse. The punishment ranges from amputation of hands to crucification to public lashing to public stoning to death. There are diverse views and practices on Hudud punishments. For details of its historical debates and practices, see Rabb (2015), chapter 3 and 4.

${ }^{29}$ Here making laws in Mawdudi’s interpretation does not mean human being's the absolute authority of law making, it rather means to arrive at some decisions employing ijtihad on the subjects those are not explicitly directed in Quran and Hadith.

30 Jahiliyyah in Quran has been used in different contexts. It generally means to the ignorance to God. It is mostly used to mean the barbarous practices of polytheists of pre-Islamic Arabs who were not cognizant to monolithic faiths. But Qutb imposes a radical meaning on the term. For Qutb, it is the "rule of humans by humans because it involves making some humans servants of others, rebelling against service to God, rejecting God's divinity (ulahiyya) and, in view of this rejection, ascribing divinity to some humans and serving them apart from God.” From this ground, Qutb rejects all man-made ideas such as secularism, nationalism, democracy etc. It is for him, any concept that goes beyond God's described path is Jahiliyya, therefore, for Muslims, is subject to rejection. For details of Qutb’s interpretation of the term, consult: (Sephard, 2003).

${ }^{31}$ It seems paradoxical in Mawdudi and Qutb’s thought. On the one hand, they argue for the creation of universaltransnational Muslim brotherhood, the sense of ummah, rejecting the ethnicity-based nationalism of modern nation 
states. On the other, they argue for an Islamic state which is territorial. They, however, did not shed light on how to reconcile the two.

${ }^{32}$ For details, see significant works arguing that other interpretations of sovereignty in Islam are possible. For example, Razek (2013) argues that Islam does not have deterministic form of governance and therefore, the door for multiple interpretations of Islamic ideas is always open. Ahmad (1958) based on few classical Islamic philosophers' ideas, shows that popular sovereignty to accept in Islam is possible.

${ }^{33}$ It should be noted that the sovereignty of ummah is not an entirely new concept. It has been in the discourse of Islamist political thought for long. The entire Salafiya movement of $19^{\text {th }}$ century Islam was argued for an Islamist sovereignty that could be compared to the sovereignty of ummah. Mohammad Abdhu to Rashid Rida to Tahtaw among others argued for in many capacities for people's sovereignty in Islam with God's reference. For the details of this lineage see Black 2011, also Tamimi 2007. Two key proponents of Mawdudi and Qutb too in a way argued for the sovereignty of ummah. But the contribution of Ghannouchi is that he more convincingly theorized and popularized this take of sovereignty with a historical exploration of Islamic traditions, texts and practices.

${ }^{34}$ There are vibrant debates against this claim of complete separation of temporal and spiritual in the Western political tradition as well that got momentum with the popularization of Carl Schmitt’s term "political theology.” By this concept he draws attention to the fact that a theological spirit underlies all seemingly modern political concepts such as “sovereignty, contract, state, etc." (Schmitt, 1985). In the present thesis I am not entering these debates as my attempt here is to look at how the already established popular sovereignty is debated in the modern Islamist political thought.

${ }^{35}$ Anthony Black in his book the History of Islamic Political Thought (2011) (in first chapter) offers an account of arguments in favor of Islam's inseparability from politics. For more details understanding, please see Hamid (2016, chapter one and two), (Cook, 2014), (Lewis, 1988). The entire arguments on divine sovereignty in Islam popularized with the arguments of Abu Ala Mawdudi and Syed Qutb base their arguments on this inseparability debate. 
${ }^{36}$ Ghannouchi did not coin the term he rather borrowed from his contemporary Islamic thinkers such as Mohammad Salim al Awwa, and Mohammad Amara who are among the major proponents of democracy in Islam and believe that Islam is separated from politics. Some of the relevant debates of them could be found: (El-Solh, 1993).

${ }^{37}$ Mohammad migrated to Medina in 622 named as Hijra with his followers when he was facing massive persecution in Mecca. He was invited to Medina by city leaders to settle disputes prevailed in the city between clans. Mohammad returned in Mecca after a victory over the city. For details of early times of Mohammad, see (Hinds, 1986 ) Hold and Lewis eds. (1977), particularly chapter two, p. 30-56.

${ }^{38}$ Mawdudi and Qutb’s thought on sovereignty centers on Quranic concept Tawhid, oneness of God where it is argued that politics and religion are inseparable.

39 The inference is that once an Islamic community is formed, the inherent Islamic nature of a community that is developed based on God's will, does not remain similar to the state of war as it was pre-Islamic Arab societies-the Ahd-i-Jahaliyat (the age of ignorance). I infer that Ghannouchi is discussion the contract in an Islamic community. However, during his discussion of the formation of the early Islamic state in Medina, the pre-Islamic societies' state of war is hinted in many ways what could be analogous to Ahmed's articulation of the state of nature in Arabia. For details, see: Ahmed (1942).

${ }^{40}$ Ghannouchi's civil state is a concept that goes against the assumptions of an Islamic state. While in an Islamic state, religion and politics are inseparable in Islam, in a civil state, the fundamental assumption is that religion would remain out of politics. The term became popularized after Ennahda and other secular parties drafted a reform agenda in 2005 when they came in a consensus that a civil state is the only feasible reality for future Tunisia. They envisioned a civil state as the basis of a democratic governance. After coming in power, Ennahda officially separated religion from politics and in an attempt to form a civil state. For details: (Ghannouchi, 2016; Ghannouchi, 2018; Ottaway, 2013). 
${ }^{41}$ The details of the process of al-masaliah and definitional and practical debates could be found, Opwis 2005; Sadek 2014: 8-9; Hallaq has elucidated Ash-Shatibi’s theory of al-masaliah with a comparison with significant advocates of it from which Ghannouchi is influenced, see Hallaq, 1997, P. 129-30, 179-90; March opposes Hallaq's take on al-masaliah and advocates al-Fasi's interpretations of it, for details: (March, 2015b).

${ }^{42}$ Negus was the Emperor of Ethiopia who lived during the early years of Islam who advised by Prophet to participate politically with a non-Islamic government, and Abdul Aziz was a Umayyad caliph who although did not able to approve Monarchy practiced there that was not in Islamic principles. However, he did not leave his responsibilities and could initiate some positive changes staying within the existing governance structure.

${ }^{43}$ It is to note that the comment is made based on March's recent lectures at Webster University and some other seminars both in the USA and outside. His forthcoming book's title is also "The Caliphate of Man: The Invention of Popular Sovereignty in Modern Islamic Thought.” So far, the available writings and lectures of March do not elucidate the details of his "invention of popular sovereign in Islamic thought” thesis. The forthgoing book might shed light on the issue.

${ }^{44}$ The details of debates between two groups of ulama could be found in (Metcalf, 1982), chapter 7.

${ }^{45}$ It seems paradoxical. One the one hand, Ghannouchi argues that individual has freedom to leave religion, one the other, he argues that a Muslim cannot compromise God's religious authority in any means. It could be inferred that Ghannouchi's argument is that if one remains in the faith of Islam he must submit to God in religious affairs, not the temporal-political affairs. But once he leaves faith, submission to God does not matter, at least in Ghannouchi's thought.

${ }^{46}$ The Boston Review debate on democracy in 2004 shows a fascinating account of challenges to democracy in Islam where the major scholars in the field such as Khaled Abou Fadl, Jeremy Waldron, John Esposito, Noah Feldman, Nader Hashemi, Muqtedar Khan, among others opined on the issue. For the debate see (Fadl, 2004). 